INTER NATIONAL MONETARY FUND
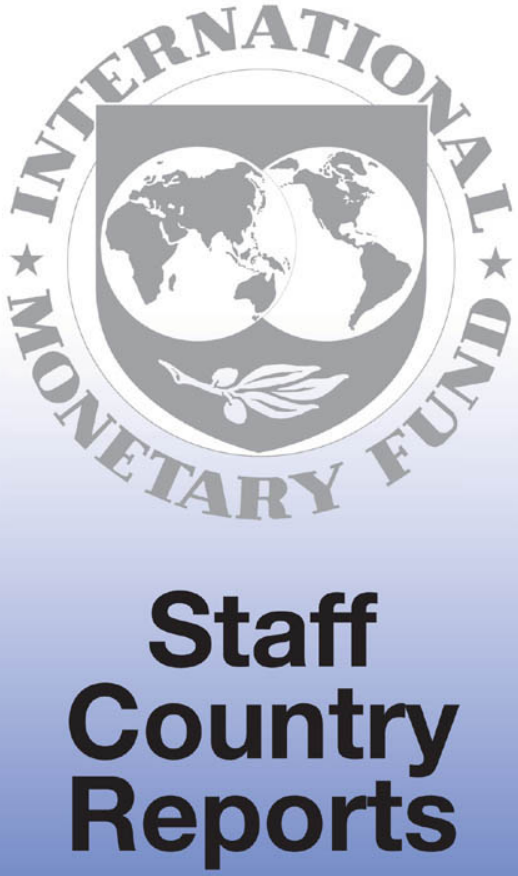


\section{Islamic Republic of Mauritania: Poverty Reduction Strategy Paper Progress Report}

Poverty Reduction Strategy Papers (PRSPs) are prepared by member countries in broad consultation with stakeholders and development partners, including the staffs of the World Bank and the IMF. Updated every three years with annual progress reports, they describe the country's macroeconomic, structural, and social policies in support of growth and poverty reduction, as well as associated external financing needs and major sources of financing. This country document for the Islamic Republic of Mauritania, dated June 2003, is being made available on the IMF website by agreement with the member country as a service to users of the IMF website.

To assist the IMF in evaluating the publication policy, reader comments are invited and may be sent by e-mail to publicationpolicy@imf.org.

Copies of this report are available to the public from

international Monetary Fund - Publication Services

$70019^{\text {th }}$ Street, N.W. $\bullet$ Washington, D.C. 20431

Telephone: (202) 623-7430 • Telefax: (202) 623-7201

E-mail: publicationsQimf.org - Internet: http://www,imf,org

Price: $\$ 15.00$ a copy

International Monetary Fund
Washington, D.C. 


\section{ISLAMIC REPUBLIC OF MAURITANIA}

\section{Honor - Brotherhood - Justice}

\section{REPORT ON IMPLEMENTATION OF THE POVERTY REDUCTION STRATEGY PAPER IN 2002}

JUNE 2003 


\section{LIST OF ABBREVIATIONS AND ACRONYMS}

AAAD

ADB

ADER

ADU

AMM

ANEPA

APROMI

APW

ASAP

BCM

$\mathrm{BE}$

BGR

BHU

BNT

CAMEC

CAPEC

CBD

CBS

$\mathrm{CCD}$

CCIA

$\mathrm{CCP}$

CDHLCPI

CEP

CFEPE

CFPF

CGEM

CMAP

CNC

CNRE

CNEOP

CNTS

CREN

CSA

CSED

DCL

DFI

DPP

DRASS

Arab Association for Agricultural Investment (Association arabe pour l'investissement agricole)

African Development Bank

Rural Electriftcation Development Agency (Agence pour le développement de l'électrification rurale\}

Urban Development Agency (Agence pour le développement urbain)

Association of Mayors of Mauritania (Association des matres de Mauritanie)

National Safe Drirking Water and Sanitation Agency (Agence nationale de l'eau potable et de ['assainissement)

Association of Microfinance Professionals and Operators (Association des professionnels et opérateurs de la micro-finance)

Access to potabie water

Agricuiture sector adjustment program

Central Bank of Mauritanio (Banque centrale de Mauritamie)

Basic education

Road Managernent Office (Bureau de gestion routière)

Basic health unit

National Transportation Office (Bureau national des transports)

Central Procurement Office (Centrale d'achats)

Popular Savings and Loan Association (Caisse populaire d'épargne et de crejdit)

Convention on Biological Diversity

Competitive bidding specifications

Convention to Combat Desertification

Chamber of Commerce, Industry, and Agriculture (Chambre de commerce, d'industrie et d'agriculture)

UDP Coordination Unit (Cellule de coordination du PDU)

Commission on Human Rights, Poverty Reduction, and Integration (Commissariat aux droits de l'homme, à la lutte contre la patureté ef à l'insertion)

Poverty Reduction Project Execution Unjt Cellule d'exécution du Projet de réduction de la pauvreté)

Preschool Teacher Trajning Center (Centre de formation des éducateurs de la petite enfance)

Center for the Training and Advancement of Women (Centre de formation et de promotion féminine)

General Confederation of Mauritanian Employers (Confédération générale des employeurs de Mauritonie)

Maurtanian Center for Policy Analysis (Centre Mauritanien d'Analyse de Politiques)

Community Nutrition Center (Centre de nutrition communatuaire)

National Water Resources Center (Centre national de ressources en eau)

National Center for Oceanographic and Fisheries Research (Centre national de recherche océanique et de pêche)

National Blood Transfusion Center (Centre national de transfusion sanguine)

Center for Recovery and Nutritional Education (Centre de récupération et d'éducation nutrittonnelle)

Food Security Commission (Commissariat à la sécurité alimentaire)

Strategic Framework for Combating Desertification (Cadre stratégique de lutte contre la désertification'

Local Government Directorate, MPT (Direction des collectivités locales du MIPT)

Basic importation right (drott foncier à l'importation)

Detailed preiminary project

Regional Health and Social Action Directorate Direction régionale de l'action sonitaite et sociale) 
DREF

DSPCM

EDF

EDS

EIB

EIG

EMEA

EMP

ENER

EPCV

FAO

FAP

GERM

GPP

HFAR

HIPC

FIVPR

HILI

IEC

LO

IMF

INAP

IR.F

KfW

LLDCs

MAED

MCE

MDG

MDRE

MEMAU

MEN

MET

MFIs

MICOs

MPT

MOUGHATAA

MPEM

MSAS

MSB

MTEF

NDB

NICT

NKC

OIE

OMVS

ONS

PAC
Regional Basic Education Directorate (Direction régionale de l'enseignement fondamental)

Offshore Inspection and Fisheries Surveillance Directorate (Direction de la Sarveillance des Pêches et du Contröle en Mer)

European Development Fund

Dernographic and social survey (Enquête démographique et sociale)

European Investment Bank

Economic interest group

Maurtanien livestock and agriculture survey (Enquête mauritanienne sur l'élevage et

l'agriculture')

Environmental management program

National Road Maintenance Enterprise (Entreprise nationale d'entretien routier)

Ongoing living conditions survey (Enquête permonente sur les conditions de vie)

Food and Agriculture Organization

Training Support Fund (Fonds d'Appui à la Formation)

Improve your business management (Girez mieux votre entreprise)

Petroleum Product Distributors Association (Groupement des distributeurs de Produits

Pétroliers)

Heal th facility access ratio

Heavily Indebted Poor Countries

HIV/AIDS prevalence ratio

Figh labor-intensiveness

Information-Education-Communication

International Labour Office

Head tax (Impót minimum forfaitaire)

Professional Training Support Institute (Institut d'Appui a la Formation Profassionnelle)

Tax on property income (Impôt sur le revenu foncier)

Kreditanstalt für Wiederaufbau (German cooperation agency)

Least developed countries

Ministry of Economic Affairs and Development Ministère des affaires économiques er du développement)

Expanded Exchange Market (Marché de Change Elargi)

Millenrium Development Goal

Ministry of Rural Development and Environment (Ministère du déveLoppement rural er de ('environmement)

Mauritantian Economic Model (Modèle de l'économie mauritanienne)

Ministry of National Education (Ministère de I'éducation nationale)

Ministry of Equipment and Transportation (Ministère de l'équipement et des transports) Microfinance institutions

West Asian Investment and Credit Unions (Mutuelles d'investissement du crédit oasien) Ministry of the Interior, Post, and Telecommunications Ministère de l'intérieur, des postes et telécommunications)

An administrative subdivision. Mauritania has 53 moughataas distributed among its 12 wilayas.

Ministry of Fisheries and Maritime Economy Ministère des pêches et de l'économie maritime)

Ministry of Health and Social Action (Ministère de la santé et de l'action sociale)

Microenterprise and small business

Medium-Term Expenditure Framework

Nouad-ibou

New information and communications technologies

Nouakchott

World Organisation for Animal Health (Organisation Internationale de I'Epizootie)

Organization for the Development of the Senegal River

National Statistics Office

Project to assist municipalities (Projet d'aide aux communes) 
PACAD Program to assist cooperatives in difficulty (Programme d'appui aux cooperatives en difficulté)

PADDEM Project to Support Deconcentration and Decentralization in Mauritania (Projet d'Appui à la Déconcentration el à la Décentralisation En Maurifanie)

PAFEM Project to support economic and financial administrations in Mauritania (Projet d"appui aux administrations économiques el financières en Mauritanie)

PAN/LCD Nationai Action Plan to Combat Desertification (Plan d'Action National de lutte contre la désertification)

PANE

PARP

National Environtnental Action Plan (Plan d'Action Nationale sur l'Environnement)

PASK Pliviale)

PCIME

PDLAEM

Progran to Combat Poverty in Aftout Sud and Karakoro Programme de lutte contre la paurreté dans ('Aftout Sud et ie Karakoro)

Integral coverage of childhood diseases (Prise en charge integrée des maladies de ['enfant)

PGFF

PGRNM

PGRNP

Integrated Program for the Development of Irrigated Agriculture in Mauritania (Programme de Développement Intégré d'Agriculture Irriguée en Mauritanie)

Refrigerant management plan (Flan de gestion des fluides frigorigènes)

Project for natural resource management in Mauritania (Projet de gestion des ressources naturelles en Mauritanie)

PGRPDE Project to manage pasturelands and develop livestock breeding (Projet de gestion des ressources pastorales et développement de l'élevage)

PIP

PNAN

P\}NBG

PNDSE

PRSP

Public investment program

National Nutrition Aotion Plan (Plan d'action national pour la nutrition)

National Good Governance Plan (Programme national de bonme gouvenance)

National Education Sector Development Progratn (Programme national de développement du secteur éducatif)

RAMSAR

RDF

RGPH

Poverty Reduction Strategy Paper (Cadre siratégique de lutte contre la pauvreté)

Convention on Wetlands (named after the city where the Convention was signed)

Regional development find

General population and housing census Recensement général de la population et de ithabitat)

ROSC

RPTES

SAMIN

SDAU

SECF

SME

SMI

SNDE

SNIM

SNS

SOCOGIM

Report on the Observance of Standards and Codes

Review of Policies, Strategies, and Programs of the Traditional Energy Sector

Arab Company for Inchiri Mines (Société Arabe des Mines de ('Inchirl)

Urban improvement and development schema (Schéma de développement et d'amenagement urbain)

Secretariat for the Status of Women (Secrétariat d'Etat à la condition fëminine)

Small and medium-size enterprises

Small and mediwn-size industry

National Water Company (Société Nationale de ('Eau)

National Inđustria: and Mining Company (Societé nationale industrielle et minière)

National security stoek (Srock national de sécurité)

SOMELEC

SONADER

SONELEC

SPOs

SPP

ST

TDW I

TOR

TFE

PT

UDP

Construction and Property Management Company (Société de construction et de gestion immoblière)

Mauritanian Electric Company (Société mauritanienne de l'électricité)

National Rural Development Company (Société notionale pour le développement nural)

National Electric Company (Société nationale de l'électricité)

Socioprofessional orgenizations

Summary preliminary project

Statistica] tax

Tetanus, diphtheria, whooping cough

Terms of Reference

Technical and professional education

Technical and professional training

Urban development program 


$\begin{array}{ll}\text { UHT } & \text { Ultra-high tension } \\ \text { UM } & \text { National currency unit (ouguiya) } \\ \text { UNCACEM } & \text { National Union of Savings and Loan Associations (Union Nationale des Caisses } \\ & \text { Agricoles de Crédit et d'Epargne de Mauritanie) } \\ \text { UNCTAD } & \text { United Nations Conference on Trade and Developrnent } \\ \text { VAT } & \text { Value-added tax } \\ \text { Wilaya } & \text { Administrative region. Mauritaria has } 13 \text { wilayas, plus the district of Nouakchott. } \\ \text { WTO } & \text { World Trade Organization }\end{array}$




\section{TABLE OF CONTENTS}

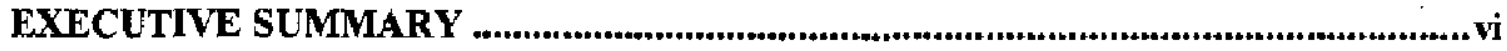

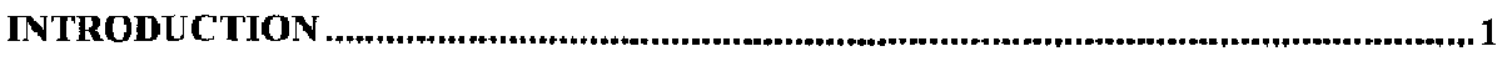

1. TAKING STOCK OF THE SECOND YEAR OF PRSP IMPLEMENTATION......2

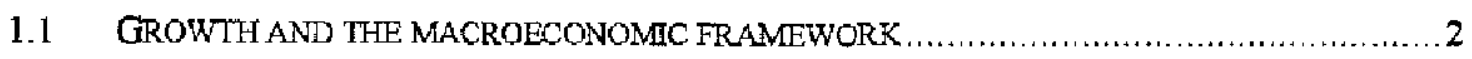

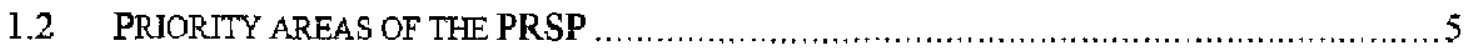

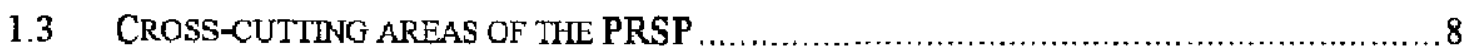

1.4 STRENGTHENING INSTTTUTIONAL CAPACTTEES AND GOVERNANCE $\ldots \ldots \ldots \ldots \ldots \ldots \ldots \ldots \ldots$

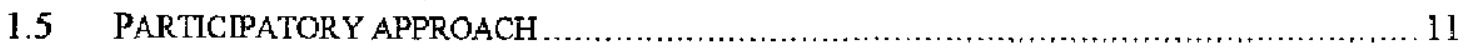

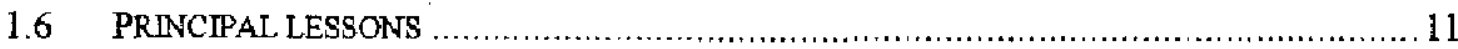

2. OUTLOOK FOR THE 2003-04 PERIOD........................................................14

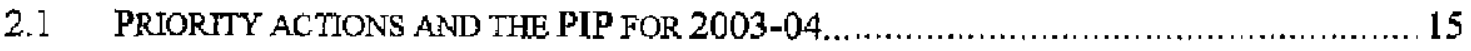

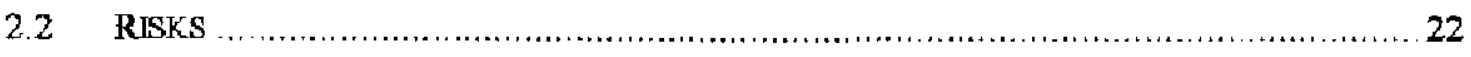

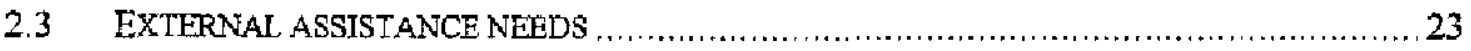

\section{ANNEXES}

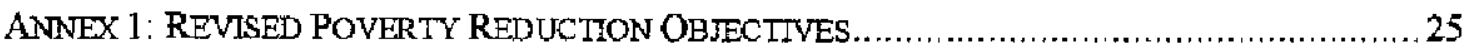

ANNEX 1 BIS: MONITORDNG INDICATORS FOR SHORT-FERM POVERTY REDUCTJON ............. 26

ANNEX 1 TER: COMPARISON OF PRSP OBJECTIVES AND

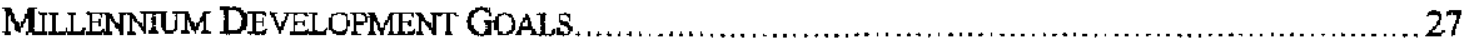

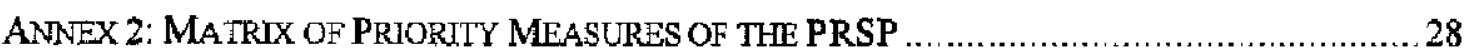

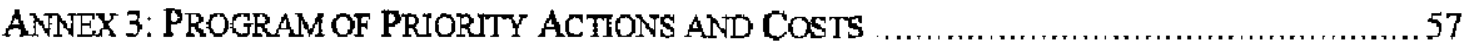

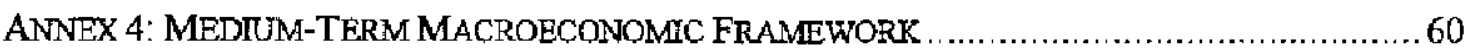

ANNEX 5: REVISED MEDIUM-TERM EXPENDIFURE FRAMEWORK FOR EDUCATION .............61

ANNEX 6: REVISED MEDIUM-TERM EXPENDITURE FRAMEWORK FOR HEALTH $\ldots \ldots \ldots \ldots \ldots \ldots .61$

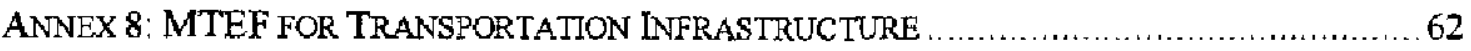

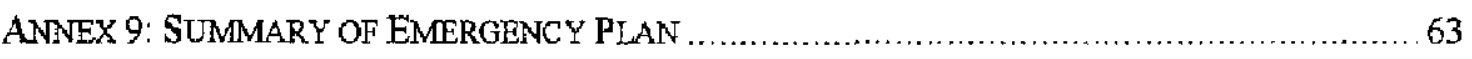




\section{EXECUTIVE SUMMARY}

1. The Poverty Reduction Strategy Paper, whose implementation has now reached the second year, has been the key instrument in Mauritania's economic, social, and institutional development policy. Accordingly, following the PRSP adoption in January 2001, a number of departments revised their strategies and adopted Medium-Term Expenditure Frameworks (MTEFs) which now enable them to align themselves with the objectives, orientations and action plan of the PRSP. This is particularly so in the areas of education, health, urban development, rural development, and transportation infrastructure. Preparation of a global MTEF and MTEFs for water resources, rural electrification, and fisheries, has now been initiated.

2. The efforts of stakeholders in the fight against poverty, whether in the private sector, civil society, or development partners, are geared towards achieving the objectives of the PRSP. This reflects, on the one hand, the government's determination to use the PRSP as a fundamental development policy tool and, on the other hand, the effective adoption of the PRSP by all national and external stakeholders.

3. Moreover, the reaching by Mautitania of the Completion Point under the Enhanced HIPC Initiative in June 2002, as well as the forgiveness of its debt vis-à-vis Paris Club creditors, demonstrates the determination of its development partners to support the PRSP implementation.

\section{Outconte of the second year of PRSP implementation}

4. The results of PRSP implementation in 2002 attest to the successful execution of most of the important actions planned (see Box 1) and the achievement of significant results in the priority areas.

5. The pursuit of policies to accelerate growth, maintain macroeconomic stability, and enhance the competitiveness of the economy have thus made it possible to attain an economic growth rate of about 3.3 percent, notwithstanding an unfavorable international economic climate, cold rainfall, and less total rainfall than customary. Annual inflation has been contained at 4 percent. Moreover, the budget surplus was 6.2 percent of GDP and the external current account (excluding official transfers) was in balance. Public expenditure rose significantly in the priority sectors (education, health, and targeted programs to combat poverty), from 8.0 percent of GDP in 2001 to 10.6 percent of GDP in 2002.

6. The policies aimed at anchoring growth in the economic environment of the poor, made it possible to reach out to benefit that group, particularly through: (i) targeted programs to combat poverty (see Box 2); (ii) programs to promote microfinance, with loans amounting to UM 2.5 billion in 2002 (more than 50 percent of which were from CAPECs) extended to 113,034 recipients, 49,936 of whom were rural, and a volume of mobilized saving which increased from UM 576 million in 2001 to UM 894 million in 2002; and (iii) literacy campaigns and professional training programs that served more than 5,000 persons.

7. Finally, the implementation of human resource development policies and the expansion of basic services have had encouraging results in the areas of: (i) education, where 
the rate of access to the first year of basic education rose from 97 percent in 2001 to 111 percent in 2002 and the disparities between access by boys and girls were virtually eliminated; (ii) health, where the rate of full three-dose DTC vaccination rose from 52 percent in 2001 to 70 percent in 2002 .

8. The participatory PRSP process was continued into 2002 and still fully irlvolves all stakeholders in combating poverty (administration, elected officials, civil society, private sector, and development parthers). This report was prepared on the basis of the work carried out by topic-based Technical Groups, and was subsequently enriched by the contributions of regional and national workshops. In addition, the CDHLCPI worked directly with the poor with a view to ensuring the involvement of the PRSP's beneficiary population and thereby securing its ownership of the effort.

\section{Major lessons learned}

9. The major lessons from two years of PRSP implementation relate to: (i) the relevance of its strategic orientations and the need to revise some of its objectives; (ii) the economy's vulnerability to exogenous shocks; (iii) the need to improve financial intermediation to unleash the private sector as the driving force behind economic growth; (iv) the rapid development of a national absorption capacity in line with to PRSP ambitions (v) the priority towards regionalizing the PRSP; and (vi) the need for further involving civil society organizations in the implementation of poverty reduction programs.

\section{Outlook for 2003-04}

10. The government is determined to press ahead with the implementation of policies and programs aimed at improving the living conditions of the people, consistent with the strategic orientations of the PRSP.

11. Emphasis will therefore be placed on continuing and intensifying the implementation of polices aimed at: (i) accelerating growth and preserving macroeconomic stability, in particular by implementing an action plan to enhance the competitiveness of the economy and develop the export sectors; (ii) anchoring growth in the economic environment of the poor, by implementing the UDP, rural development programs, the strategy for universal access to services, and targeted programs to combat poverty; (iii) developing human resources by implementing the PNDSE and the 2002-2004 MTEF for the health sector; and (iv) improving governance and enhancing institutional capacities, with implementation of the PNBG and the national strategy for improving public absorptive capacities.

12. The action plan for 2003-04 is supported by a Public Investment Program (PIP) in the amount of about UM 119 billion, or which UM 33.2 billion has yet to be mobilized.

\section{Risks}

13. Carrying out the PRSP continues to be confronted by the risks already identified in the first report during its implementation: (i) fluctuations in world markets; (ii) poor weather conditions; and (iii) weak institutional capacity. These risks are compounded by possible shortfalls in mobilizing the resources necessary for the intensified implementation of the priority actions for $2003-04$. 


\section{External assistance needs}

14. External assistance continues to be necessary in order to ensure the successful implementation of the PRSP. First, as noted above, it is necessary to rapidly mobilize the resources necessary to secure the full financing of the priority plan of actions for 2003-04. In addition, technical and financial assistance are essential for strengthening national capacities for designing, executing, and monitoring/evaluating policies to combat poverty.

\section{Bax 1: Principal Measures Taken in 2002, by PRSP Pillar}

Pillar 1: Accelerated and redistributive growth

- Adoption of an action plan to entance the competitiveness of the exonomy and develop the export sectors, and organization of a donors' roundtable;

- Tax relief for businesses; and

- Increase budget allocations for the social sectors and for the targeted programs to combat poverty (share of government budget increased to 10.6 percent of GDP, compared to 8.0 percent in 2001).

Pillas 2: Growth anchored in the economic sphere of the poor

- Targeted prograns to combat poverty: implementation by the CDHLCPI of targeted programs to combat poverty in the major poverty pockets in rural areas and in the periphery of the major cities (see Box 2).

- Urban development: (i) initiation of the ambitious Urban Development Program (UDP), including the launching of the preparatory work for the Welcome Center for households to be resettied; and (ii) preparation of an MTEF covering the 2002-04 period.

- Rurd development: (i) submission to the goverment of a draft implementing decree for the Farming Code; (ii) drafting of a livestock development policy letter; (iii) implementation of the antual programs of the PGRNP, PDIAIM, Oasis Project, and the Control Center; and (iv) continuation of the program to support agricultural food industries with marketing national production, with special emphasis on market research and identifying facilities to finance exports.

- Cross-cutting measures for income and job creation: (i) preparation of strategies to promote microfinance and microenterpises; (ii) continued support for microfinance; and (iii) the pursuit of professional lraining programs and programs to integrate higher education graduates in search of their first jobs.

Pillar 3: Developing human resources and expanding access to basic services

- Education: (i) recruitment of 454 new instuaters; (ii) completion of new infrastructure (1,880 classrooms); (iii) renovation of programs; (jv) continuous training of staff, (v) availability of instructional tools; and (vi) introduction of a new organization chart for the MEN.

- Heahh and nutrition: (i) construction and equipment of 54 health posts and rehabilitation of 7 regional hospitals, (ii) establishment of the CAMEC and the CNTS, (iii) revision of cost recovery provisions to irtprove financial access to health cere on the part of the poorest; (iv) adoption of strategic plans for certain programs (AIDS, Malaria, RS); and ( $v$ ) establishment of a sizable number of CNCs and revitalization of the CRENs.

- Water resources: (i) preparation of a draft Water Code; (ii) continuation of work to extend the APWs of Nouadhibou and 9 other secondary cities; (iii) initiation of the safe drinking water supply project for the city of Kiffa; and (iv) continued guidance of the Aftout Es-Saheli project.

- Universal access: Establishment and start-up of activities of the Agency to Fromote Universal Access to Services.

Pillar 4 : Improving governance and strengthening capacities

- Adoption of the Budget Execution Law for fiscal year 2001;

- Formulation of the National Good Governance Program (PNBG);

- Implementation of measures to strengthen capacities for public investment programming, execution, amd monitoring/evaluation;

- Effective startup of the work of the Mauritanian Center for Policy Analysis (CMAP) serving the administration, elected officials, and civil society;

- Implementation of a program to enharce the professionalism of 30 Mauritarian NGOs. 


\section{INTRODUCTION}

1. Mauritania has just completed the second year of implementation of its first PRSP. Adopted in January 2001, the PRSP is the key instrument in the country's economic, social, and institutional development policies. This status took concrete form in the adoption of the PRSP by all stakeholders in the fight against poverty, as the framework for mobilizing and harmonizing all efforts. Hence, the MTEFs for education, health, urban development, and transportation infrastructure reflect the alignment of these sectors' priorities to the objectives and ambitions of the PRSP. They will soon be complemented by MTEFs for rural development, water resources, and rural electrification, as well as a global MTEF.

2. Furthermore, the fact that the development partners' interventions are aligned with the strategic orientations of the PRSP, denotes its effective adoption by the international community and the effectiveness of the coordination role played by the government.

3. A stock-taking of the second year of PRSP implementation reveals a number of positive changes, despite an unfavorable context in 2002 characterized by poor weather conditions (rainfall shortage, cold rains early in the year) and an international economic climate marked by slack demand for Mauritanian products, resulting in reduced fishery products and iron ore exports.

4. The priority actions carried out in 2002 focused on: (i) the pursuit of economic and financial policies aimed at preserving macroeconomic stability and enhancing the competitiveness of the economy; (ii) bolstering the policies focusing growth on the economic environments involving the poor, by starting the ambitions Urban Development Program (UDP), continuing the rural development programs and the target programs to combat poverty, and preparing strategies for the development of microfinance and microenterprise; (iii) developing human resources by implementing the PNDSE, launching the campaign to promote books and reading, and implementing the action plan for the health sector; and (iv) improving governance and strengthening institutional capacities, with the formulation of the PNBG and the launching of a review of the problems associated with capacity building in the context of the PRSP.

5. There was also a major turning point in 2002: Mauritania reached the completion point under the enhanced HIPC Initiative for debt reduction. Subsequently, the creditor countries in the Paris Club cancelled all of Mauritania's debt. This makes it possible to envisage the mobilization of additional resources for financing the PRSP, which will be a decisive factor in its success.

6. The initial lessons drawn from a review of execution, midway through the first action plan of the PRSP, make it possible to introduce corrective measures so as to achieve the medium-term objectives. In this regard, the government is resolved to accelerate the implementation of priority actions for the period 2003-04, with a Public Investment Program (PIP) in the amount of almost UM 119 billion, of which UM 33 billion must still be lined up.

7. The purpose of this report is to take stock of PRSP execution in 2002 and to assess the outlook for 2003-04. The report is the outgrowth of wide-ranging consultations involving all stakeholders (administration, elected officials, civil society, private sector, and development partners) in the framework of the participatory process of the PRSP. Indeed, a first draft was drawn up in light of the reports from topic-based Technical Groups, then modified following regional workshops, and finally validated in the course of national meetings.

8. The report is organized as follows: a brief overview of PRSP implementation in 2002 and the major lessons learned are presented, followed by the outlook for the 2003-04 period, including 
the identification of priority actions, risks, and requirements for external assistance. Finally, annexes set forth; (i) the revised objectives of the PRSP; (ii) the matrix for monitoring the priority measures; (iii) the cost of the priority action plan; (iv) the medium-term macroeconomic framework; and (v) the MTEFs for certain priority areas.

\section{TAKING STOCK OF THE SECOND YEAR OF PRSP IMPLEMENTATION}

9. The monitoring of the implementation of the priority actions undertaken during the second year of PRSP implementation was the subject of a broadly participatory process, involving all the relevant stakeholders engaged in poverty reduction (government, elected officials, civil society, private sector, development partners). This process took place at various levels: in the work of technical committees, thematic groups, regional workshops, and national meetings. The consultative process now makes it possible to assess the execution of the measures called for in 2002 .

10. It thus appears that Mauritania made significant progress in the implementation of the PRSP. Efforts were concentrated particularly on: (i) implementing measures aimed at accelerating growth driven by the private sector and stimulated by the development of economic and social infrastructures; (ii) carrying out major programs in the priority sectors of the PRSP; and (iii) introducing of actions to build capacity and strengthen governance.

11. Experience also shows that achieving the objectives of the PRSP will require addressing a number of structural and institutional constraints, including: (i) the lack of diversification of the economy and its vulnerability to exogenous shocks; and (ii) the inadequacy of national capacities for program development, implementation, and monitoring/evaluation.

12. The major actions carried out in 2002 and the obstacles encountered are presented as follows: (i) growth and macroeconomic framework; (ii) the priority areas of the PRSP; (iii) crosscutting areas of the PRSP; and (iv) building capacity and strengthening governance. Subsequently, the report presents the review of the principal milestones of the participatory process, and the summary of the preliminary lessons drawn from two years of PRSP implementation.

\section{I Growth and the macroeconomic framework}

\section{Macroeconomic framework}

15. Economic growth reached 3.3 percent in 2002 , despite an unfavorable economic climate characterized by cold rains at the start of the year, rainfall shortage, and a reduction in fishery products and iron ore exports. The sectors directly affected by this economic climate (agriculture, livestock, mining, and fisheries) accounted overall for a negative contribution of 1.7 percent to growth in 2002. The principal sources of growth were the manufacturing sectors other than fisheries, construction and public works, services, and public administration. Sound fiscal and monetary policies made it possible to stimulate domestic demand while containing average annual inflation at 4 percent, although prices were rising faster toward the end of the year owing to imported inflation and cereal shortages. The cumulative financial compensation from the EU under the fisheries agreement for 2001 and 2002, was reflected in a budget surplus of 6.2 percent of GDP and a balanced extemal current account (excluding official transfers), thus promoting the accumulation of domestic assets and foreign exchange reserves, which cover nearly 8.7 months of imports. 
16. Concerning public finances, the

measures taken included: (i) continuation of tax system simplification and tax reduction with the implementation of the reforms included in the 2002 Budget Law and the adoption of new measures in the 2003 Budget Law (reduction in the business profits tax (BIC) to 20 percent, reform of the tax on wages and salaries (ITS)); (ii) broadening of the tax base through the elimination of

Prtarity Expenditure (Education, Health, and Poverty Reduction] as \% of GDP

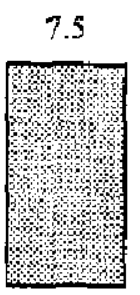

1998

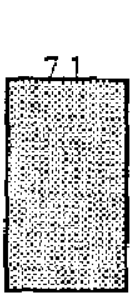

1999

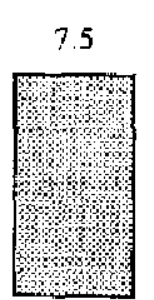

2000

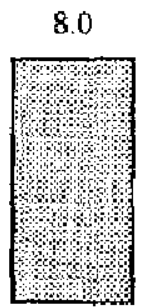

2001
10.6

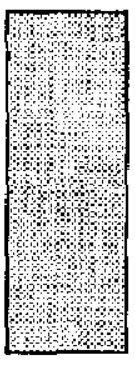

2002 exemptions and the strengthening of tax administrations, making it pessible to offset the tax relief measures (fiscal pressure remained thus constant); (iii) improved budget programming with the preparation of new sectoral MTEFs; and (v) increase allocation of public expenditure destined to poverty reduction, made possible by reaching the completion point under the enhanced HIPC Initiative Consequently, the share in the government's budget of the social sectors and the povertyreducing programs, increased from 8.0 percent of GDP in 2001 to 10.6 percent of GDP in 2002 .

17. External sector. The government adopted a priority plan of actions aimed at enhancing the competitiveness of the economy and its integration into world trade (see Box 4), and organized a round table to mobilize the required financing. In addition, measures have been taken to improve the functioning of the exchange market (monitoring committee and $\mathrm{BCM}$ intervention on the Expanded Exchange Market (MCE), financial intermediation, repatriation of export receipts, etc.) while preserving its external competitiveness. Concerning external debt, in 2002 Mauritania reached the completion point under the enhanced HIPC Initiative and obtained debt relief of about US\$304 million from Paris Club creditors.

18. In the mining sector, the standard mining convention has been adopted, seven detailed maps have been produced, and several new exploration permits have been granted. Consequently, 15 operators holding a total of 76 exploration permits are now involved in the area of prospecting, an indicator of the sector's growing attractiveness. Moreover, SNTM continued its investments aimed at increasing its production capacity and improving its productivity. Finally, SAMN was sold to a foreign investor, now preparing to resume production at the Akjoujt mine. In the oil and natural gas sector, four off-shore drillings have been performed, confirming the discovery of oil fields (reserves estimated at 200 million barrels) and natural gas fields ( 30 billion cubic meters).

19. The major actions taken in the fisheries sector concemed were: (i) the adoption of the decree implementing the fisheries code; (ii) the preparation of resource development plans; (iii) the strengthening of surveillance activities; (iv) the holding of the 5th IMROP working party on evaluating stocks and fisheries; (v) the continued implementation of the training program for the sector; (vi) the completion of a project to enhance the value of small pelagic fish in the neighborhoods on the periphery of Nouakchott, benefiting the poorest; (vii) the training of 250 women in value enhancement and marketing; (viii) the extension of the non-industrial fishing port of Nouadhibou (NDB); (ix) the undertaking of studies on the removal of stray animals and on port infrastructures (the Tarit pelagic fishing port, extension of the NDB port); and ( $x$ ) the construction of a pipeline for transporting fuel between the refinery and the NDB port.

20. A number of important actions were taken in the area of tourism: (i) creation of an office for promoting the sector; (ii) preparation of a development strategy for the sector; (iii) promotion of 
the tourism activity through participation in fairs and expositions; and (iv) the development of basic infrastructure contributing to broadening the number of tourist destinations.

\section{Enhancing private sector dynamism}

21. The major measures carried out in this area include: (i) the simplification of the tax system and tax relief for businesses (lowering the BIC rate to 25 percent and subsequently to 20 percent under the 2003 Budget Law, carrying deficits forward for 5 years, full deductibility of the head tax (IMF), uniform rate of 0.5 percent for the registration duty, elimination of the proportional business license duty, extending VAT reimbursement to imports of capital goods, etc.); (ii) adoption of the texts implementing the investment code, mobilization of extemal resources for the preparation of implementing provisions for the commercial code, and dialogue with social stakeholders on the preliminary draft labor code; (iii) conduct of a study on economic regulation and its impact on growth and poverty reduction; (iv) imparting new dynamism to the CCIA and mobilizing financing for the introduction of a Commercial Information Center in order to increase access to extemal markets and improve the terms of trade; ( $v$ ) strengthening the government-private sector partnership through the Consultation Committee and organization of regional workshops to promote private investment in Mauritania, with the conduct of prior studies on the promising niches in each region; and (vi) establishment of the technical structures of the Multisectoral Authority and the acquisition of frequency management equipment.

\section{Growth-supporting Infrastructure}

22. In transport, the implementation of PRSP actions has resulted in: (i) more rapid investment in road infrastructure (completion of the rehabilitation of two segments of the Espoir road, initiation of work on the Nouakchott-Nouadhibou road, and initiation of other projects such as the Rosso-Bodhe road) and the allocation of significant resources to road maintenance (UM 1.6 billion in 2002 and UM 2 billion in 2003); and (ii) the start of work to expand the airport at Néma, and the launching of studies on the construction of a new international airport in Nouakchott. Also in 2002, an MTEF was prepared for transport infrastructure (see Annex 8) and for revitalizing the Road Management Office (BGR). With respect to ports, the studies on the creation of a coastal fishing port at Tanit and the improvement of a pelagic fishing port at Nouadhibou were finalized.

23. In the energy sector, the major actions undertaken include: (i) promulgation of the law on. oil and natural gas; (ii) the selection, following a competitive bidding process, of an international operator for providing the country with petroleum products following the cancellation of the agreement on the operation of the Nouadhibou refinery; (iii) continued work on the Project to Secure the Supply of Petroleum Products, which will make it possible to develop a new berth in a protected area, a new storage area, and pipes for transferring fuel and butane gas to the depots; (iv) postponement of the privatization of SOMELEC, as the competitive bidding pracess was not successful owing to the low level of a sole bid lodged, and continued monitoring of the international climate in this sector with a view to re-launching the process; $(v)$ connecting Nouakchott with the Manantali Power Plant; and (vi) development of an investment plan for rural electrification.

24. On what concerns new information and communications technologies (NICTs), activities in 2002 included: (i) the implementation of the NICT development strategy; (ii) the completion of several information technology training and information activities, enhancing the visibility of Mauritania on the web; and (iii) the launching-of projects with a pronounced NICT focus. In telecommunications, coverage of the national territory has been improved by: (i) connecting all regional capitals to the cellular system, as well-as several Moughataas; (ii) tending the landine system to 6 new Moughataas; and (iii) taking actions aimed at improving service quality. 


\subsection{Priority areas of the PRSP}

\section{Rural development}

25. In livestock, the main actions taken were as follows: (i) preparation of a draft decree for the implementation of the Faming Code, following broad consultation among its users, and including a mechanism for enhancing the awareness of local governments and socio-professionat organizations (SPOs) inspired to the Sharia and local communications mechanisms and cultures; (ii) drafting of a livestock development policy letter with priority action plan emphasizing animal health measures; (iii) improvement in collective resource management as a measure to mitigate the effects of drought and natural disasters; (iv) support for the development of priority subsectors (cattle, leather and hides, red meat, family poultry farming, milk) and animal health (OIE procedure for declaring countries free of rinderpest disease); and (v) the effective startup of the Noaukchott Slaughterhouse Company.

26. In agriculture, the main actions taken include: (i) the implementation of the annual programs of the PGRNP, PDIAIM, project OASIS, PACAD, and the Control Center; (ii) the continued pursuit of the program supporting food crop industries and the marketing of national produce, with particular emphasis on the search for markets and facilities for export; (iii) the continued training of small producers in agricultural diversification; (iv) the consolidation of agricultural credit in order to promote irrigated agriculture and the agricultural diversification program; ( $v$ ) the implementation of the program to equip production zones through the creation of a sub-sector for providing plant health treatment products, establishing seed security stocks, building 100 stores, and introducing plows to 400 villages; and (vi) the protection of crops against disease and predators (sesamia, Acrididae, birds).

27. In 2002, tangeted programs to combat poverty were implemented in the major poverty pockets in the country. For the most part, these activities were conducted by the CDHLCPI and benefited all the wilayas, in the context of regional programs of priority actions for combating poverty (see Box 2).

\section{Urban development}

28. The second year of PRSP execution coincides with the first year of implementation of the Urban Development Program (UDP). The year 2002 saw the beginning of activities of the new structures (CCP and ADU) in charge of urban development, and the preparation of an MTEF for the sector covering the 2002-04 period (see Annex 7). Concerning the coordination and monitoring of UDP execution, an evaluation of the necessary measures to strengthen the institutional framework and strengthen the capacities of intervening structures was carried out, with a view to optimizing the projected investments. In this respect, technical assistance teams are being hired to belp the CCCP, the DCL, and the AMM. The program to improve living conditions in the shanty towns in Nouakchott has begun, and the setting up of the welcome center for households to be resettled is underway.

\section{Education}

29. In the education sector, PRSP implementation in 2002 has contributed to bring about positive changes in the sector's indicators. In particular: (i) the rate of access to the first year of schooling increased from 97 percent to 111 percent, thanks notably to the completion of a program to construct 900 classrooms, hire 464 instructors, and implement a law making the schooling of children mandatory; (ii) quality improvements were sought through the free distribution of essential textbooks to all children in school, whether public or private; the delivery of 81,400 
student desks and 10,000 pedagogical kits for teachers; continued efforts to renew programs that have made it possible to train 6,000 instructors and school directors in new programs, as well as the introduction of incentive measures for teachers assigned to disadvantaged areas; (iii) the restructuring and professional enhancement of higher education teaching have been initiated, and the purchase of hardware for the Internet rooms of the various institutions and of 5,000 library books are in progress; (iv) the strengthening of capacities in structures responsible for preschool children was started, with the realization of a training session for trainers at CFEPE; (v) literacy campaigns have been continued and measures have been taken to build bridges between informal and formal education; (vi) pedagogical and administrative management tools have been developed and made available to the various stakeholders; and (vii) management and steering instruments for the educational system have been put in place, including a geographical information system and a model for optimizing teacher assignments.

30. In addition, 2002 was the year of the effective launching of the national campaign to promote books and reading throughout the entire country. The objective of this program is to improve everyone's access to knowledge in general, and to techniques that make it possible to improve productivity and living conditions in particular. This initiative saw the mobilization of the government, private sector, civil society organizations and private citizens. This concerted effort has resulted in the following actions: (i) the allocation to the Book and Reading Promotion Fund of resources from all parties involved; (ii) the beginning of the construction of 53 libraries in Moughataa capitals; and (iii) the beginning of the distribution of books covering various topics and areas. 


\section{Box 2: Targeted programs to combat poverty}

The implementation of targeted programs to combat poverty in the periphery of urban areas and the major poverty packets in rural areas is aimed at directly contributing to the reduction of poverty and inequality. These programs, which complement the actions canied out by the sectoral departments, are characterized by: (i) specific targeting of the poorest and most vulnerable groups and aneas; (ii) the search for an immediate impact on improving the living conditions of the affected populations; and (iii) a participatory approach that fully izvolves administrative authorities, local elected officials, civil society, and the beneficiaries themselves. The execution of these programs is generally delegated to municipalities, specialized agencies, NGOs, etc.

The major programs carried out in 2002 are:

\section{In urban areas:}

I1 The "Twize" program to revitalize solidarity chamels, which targets people living in the periphery of urban areas who have extremely limited economic capacities, pHecarious housing conditions, and poor access to credit. It has four components: housing mictofinance, communify activities, and training. This program made it possible to build 1,730 housing units and grant 896 loans (79 percent of them to women), with a recovery rate of 99.7 percent, which contributed to significant inprovement in the living condjtions and incomes of the target populations.

I.2 In 2002 the program to combat exchusion benefited more than 600 persons (handicapped, orphans, beggars, etc.) in the city of Nouakchott. Its components are: (i) providing food and sanitation services to the individuals concersed; (ii) education, literacy programs, professional training; and (iii) support for income-generating activities.

\section{In rural areas:}

II 1 The "Taumze" program for the regeneration of small subsistence-level livestock raising, which targets rural populations with extremely limited economic capacities who do not own their own herds. Its objectives are to contribute to food security, improve nutritional conditions, and generate incomes. The program made it possible to distribute 20,000 units (ammul growth rate of 49.1 percent in Aftout).

Il2 The rural infrastructure program, whose primary objective is to overcome the shortage of socioeconomic infrastructures in rural areas. It focuses on the following issues: (i) safe trinking water: pastoral wells, tube wells, water supply facilities (more than I50 works); (ii) improvements to agricultural water supply: dikes, minidikes, runoff deflection harriers, dams (almost 50 works); (iii) access to the interior: mountain passes, fords, crossing wotks, nual roads; (jv) livestock farming support: pastoral centers; and (v) socioeducational irffastructure.

U3 The support program for cooperatives in dificulty (PACAD), which benefits disadrantaged village-1evel communities along the river (wilayas of Trarza, Brakna, Gorgol, and Guidimagha). It makes it possible to solve the problems resulting from the government's divestiture in the early 1990s, in particular the deterioration of land improvernents and the problems obtaining agricultural credit. It has three components: (i) rehabilitation of improved lands (more than 1,000 hectares rehabilitated); (ii) the financing of seasonal crop credit; and (iii) the organization and supervision of farmer groups. In 2002, suppont was extended to 25 cooperatives.

\section{Program to support income-generating activities:}

The program to support income-generating activities (EGAs) is aimed at improving the incomes of beneficiaries and providing basic commodities to the people. In 2002, the wilayas of Hodh Echargui, Assaba, Brakna, TirisZemmow, and Inchiri benefited fin this program with the establishment of: (i) 625 IGAs in urtan areas (crafts, small trade, etc.); and (ii) 132 other activities in rural areas (village-level shops, grain mills, etc. ), which benefited 40,000 per'sons in rural areas.

\section{Assaciated programs:}

IV. 1 The professional training and functional literacy programs benefited 740 persons (of whom 500 live in rual areas) receiving professional training in various fields (small urban trades, anisnal health, agricultural techniques, and management of cooperatives), while 25,000 persons took part in functional literacy training.

W.2 The CDHLCPI has Iecently established regional coordination offices responsible for: (i) participating in identifyirg PRIPs, (ii) providing complete information on programs and approaches to combat poverty and on the national human rights policy, (iii) monitoring program execution; and (iv) participating in the effective regionalization of the PRSP. 


\section{Health}

31. Implementation of the PRSP in 2002 made it possible to carry out the following activities: (i) strengthening decentralization by increasing financial allocations to the regions (between 200 percent and 400 percent) and by hiring 13 accounting officers and 11 statisticians; (ii) direct recruitment of 289 health officials and employees, and training in progress for 12 pediatricians, 12 obstetrics and gynecology specialists, and 390 paramedicals; (iii) construction and equipping of 54 health posts; (iv) imparting new dynamism to regional hospitals (rehabilitation of seven hospitals, equipment of eight others now in progress, construction and equipment of the Nouadhibou hospital, training of senior physicians, and assigniment of eight surgeons; (v) purchase of a large amount of vehicles and equipment (blood banks, computer hardware, etc.); (vi) establishment of CAMEC and the CNTS; (vii) revision of the cost recovery provisions ensuring that some medications and consumable supplies will be free, the establishment of a special fund for covering the costs of indigents in order to ensure the financial accessibility of the poorest to essential health care; (viii) conducting two pilot experiments on reducing the impact of health expenditure on the poorest in Nouakchott (obstetric flat fee) and in the two Hodhs (indigence project); (ix) preparation and implementation of the contracting approach with NGOs; $(x)$ adoption of strategic plans for certain programs (AIDS, malaria), establishment of the National Council for Combating AIDS chaired by the Prime Minister, and beginning the evaluation of the multisectoral program; and (xi) continued implementation of the NUTRICOM project through the introduction of a sizable number of CNCs and the revitalization of the CRENs.

\section{Safe drinking water and sanitation}

32. The following actions have been taken in the dninking water and sanitation sector: (i) preparation of a draft Water Code which is expected to be promulgated soon; (ii) continuing work to extend the APW for Nouadhibou and 9 other secondary cities; (iii) startup of an ambitious project to provide safe drinking water to the city of Kiffa; and (iv) continuing efforts on villagelevel and pastoral water and sanitation systems, such as the Rural Water Resource Program in the southeast, the Espoir Water Project, and the Program for the Nouakchott-Nouadhibou-Tiris area The preparation of the Aftout Es-Saheli project has continued and it is envisaged that the necessary funding will be mobilized by end-2003.

\subsection{Cross-cutting areas of the PRSP}

33. Important measures have been taken in the area of employment: (i) the preliminary draft Labor Code has been approved by the National Labor Council and is now being reviewed by the government; (ii) a study has been conducted on the improvement of the treatment of employmentrelated issues; and (iii) the Employment Information System (SIME) has been improved through the updating of the component "Training Institutions" file and the establishment of the new component "Employers in the Structured Sector."

34. In the area of micro-enterprise promotion, a strategy and action plan have been prepared and in the process of being approved. The artisanal craft sector has received particular attention and a artisanal code has been finalized and endorsed by the relevant stakeholders, government and Parliament. Other activities have been taken which benefit craftsmen in various areas, including training, information, and credit. Furthermore, the CDHLCPI has introduced programs on incomegenerating activities (IGA) in five wilayas throughout the country, making it possible to finance 625 activities aimed at 8,248 recipients regrouped into 628 cooperatives, and 132 activities aimed at 48 Community Development Associations (ADCs) grouping together 28,800 people. 
35. In micro-finance: (i) a strategy and action plan were finalized in April 2002 and are currently in the process of being approved; (ii) the outstanding balance of loans granted rose to UM 2,464 million in 2002 (of which over 50 percent is from CAPECs) to 113,034 recipients, of which 49,936 are in rural areas; (iii) the volume of saving mobilized increased from UM 576 mitlion in 2001 to UM 894 million in 2002; an ethics code and a guide for creating microfinance institutions (MFIs) have been prepared; (v) the CDHLCPI has supported 14 MFIs by means of an operating subsidy (UM 12 million), the granting of UM 180 million in loans, and making 63 university graduates available; and (vi) several training sessions have been organized (APROMI, CEP, etc).

36. In the area of professional training, an ambitious reform program was launched in 2002 under the PNDSE, with the introduction of the steering mechanism for technical and professional training (TPT) by creating the INAP and the FAP. In addition, 730 people have benefited from qualifying training programs financed by the CDHLCPI, including 500 on small trades through mobile units in five wilayas and 230 unskilled youths on small urban trades (electrical, plumbing, carpentry, etc.) in 5 cities in the country. Two new public training institutions (the CFPP of Tidjikja and Ailoun) were also inaugurated in 2002

37. The program on integration of jobless graduates has made it possible to integrate 1,229 graduates, 60 through financing microprojects, 63 in the MFIs, and the remainder in public administration and CDHLCPI projects. In addition, the window services made available by the CDHLCPI in the form of a one-stop shop for registering and orienting graduates have continued to operate in 2002.

38. Efforts for the advancement of women were continued in 2002 through: (i) launching of the process of re-updating the strategy for the advancement of women; (ii) the performance of several support activities for women's cooperatives through qualifying training and management training (nonindustrial fishing, GERME), credit (MFI organization and training); (iii) the strengthening of CFPFs; and (iv) dissemination of the Personnel Status Code through information and public awareness campaigns.

39. Concerning combating exclusion, actions related to the insertion of marginalized groups, in particular through pursuit of the program to combat begging, the undertaking of a study on a "orphanhood program" in Noaukchott's shanty towns, and the development of a social protection strategy at the national level.

40. Important actions have been taken in the area of food security concerning: (i) the prevention and management of food crisis situations through the operation of a Food Security Observatory responsible for gathering, processing, and distributing dati on the country's food security; (ii) the establishment and management of a National Security Stock; (iii) the establishment of a mechanism for humanitarian and emergency action responsible for funding, supervising, or coordinating appropriate interventions in the event of a structural or short-term food shortage; (iv) the definition of programs or microprojects in the food security area; and (v) the identification, monitoring, and evaluation of the micro-efforts envisaged or undertaken in this area.

41. As for universal access to basic services, the last 12 months of PRSP implementation were characterized by: (i) the establishment of the organisms of the Agency responsible for this mission, and the preparation of an ambitious program of multiyear actions, and the manual of universal access procedures; (ii) the preparation of an investment plan for rural electrification; and (iii) the launching of projects to improve water supply and the provision of electricity and telecommunications in twenty localities throughout the national territory. 
42. For the environment the actions carried out involved: (i) endorsement of the strategy and national action program on Biodiversity and on Combating Desertification, and finalization and presentation to the Conference of Parties of the initial national report on climate changes; (ii) the census of the bird population in rain-fed areas; (iii) systematization of environmental impact statements for all programs and projects; (iv) implementation of the process of harmonizing national legislation and regulations with the international conventions ratified by Mauritania, and their adaptation to Sharia and local customs; and (v) preparation of the second national report on climate change and the report on national biodiversity inventory.

43. Conceming forestry and the protection of nature, the actions taken included: (i) the preparation of a master plan for firewood and charcoal supply of major urban centers; (ii) the establishment of plantings over 10,500 hectares coupled with seeding by air in the Northern parts of Trarza and Brakna, as well as in Tagant; and (iii) the maintenance of the firebreak over a linear distance of 21,000 kilometers.

\subsection{Strengthening institutional capacities and governance}

44. The actions carried out in the areas of consolidation of the rule of law included: (i) training magistrates; (ii) creating a website for the Chancellery and providing it with computer equipment; (iii) laying the first stone for the Nouadhibou Palace; (iv) equipping the courts of Nouakchott and Kiffa; ( $v$ ) organizing consultation days on the development of an action plan for promoting and protecting human rights, with the establishment of a steering committee for this program; and (vi) training activities relating to Human Rights.

45. In the area of strengthening capacities of the government, the following actions have been taken: (i) dissemination of the provisional results of the RGPH; (ii) the completion of five studies on public administration in the context of the preparatory phase of the PNBG; (iii) restructuring of the MEN; (iv) organization of a forum on poverty monitoring indicators; (v) startup of the introduction of a monitoring and evaluation system for CDHLCPI programs; (vi) methodological work on the general census of agriculture and livestock; and (vii) introduction of the CMAP.

46. In the area of public resource management, the principal actions taken in 2002 involved: (i) the conduct of studies on the public finance system (ROSC and CFAA); (ii) the launching of the computerization of expenditures on goods and services; (iii) completion of an audit of the expenditure financed by HIPC resources in 2001 and ongoing dialogue with partners on monitoring the implementation of actions financed by these resources; and (iv) adoption of the final budget execution law for the 2001 budget.

47. The execution of public investment projects has improved significantly in recent years. This improvement in absorptive capacity is largely the result of the continuing implementation of measures, aimed at strengthening the management capacities of public administration in general and enhancing performance of public investment programming, execution, and monitoring/evaluation. These measures related primarily to:

- The preparation of the MTEF for use as the basis for allocating resources in certain sectors (health, education, transportation, rural development, and urban development); a global MTEF is now being finalized and will be used in preparing the 2004 Budget Law;

- The application of the new Government Procurement Code, which allows for more rapid execution of public investment projects;

- The intensification of training activities for project managers; 
- The introduction of monitoring/evaluation structures in the major spending departments (MEN, MSAS, MDRE, MET) and increase in the number of portfolio reviews with the principal donors and lenders.

48. The major actions taken in respect of decentralization are: (i) delegation of the MIPT's supervisory powers to the walis and hakems in order to enhance decentralization and deconcentration; (ii) preparation of a circular on the functioning of municipal administration; (iii) preparation of a report on the decentralization and good govemance strategy; (iv) publication of a municipal information joumal, El Belediya; (v) reform of the accounting and financial nomenclature used by municipalities; (vi) startup of the UDP, completion of the PADDEM, and implementation of KfW 3; (vii) a significant increase in FRD; and (viii) launching of the study on regionalization.

49. In the area of building capacity among civil society, the priority actions carried out are: (i) promulgation of Decree 2002-030 on the procedure for authorizing development associations; (ii) establishment of the Consultative Commission on Authorizing Development Associations; (iii) implementation of a training plan for 30 national NGOs on technical and practical issues; and (iv) drafting of the legal status of the cyber forum.

\subsection{Participatory approach}

50. The mechanisms adopted since April 2000 for the preparation and monitoring/evaluation of the PRSP continues to involve all the stakeholders in poverty reduction (administration, elected officials, civil society, private sector, and donors and lenders). Accordingly, this report was prepared on the basis of the work carried out by the Technical Thematic Groups and was the subject of consultation and validation at regional workshops and national meetings (see Box 3)

51. In addition, with a view to improving the participatory process, the CDHLCPI in 2002 engaged in direct consultation with the poor. These efforts constitute an important stage in strengthening the global process of consultation on the PRSP. They are aimed at: (i) broadening the consultation process for the PRSP, integrating the views of the public, particularly the poor and vulnerable groups; (ii) promoting the creation of communication spaces and dialogue for citizens, contributing to attitude change; and (iii) fostering an environment conducive to exchange and consultation, with a view to boosting the ownership of the PRSP.

\subsection{Principal lessons}

52. The principal lessons drawn from the two years of implementation of the poverty reduction strategy relate to: (i) the relevance of the strategic orientations of the PRSP, but also the need to revise some of its objectives; (ii) the economy's vulnerability to exogenous shocks; (iii) the need to improve financial intermediation in order to enable the private sector to serve as the main engine of growth; (iv) the importance of rapidly developing capacities for managing the economy and executing public expenditure programs, according to the ambitions of the PRSP; (v) the priority of regionalizing the PRSP along with enhancing the decentralization and de-concentration of resources; (vi) the urgency of putting in place a territorial development policy that enhances the supply of basic services (according to the 2000 RGPH, 88 percent of the localities in the country have populations of 500 or less); and (vii) the need to involve civil society organizations more in the implementation of programs to combat poverty.

53. The second year of PRSP implementation also shed light on the need to improve and intensify the participatory approach toward formulation, implementation, and monitoring of the 
PRSP, so as to strengthen commitment and the national consensus in favor of the PRSP and promote participation by the poor and making the most of their social capital.

54. Finally, additional work on the main characteristics and deteminants of poverty, carried out on the basis of data collected in 2000 (see Box 4), indicate that:

- The poor tend to move towards areas where poverty is decreasing, thereby offsetting the gains made in reducing (the incidence of) poverty in these areas. It would therefore be advisable to intensify and accelerate the execution of policies and programs aimed at keeping the population in its own original regions, as part of a harmonious territorial development logic.

- The rate of reduction in inequality (Gini), which contributed to the relatively fast decline in the incidence of poverty during the periad 1990-1996, has slowed down significantly between 1996-2000, thereby dampening the effects of growth on poverty reduction during this period. In a context where economic growth has yet to reach the desired pace, this phenomenon calls for the implementation of policies and programs aimed at reducing inequality, by anchoring growth in the economic enviromment of the poor and boosting human resource development. 


\section{Box 3: Consensus-Building for PRSP Implementation in 2002}

The process of participation, dialogue and consensus-building regarding the implementation of the PRSP was conducted through the ongoing efforts of the thematic technical groups and consensus-building committees, and by holding annual events, such as inter-regional workshops and national sessions. The purpose of this process is to: (i) achieve broad consensus among all stakeholders on the assessment of the second year of implementation of the PRSP; (ii) hear proposals and recommendations for a better and clearer articulation of the outlook for 2003-2004; and (iii) strengthen the participatory approach to the PRSP. Central and local governments and central and regional government technical units took part in these everts as did senalors and nembers of congress, mayors, the private sector, NGOs, socio-professional orgenizations, and the media.

\section{General comments}

Participants welcome the institutionalization of the inter-regional workshops organized for consensus building, which are meant to provide a form for exchanges and communication that would reinforce the partnership associated with inplementation of the PRSP. Notwithstanding their satisfaction with the efforts undertaken to combet poyerty, participants realize that the process of PRSP regionalization now under way will largely determine the effectiveness and impact of the overall strategy. Just as they did in respect of the 2001 review, participants insisted on the presentation of assessments by region, to enable regional stakeholders to judge the assessment on the basis of a knowledge of their regions and their local concerns.

\section{Broad concerns}

An overview of these various workshops shows that the major concerns of the participants are about: (j) regionalizing the PRSP, which must begin as soon as possible; (ii) deepening and strengthening decentralization; (jii) naking local stakeholders responsible for the design and execution of poverty reduction programs and projects; (iv) developing livestock rearing and promoting rural economic activity; (v) defining methodologies and intervention criteria to be used in poverty reduction programs for better priority targeting of vilnerable socioeconomic groups and areas; (vi) striving to increase efficiency in public expenditure; (vii) targeting woment and promoting women's activities; (viii) improving in the drinkjing water supply; (ix) using information and communications as a vehicle and condition of participation; and (x) continuing to promote the participatory approach.

\section{Rooting growth in the areas of economic activity in which the poor are engaged}

Regarding rural development, participants point out that: (i) priority must be given to the livestock sector, in light of its role and potential in reducing poverty; (ii) natural resources must be well managed in terms of the movement of cattle; (iii) small farmers must be supported and agrarian reform effectively implemented to give these farmers access to land ownership; (iv) local production must be protected and supported to enhance its competitiveness; (v) a strategy to protect productive infrastructure must be put in place; and (vi) a poverty rediction project needs to be set up in Aftout Nord and an integrated development project implemented for the palm plantations.

In terms of urban development, while participants welcome the launching of the Urban Development Frogram (PDU), they recommend: (i) extension of the CDHLCPI's "Twize" program to the regional capitals; (ii) combating disorderly settlement; (iii) promotion of income generating activities in peri-urban areas; and (iv) effective involvement of civil society in the implementation of urban policies and in the management of social infrastructure.

\section{Human resource development and access to basic social services}

In the area of education, participants recommend: (i) equipping schools with educationai materials; (ii) promoting bilinguatism in the schools; (iii) supporting the communes in performing their role in education; and (iv) implementing systems destgned to ectucate nomadic children.

Regarding health, the recommendations focus ofl: (i) exparding the network of regional hospitals and increasing their staffing; (ii) providing all health facilities with medical equipment and equipment maintenance; (iii) expanding and developing community nutrition prograns.

Concerning water, the proposal is to implement a communications strategy for better water management, continue the policy of reducing the cost of water, particularly for the poor, and create regional laboratories for water quality control, and capacity building for regional waterworks brigades.

\section{Governance and capacity building}

The main recommendations made in these areas are: (i) continue the program for training jwiges; (ii) strictly apply the principhe of proper sompensation; (iij) generate piblic awareness about the rule of law, create regional committees to promote human rights; (iv) connect the regional government authorities to the Internet; ( $v$ ) strengthen the control of public resource mathgement; (vi) creafe regional struetures to monitor and assess public expenditure; (vii) intensify capacitybuilding programs for civil society organizations; and (viii) effectively imptement the decentralization policy set out in the PRSP. 


\section{Box 4: Poverty Breakdown and Poverty determinants}

\section{Special breakdown of poverty:}

The spatial breakdown shows that the ceclime in poverty in 2000 is attributable for the most part to reductions in every zone (assuming constant population). However, this positive effect is attenuaied by the negative inpact of the population shift from one zone to another. The poputation tends to move toward areas where poverty is most significantly on the wane. Without this negative population effect, the reduction in the incidence of poverty would have been 4.7 percent instead of the 3.3 percent actualiy observed.

\section{Contribution of growth and redistribution:}

A breakdown into a growth effect and an inequality effect shows that the improvement in the status of the poor in 2000 as compared to 1996 is attributable mostly to growth (measured by the growth in average expenditure). It appears, according to this breakdown, that regardless of the residential environment, growth clearly contributes to poverty reduction, whereas inequality causes the poverty level to become worse. At the national level, slightly less than 30 ptrcent of the growth effects have been wiped out by the increase in inequality, while in urban areas the negative effects of inequality exceed 30 percent of the growth effects. These results indicate that the poverty reduction approach in Mauritamia between 1990 and 1996 is different from that between 1996 and 2000. During the first period, the reduction in poverty is traceable mostly to the reduction in inequality, even though growth did have a positive effect, while for the $1996-2000$ period the poverty redurtion is attributable entirely to the growth effect, white inequality played a rather negative role.

\section{Breakdown of inequality:}

The breakdown by zone (urban vs. rural) shows that inequality within groups represents 84,2 percent of total inequality. Moreover, analysis of total inequality indicates that even though inequality is more significant in rural areas, it is urban areas that contribute the most to it (43.4 percent of inequality is due to inequality in urban areas, as compared to 40.9 percent int rural areas). This same breakdown for the 1996 data shows that the inequality within each zone is worse, while the inequality of one versus the other is less (the inequaity between zones declined from 20.7 percent in 1996 to 15.8 percent in 2000). The breakdown by major ecological areas indicates that the weight of intra-group inequality is 82.6 percent and that Rural Other accounts for the greatest contribution to inequality (28.7 percent), followed by Nouakchott (24.8 percent), meaning that 53.5 percent of the inequality stems from inequality within these two settings. Moreover, these two areas by themselves account for about 65 percent of the inter-group inequality.

\section{Determinants of poverty:}

An econametric model where the dependent variable is per capita expenditure for 2000 has been estimated separately for the nural and urban environments. The results of this model make it possible to observe that in urban areas, the level of education of the head of household has a positive impact on the household's standard of living, contrany to household size for which there is a negative correlation. Moreover, in the urban setting, the status of the head of household's occupation has an influence on the household's standard of living: wage earners in the public sector fare the best.

In rural areas, the negative effect of household size is quite clear, and as regards the status of the head of household's occupation, it is found that there is a better standard of living for wage eamers in the private sector and a clear disadvantage for independent farmers as compared to wage eamers in the public sector.

\section{OUTLOOK FOR THE 2003-04 PERIOD}

55. In view of the lessons drawn from two years of PRSP implementation and from the risk analysis, it is considered necessary to: (i) revise the objectives for 2004; and (ii) redefine the priority actions whereby the objectives can be achieved.

56. The revised PRSP objectives for 2004 are: (i) reduction in the incidence of poverty to 41.3 percent in 2004, taking account of the increased pace of per capita GDP growth and of the increase in poverty reduction expenditure (basic infrastructure, social services, and safety nets); (ii) increase in the enrollment ratio to 90 percent; (iii) a decline in child mortality from 135 to 128 (per 1,000 live births) between 2000 and 2004 and in the malnutrition rate for children under 5 
from 32 percent to 20 percent over the same period; and (iv) improvement in the rate of access to a safe drinking water system to 45 percent by 2004 .

\subsection{Priority actions and the PIP for 2003-04}

57. To achieve these objectives, the firtal phase of implementation of the PRSP will be marked by continued intensification of efforts, consistent with the strategic focuses of the PRSP, with a view to: (i) achieving sustained economic growth anchored in the economic environment of the poor; (ii) developing human resources and extending access to basic services; and (iii) strengthening institutional capacities and enhancing governance. In addition, 2003 will feature the implementation of an emergency program aimed at benefiting the victims of the poor weather conditions.

\section{Acceleration of economic growth}

58. Accelerated economic growth will be sought in particular by: (i) the pursuit of fiscal and monetary policies aimed at stimulating investment and improving productivity while maintaining macroeconomic stability; (ii) implementation of the action plan for enhancing the competitiveness of the economy and its trade integration (see Box 5), and maximizing the growth potential of the export sectors (agriculture, livestock, fisheries, tourism, mining, and oil and natural gas); (iii) promoting the private sector; and (iv) the development of growth-supporting infrastructures.

59. In the area of macroeconomic policies, the government will pursue: (i) tax reforms to eliminate distortions, improve equity and reduce transaction costs, broaden the tax base, and bolster collections; (ii) increased public expenditure, in particular expenditure aimed at poverty reduction and infrastructure development, by improving efficiency and equity of expenditure allocation through the preparation of a global MTEF that ensures consistency with the macroeconomic framework and the priorities of the PRSP, as well as revitalizing domestic demand; (iii) strengthened external debt management with a view to ensuring long-term sustainability, through the search for external financing of investment expenditure on concessional terms and the formalization of creditor participation in the HIPC Initiative; and (iv) monetary and exchange policies aimed at accelerating private investment, maintaining price stability, and boosting the external competitiveness of the economy.

60. These efforts will be complemented by specific measures to promote the private sector by: (i) strengthening competition (regulatory framework, observance of competition, regulation of the transportation and oil and natural gas sectors, etc.); (ii) consolidating the legal reform; (iii) improving the regulatory framework by the adoption of implementation texts for the commercial code, and implementation of the recommendations of the study on economic regulation, in particular those concerning the simplification and quality improvement of regulations, with the conduct of ex post impact analysis and convergence with the countries of the UMA and ECOWAS; (iv) simplifying the tax system and providing tax relief with respect to productive activities; (v) preparing and implementing a financial sector development strategy; (vi) adopting a new labor code; (vii) implementing measures to facilitate trade; (viii) introducing crosscutting measures such as enterprise upgrading, standardization and quality control, and trade information; and (ix) continuing the state-private sector consultation effort and public awareness campaigns on business opportunities in the interior (see Box 5). 


\section{Box 5: Competitiveness and commerclal integration}

On April 10,2002, the govermment adopted a priority action plan aimed at improving the competitiveness of the national economy and its integration into international trade. This action plan consists of four packages of measures focusing on:

- Improvement of the competitiveness of the econony by pursuing efforts aimed at simplifying the tax system and providing tox relief for enterprises, improving access to credit and reducing real interest rates, improving and effectively implementing trade regulations and competitiveness regulation and reducing the transaction costs associated with govermment and the courts, lowering production factor costs by stimulating competition in the transportation and telecommunications sectors, and developing the transportation, energy, NITC, and safe drinking water infrastructures;

- Facilitation of trade by establishing a committee for consultation between customs and the private sector piloted at the ministerial leve1, adapting the national regulations to the multilateral legal framework and simplifying procedures, adopting the electronic document interchange (EDI) system and introducing greater selectivity in inspections, broadening the use of the ASYCUDA system and building the capacities of the customs administration (organization, resources, training, incentives, ethics code, etc.);

- Institutional support for increasing trade, with a strengthening of the major institutions responsible for export promotion and the negotiation of trade agreements, the effective establishment of export promotion entities (National Tourism Office, Fisheries Product Promotion Center), the evaluation and implementation of a standardization and quality control program focused on a priority basis on the export sectors, and creation of a trade information center; and

- Suppost for policies to develop the export sectors aimed at stimulating the sustainable growth of these sactors, improving their productivity and competitiveness, and enhancing the international market access their products enjoys.

To mobilize the financing and technical assistance necessary for canying out the measures included in the action plan and not covered by programs currently under way, on November 17-18, 2002, the goverument organized a roundtable which gathered together most of the country's development partners. The overall financing of the portfolio or projects comesponding to these measures amounts to US $\$ 1,686,527$, of which US\$1,843,032 will be provided by the Mauritanian Government and US\$9,843,495 is expected to be mobilized in the months ahead, in that the development partners showed a keen interest in the projects presented at last November's roundtable. During the 2003-04 period, the government is resolved to continue pursuing and advancing these reforms, which should have a significant impact on accelerating growth and reducing poverty.

61. Finally, growth potential will be maximized by: (i) implementing the rural development programs (see below); (ii) improving fisheries resource management and the integration of the fisheries sector with the economy through the development of processing infrastructures and units, training human resources, and strengthening the quality management, promotion, and marketing functions; (iii) continuing projects to expand the production capacities of SNIM and improve its productivity; (iv) accelerating investment in the mining sector (prospecting, takeover of Akjoujt mines, gold exploitation) and the oil and natural gas sector (exploration, production test on reserves discovered, possible exploitation) stimulated by the business environment and by the international economic climate; (v) developing the tourism sector thanks to stability in the country, the introduction of an institutional and regulatory environment that serves as an incentive, ecological and cultural diversity, and the completion of new infrastructures, in particular the NouakchottNouadhibou road and the expansion of the Nema airport; and (vi) the dynamism of the construction and public works sector and the transportation sector, with the implementation of the Urban Development Program and the infrastructure expansion that will have a positive long-term impact on growth by improving factor mobility through an integration of local markets and improved access to extemal markets.

-62. In the area of transportation infrastructure, the actions set forth in the MTEF will be implemented: (i) construction of the Rooso-Boghe and Kaédi-M'bout-Selibaby roads; (ii) completion of the construction of the Aioun-Nioro road to Mali and the Nouakchott- 
Nouadhibou road in order to ensure Mauritanía's enhanced integration into its regional space; (iii) expansion of the Nouadhibou port, construction of a pelagic fishing port at Nouadhibou and the Tanit port; and (iv) construction of the Nouakchott airport. In addition, measures will be introduced to strengthen the state-private sector partnership in financing and managing this sector. Competition in the transportation sector will be increased in order to reduce costs and improve service quality. Particular attention will be devoted to infrastructure maintenance, with increased resource allocations and the introduction of appropriate management instruments.

63. Regarding energy, actions will focus on the following: (i) electrification of the valley starting from Manantali; (ii) preparation and implementation of the MTEF for rural electrification; (iii) construction of infrastructures for enhancing the security of oil supplies; and (iv) strengthening the regulation of the sector with the establishment of the National Oil and Natural Gas Commission. With regard to the NICTs, the government intends to continue implementing its strategy and promoting the development of infrastructure and services.

\section{Box 6: Government and private sector consultation}

The drive to make the private sector the primary engine of economic growth has prompted the public authorities to irltroduce gradually, over more than a decacte, a series of economic, institutional and legislative reforms aimed at improving the business environment and promoting private investment.

It this framework, a National Committee for Government/Private Sector Consultation (CNCESP) was established in 1996 to create a permanent mechanism for consultation between the govemment and private agents on the various isslies of interest as regards to the development of the private sector.

In 2002, new dynamism was imparted to this mecharism by revamping the composition of the CNCESP to ensure better representation of economic agents, and by the establishmerst of a permanent and autonomous Secretariat responsible for organizing and monitoring the consultation process.

Each year, an indicative consultation program is drawn up and used, following adoption by the CNCESP, as the basis for dialogue between the govenment and private sector representatives.

Carrying out the programs for 2000-01 and 2002 resulted in major recommendations, which have been implemented, as regards to simplification of the tax system and tax relief for enterprises and imptoving the system of private investment incentives (new Investment Code promulgated in Januery 2002). Other no less important recommendations have been implemented in the areas of trade, tourism, transportation, construction and public works, and fisheries.

In accoriance with the guidelines of the PRSP, the government is resolved to consolidate and advance its consultation with the private sector so as to guarantee the complete success of Mauritania's economic and social policies.

To this end, the indicative consultation programs for 2003 and 2004 will address the various aspects of private investment promotion, particularly in the sectors with sigaificant potential, and the govemment will ensure that the recommendations adopted by the CNCESP will be implemented.

\section{Anchoring growth in the economic environment of the poor}

64. The government will continue to promote the anchoring of growth in the economic environment of the poor by introducing targeted projects and integrated development programs in urban and rural areas, as well as through cross-cutting measures supporting microenterprise and job creation. Furthermore, with a view to ensure the effectiveness and long-term viability of public investment, a study will be conducted on the development of a master plan for territorial development.

65. The implementation of the longuterm strategy for rural development will be intensified by: (i) enhancement of the growth potential of the livestock sector through the strengthening of the 
institutional and regulatory environment, the improvement of animal health, infrastructure expansion, integration of the sector into the economy, the development of derivative products, and the promotion of the export-oriented sub-sectors; (ii) the expansion of irrigated agriculture, thanks in particular to improved access to production factors (land tenure reform, transfer of collective perimeters, consolidation of agricultural credit, etc.) and inputs, infrastructure development (rehabilitation of perimeters, roads-tracks and improved vehicle access, energy, processing center, refrigerated storage, etc.), the supply of training, research, and extension services, and the promotion of diversification of export-oriented production; and (iii) improvement in the rate of agricultural growth in the other ecological zones through the development of rural infrastructures, increased access to factors, and their productivity supported by the supply of extension services. Implementation of this strategy will be supported by the execution of several projects (Phase II of the PGRNP, PDLAIM, Project on Raising/Managing migratory livestock).

66. In the area of urban development, the government will implement targeted programs aimed at strengthening the equipment of towns and cities for supporting economic activity and reducing poverty in urban settings. These programs will also make it possible to strengthen an integrated approach to community development articulated around the following components: (i) the promotion of decent social housing; (ii) support for income-generating activities; (iii) strengthening the capacities of target groups; and (iv) supplying grassroots urban infrastructures. This orientation will be supported by actions to improve the environmental framework through the organized collection and removal of household waste. The outlook for the years ahead as regards urban development depends upon the highly sizable investment effort to be made by the government in favor of strengthening equipment in the regional capitals and the gradual integration of the shanty towns in Nouakchott and Nouadhibou. This orientation should result in gradually slowing the mounting inequalities between cities and regions, through coordinated infervention by the government, the inunicipalities, the private sector (formal and informal), and civil society (NGOs, associations, neighborhood organizations, etc.).

67. The targeted programs to combat poverty will be consolidated, intensified, and spread to cover all areas of intensive poverty and the poorest/most vulnerable population groups in the country. In this context, a number of programs are planned: (i) the program to promote stonecutting in the context of heavily labor-intensive works (paving of mountain passes for providing road access to isolated areas, urban sidewalks, and the construction of stone housing and the stone lining of agricultural water works); (ii) integrated interventions by the PASK in the moughataas of Ould Yengé (Guidimagha), Karkossa (Assaba) and M'bout (Gorgol); (iii) continuation of the PACAD in the wilayas of Trarza, Brakna, Gorgol, and Guidimagha; (iv) continuation of the "Toumze" project in the wilayas of Inchiri, Trarza, Brakna, and Gorgol; (v) continuation of the rural infrastructure program (trails, dams, dikes, etc.); and (vi) initiation of the program to enhance the value of the Kankossa pool through the development of forage and vegetable crops. Implementation of these programs will be supported by the establishment in 2003 of nine regional coordination offices for the CDHLCPI, covering the national territory in its entirety.

68. Cross-cutting measures will also be undertaken in order to support accelerated growth in the environment of the poor, with: (i) implementation of strategies to develop microfinance and microenterprise; (ii) carrying out large-scale programs of professional training and literacy training; (iii) continuation of programs for the placement of school graduates; and (iv) intensification of the support for income-generating activities for women and the improvement of their productivity.

69. Finally, social protection measures will continue to be put in place, with: (i) strengthening the program for the insertion of vulnerable social groups (the handicapped, beggars, orphans, rison populations, etc.); (ii) monitoring food deficit situations with the introduction of appropriate rapid warning mechanisms and the development of the mapping of vulnerability areas; and (iii) 
implementation of the entergency program for 2003 benefiting drought victims. This program, with an estimated cost of UM 10.6 billion, will cover in particular the distribution of food for humans and livestock, the health and nutritional situation of populations at risk, support for livestock breeding (animal health, implementation of the "Toumze" project, distribution of subproducts from livestock), support for agriculture (completion of agricultural water works, offseason production, and rainfed zones), and the establishment of an AGR benefiting cooperatives and ADCs (see Annex 9).

\section{Development of human resources and expansion of basic services}

70. The development of human resources and the expansion of basic services continue to be the principal pillars of PRSP implementation. Indeed, the extent of the progress made in these areas will serve as a way of measuring the efficiency and effectiveness of the programs implemented as well as the impact of resource utilization. In this regard, appropriate monitoring/evaluation indicators will be defined for the areas considered and monitored systematically.

71. In education, particular emphasis will be placed on: (i) the implementation of measures to improve the retention rate; (ii) continuing the process of establishing the support fund for TPT; (iii) development of scientific and technological education and the promotion of research; (iv) enhancing the professionalism and diversifying the supply of training; and (v) improving the quality and internal efficiency of education. In addition, the efforts to promote books and reading will be intensified and broadened to cover the entire country.

72. In the health sector and in keeping with the programs included in the MTEF, the following activities will be carried out: (i) preparation of a set of policy documents (sector policy letter, human resources policy, hospital policy, medication policy) aimed at framing future action more satisfactorily; (ii) continuing the activities already begun with respect to the construction and outfitting of health structures, personnel training facilities, and structures for enhancing public awareness; (iii) consolidation of priority programs (Expanded Vaccination Program (PEV), Fight against Malaria and AIDS); (iv) strengthened decentralization with a view to enhancing the functionality of regional and departmental structures (hospitals in the largest moughataas); (v) widespread application of the successful experiences in the context of mutual systems; (vi) extension of the community nutrition centers and CREN; (vii) implementation of the emergency nutrition plan drawn up in 2002; and (viii) improved implementation capacities through the training of administrative personnel in the sector in the areas of programming, financial management, and monitoring and evaluation, with the active involvement of civil society (contracting) and communities (health committees).

73. In the area of water resources, the government will continue and intensify the implementation of ambitious programs aimed at equipping underserved areas and strengthening existing infrastructures to meet increased demand. This includes in particular: (i) completion of the Kiffa APW project; (ii) completion of the APWS for the semi-urban centers in the wilayas of Guidimagha and Gorgol; (iii) the completion of village-level water programs; and (iv) the introduction of water infrastructures in the context of the targeted programs to combat poverty. In addition, financing will be sought for the completion of the Aftout Es-Sahli Project and the rehabilitation of the Nouakchott APW network. Studies will also be conducted for establishing the legislative, regulatory, and standards framework and for the definition of a national sanitation strategy. Finally, an MTEF will be prepared for the sector.

74. Conceming universal access to basic services, the agency entrusted with this mission will seek to implement its multiyear action program through the private sector. This program will make it possible to expand the private supply of infrastructure services, in particular in urban, semi- 
urban, and peri-urban settings, and in so doing to contribute to the integration of domestic markets, expansion of the productive base, and reduced vulnerability in these areas. In tandem, the ADER will continue its efforts in the area of rural electrification.

\section{Governance and capacity building}

75. Successful implementation of the PRSP requires good governance and the strengthening of the institutional and human capacities of the national stakeholders in combating poverty (administration, parliament, local governments, private sector, and civil society). In this regard, the government will adopt and initiate the implementation of the National Good Governance Program (PNBG) in 2003. Furthermore, a capacity building strategy will be finalized

76. On the rule of law, the implementation of the PNBG will be reflected in: (i) strengthening Parliament's capacities through training, improvements in internal organization, and the development of the information system; (ii) continued strengthening of the judicial sector through the training of magistrates and court aides, the provision of infrastructure and human and material resources, the establishment of a legal observatory, imparting new dynamism to the judicial inspectorate, and the dissemination of information; (iii) the promotion of human rights through strengthened consultation, training, and public awareness campaigns; and (iv) consolidation of the democratic process, continuing the spirit of the recent municipal and legislative elections that were saluted by the international community for their transparency.

77. On what concerns public administration, studies will be conducted with a view to preparing a new reform of the public sector, seeking to adapt it efficiently to its missions, bring it closer to users, simplify procedures, introduce quality management, and establish a human resource management system that provides sound performance incentives (qualifications-based recruitment, wages, continuous training, merit-based promotions). The following actions have already been planned: (i) the reorganization of departments on the basis of audits; (ii) strengthened capacities in the strategic areas of economic management, programming and monitoring/evaluation, through the implementation of several programs; and (iii) development of an administrative network using fiber optic technology. Moreover, in order to take advantage of the relaxation of budgetary constraints resulting from debt relief, improving absorptive capacity will continue to be one of the government's key concerns (see Box 6). 


\section{Box 7: Improving absorptive capacity}

During the period $2003-04$, the government will continue and deepen the reforms amed at improving absorptive capacity by implementing a cohesive package of measures aimed at simultaneously:

- Strengthening design and programming capzcities;

- Stretrgthering project execution capacities;

- Strengthening capacities for monitoring and evaluation;

- Harmonizing the procedures of conors and lenders;

- Strengthering private sector capacities.

As regards strengthening design and programming capacities, the measures planned deal primarily with: (i) preparation of the global MTEF and sectord MTEFs; (ii) improving the quality of the PIP by more effective selection of public investment on the basis of multiyear programning; (iii) stjengthening planning structures, and (iv) improving intersectoral coordination

Improving project execution capacities will mostly entail measures to: (i) revise the Procurement Code and disseminate the new regulations among the officials involved in govemment procurement; (ii) improve project management by writing procedural manuals and annual work programs with budgets; (iii) systematize portfolio reviews with most donors and lenders and conduct supervision missions more regulatly; (iv) impart new dynamism to Monitoring Boards to make them genuine project monitoring instruments; and (v) produce periodic reports on project management.

The measures plamed for monitoring and eveluation will terget: (i) improved training for the staff of project monitoring units atd planning/monitoring structures and upgrading their material resources; (ii) gradual creation of monitoring and evaluation structures in the ministries which lack thern; (iii) pronotion of a framework for regular consultation between the various project structures with a view to harmonizing data gathering methods and instruments and promoting the exchange of information; and (iv) the introduction or strengthening, at the project level as well as in the supervisory administrations, of mechanisms for monitoning project and program impact.

Harmonization of the procedures of donors and ienders will be sought through approaches deemed the most appropriate for achieving greater convergence in the application of procedures, while taking into account the specific requirements of each partner. In this framework, the government will emphasize the budgetary support approach over the project approach.

In the area of strengthening private sector expacities, the government interds to: (i) develop and implement an appropriate training program for strengthening the capacities of national enterprises; (ii) encourage partnership/association between national and foreign enterprises; (iii) examine the possibilities of establishing specialized guarantee and financing institutions; and (iv) introchuce a database on the construction and putlic works sector and defite the techrical standards applicable to that sector.

78. The sound management of public resources is a critical factor in achieving the poverty reduction objectives. It will be sought by: (i) modernizing the tax administrations with a view to increasing their yield and reducing transaction costs for the private sector; (ii) improving the budget allocation process by adopting a global MTEF and unifying the budget; (iii) revising the legal framework for budget execution and the gradual decentralization of payment authorization; (iv) computerization of public expenditure and strengthening the accounting system; and (v) the development of the public expenditure monitoring, control, and evaluation system.

79. Decentralization will continue to receive sustained attention through the strengthening of institutional mechanisms, improved resource mobilization, and building the management capacity of the municipalities. The main activities in 2003 will be: (i) implementation of programs in support of decentralization; (ii) introduction of mechanisms for distributing FRD; and (iii) formalizing the region as a decentralized territorial governing body. Furthermore, the implementation of the PRSP at the regional level will enter an active phase, in keping with the provisions of the guideline law on combating poverty (see Box 8). 
80. As regards to capacity building in civil society, the following activities will be carried out in 2003: (i) finalization and launch of the FAPONG campaign; (ii) introduction of the procedure for authorization of development associations; and (iii) implementation of programs to build capacity of NGOs, labor units, and the media.

81. The establishment of an integrated system for monitoring and evaluation of the PRSP is one of the government's priorities for the next two years. In particular, major efforts will be made to strengthening the poverty monitoring and analysis system so as to enhance its ability to identify the impact of policies and programs on the people's living conditions and to make relevant recommendations so as to enhance the chances of PRSP success. These efforts will focus mainly on: (i) revision of the PRSP indicators; (ii) the regular conduct of targeted surveys (EPCV for 2003/04, Agricultural Survey, Enterprise Survey, etc.); (iii) cartying out qualitative studies and surveys; (iv) strengthening administrative statistics; (v) developing the poverty analysis function through training and modeling; (vi) systematically performing analysis of the social and poverty impact of the reforms; and (vii) adapting the institutional framework to the regionalization requirements of the PRSP. Finally, the system for monitoring and evaluating the PRSP should make it possible to provide the information needed for monitoring achievement of the Millennium Development Goais (see Box 9).

\section{Box 8: The Millennium Development Goals (MDGs)}

On September 8,2000, the leaders of 192 United Nations member countries meeting at the General Assembly adopted the United Nations Millennium Declaration, which constitutes a solemn undertaking by the highest levels of government in favor of poverty reduction and sustainable human development. This declaration led to the development of Millennium Development Goals (MDGs)-globai objectives for 2015, which constitute an ambitious agenda for recucing poverty as well as its causes and manifestations.

The objectives are as follows: Halve extreme poverty and hunger, achieve universal primary education and gender equality, reduce by two-thirds the mortality rate among children under five, and by three-quarters the ratio of women dying in childbirth, reverse the spread of HIV/AIDS and the incidence of malaria, and achieve sustainable development and environmental sustainability. They further include the objective of developing a global partnership for development, with objectives for aid, trade, and debt relief. Each objective is associated with targets (quantified objectives) as well as indicators.

The first follow-up report on MDGs in Mauritania was prepared in January 2003, with assistance from the Agencies of the United Nations Development Group (UNDG). It concluded that satisfactory progress is being made as regards to changes in the incidence of poverty, access to education, safe drinking water, gender equality, and the empowerment of women. However, performance is more modest as regards the objectives for child mortality, maternal health, HIV/ADS, mataria, and the environment.

in order to achieve the MDGs, since February 2003 the government has been implementing a project to support the national ownership of these objectives with a view to actieving impropements in public pol icies. This project is aimed at improving public policy formulation and strengthening the management of the economy by taking the MDGs into account.

\subsection{Risks}

82. Implementation of the PRSP continues to be confronted by risks associated with: (i) the vulnerability of the economy; (ii) the inadequacy of institutional capacities; (iii) weaknesses in public resource management; and (iv) mobilization of the financing for the action plan.

83. Economic growth, and hence poverty reduction, remains vulnerable to_world market price fluctuations owing to the strong concentration of goods exports (almost 100 percent) on two products (iron and fish), and the vagaries of the weather given the sizable weight of the rural sector 
in national output (18.9 percent of GDP for agriculture and livestock in 2001) and in employment (over 50 percent), particularly among the poorest.

84. In respect of institutional capacities, successful PRSP implementation depends in large measure on: (i) improving absorptive capacity and successful efforts to enhance the project management capacities of various stakeholders, in particular those at the grassroots (municipalities, local operators, and NGOs); (ii) the public sector's capacity to improve the business climate and stimulate competition; and (iii) development of the strategic functions of prospective analysis, economic management, budget programming, monitoring, and evaluation, and aid coordination.

85. Regarding public resource management, the major constraints pertain to: (i) the capacity to target the poor; (ii) insufficient delegation of resources to the level of the sectors and ragions that are accountable for results; and (iii) the weakness of the public expenditure monitoring systern.

86. Mobilization of the financing for the priority actions for 2003-04 is essential to achieving the objectives of the strategy and the Millennium. Development Objectives. The delays in mobilizing funding for the additional financing requirements attributable to international economic conditions may retard the implementation of this action plan.

\subsection{External assistance needs}

87. External assistance continues to be a decisive factor in the success of the PRSP at two levels: (i) the mobilization of resources for financing the action plan; and (ii) enhancing national capacities for program design, execution, and monitoring/evaluation.

88. The 2003-04 action plan, covering the last two years of the first PRSP period, is supported by a PIP in the amount of almost UM 119 billion, of which over UM 33 billion must be mobilized in order to permit program execution in 2004. As regards financing the PRSP action plan for the 2003-04 period, the additional requirements identified (see Annex 4) amount to almost US\$150 million.

89. Regarding capacity building, the requirements for external assistance relate for the most part to the following areas:

- Economic management and the development of ex ante analysis instruments for assessing the impact of public policies on household living conditions;

- Preparation of the global MTEF and the MTEFs for the water resources, rural electrification, and fisheries sectors, as well as the finalization of the MTEF for the rural development sector;

- Evaluation of the social and anti-poverty impact of the education and health policies;

- Regionalization of the PRSP, with the development of Regional Poverty Reduction Programs (RPRPs);

- Conduct of the next phase of the ongoing survey of living conditions (EPCV) for the period 2003-04, which should take the new requirements for regionalization of the PRSP into consideration;

- Introduction of an integrated system for PRSP monitoring and evaluation;

- Building private sector capacities so that it can fully serve as the driving force behind growth; and

- Strengthening civil society's capacities for designing, implementing, and monitoring/evaluating targeted programs to combat poverty. 


\section{ANNEXES}




\section{Annex 1: Revised Poverty Reduction Objectives}

\begin{tabular}{|c|c|c|c|c|c|}
\hline \multirow{2}{*}{ Priority abjectives and performan ze indicators } & \multicolumn{2}{|c|}{ Baseline } & \multicolumn{3}{|c|}{ Quantifigd objectives } \\
\hline & Date & Value & 2004 & 2010 & 2015 \\
\hline \\
\hline Number of poor (in thousands) & 2000 & 1,161 & 1,141 & 860 & 706 \\
\hline Ineidence of poverty. & 2000 & $46.3 \%$ & $41.3 \%$ & $27.1 \%$ & $19.7 \%$ \\
\hline Ineidence of extreme poverty & 2000 & $31.4 \%$ & $26.9 \%$ & $13.2 \%$ & $6.6 \%$ \\
\hline Depth of poverty & 2000 & $17 \%$ & $14.3 \%$ & $67 \%$ & $34 \%$ \\
\hline Severity of povaty & 2000 & $8.2 \%$ & $6.6 \%$ & $2.3 \%$ & $10 \%$ \\
\hline Gini index & 2000 & $39 \%$ & $39 \%$ & $36.7 \%$ & $35.6 \%$ \\
\hline \multicolumn{6}{|l|}{ Accelerate economic grownh ${ }^{2}$} \\
\hline Angual rate of GDP grouth & 2000 & 5.2 & 6.1 & $s$ & 3 \\
\hline Annual rate of per capita GDP growth & 2000 & 27 & 3.5 & 25 & 25 \\
\hline Investment ratio, including oil exploration investment (in percent of GDP] & 2000 & 32.1 & 42.6 & 35.6 & 35.8 \\
\hline \multicolumn{6}{|l|}{ Preserve macroeconomic stability } \\
\hline Inflation raie (in percent) & 2000 & 3.3 & 3.7 & 3.5 & 3.5 \\
\hline Budgat balance (in perceat of GDP) & 2000 & -.4 .4 & -2.7 & -3.0 & .3 .0 \\
\hline $\begin{array}{l}\text { Climent extemal bulance, exeluding officiai trathers and oil fin percent of } \\
\text { GDP ) }\end{array}$ & 2000 & .5 .8 & .80 & -10.0 & -9.8 \\
\hline Gross reserves (in months of imports) & 2000 & 6.9 & 6.4 & 6.0 & 6.0 \\
\hline \multicolumn{6}{|l|}{ Improve overall education level } \\
\hline Gross primary enrollinent ratio & 2000 & $88 \%$ & $90 \%$ & $98 \%$ & $100 \%$ \\
\hline OTass enrollinent ratio of girls & 2000 & $85 \%$ & $92 \%$ & $98 \%$ & $100 \%$ \\
\hline Pioportion of chilaren completing basic cycle & 2000 & $55 \%$ & $56 \%$ & $76 \%$ & $100 \%$ \\
\hline Proportion of gitls resching $\mathrm{E}^{\mathrm{h}}$ year of basic cycle & 2000 & $51 \%$ & $58 \%$ & $73 \%$ & $100 \%$ \\
\hline Now cntrants in first year of secondary school & 2000 & 14,814 & 17,991 & 27,816 & 46,514 \\
\hline Student teacher ratio in first cycle of second arr school & 2600 & 32 & 26 & 27 & 27 \\
\hline Adult illiteracy ratio & 2800 & $42.8 \%$ & $23 \%$ & $13 \%$ & $5 \%$ \\
\hline Education expenditure as a percentage of oDP & 2000 & $4.5 \%$ & $6.2 \%$ & $6 \%$ & $6 \%$ \\
\hline \multicolumn{6}{|l|}{ Imprave averall be alth conditions } \\
\hline Life expectancy at birth (years) & 1998 & 53.6 & 56 & 59 & 62 \\
\hline Synthetic fentility index & 2000 & 4.7 & 4.5 & 44 & 4.2 \\
\hline Infantrchild mor ality rate per 1,000 & 2000 & 87 & 80 & 75 & 72 \\
\hline Infant/child mortality rate per 1,000 & 2000 & 135 & 228 & 123 & 122 \\
\hline Froportion of assisted childbirths & 2000 & $56.9 \%$ & $64 \%$ & $71 \%$ & $74 \%$ \\
\hline Frevalene of HIV am & 2000 & 0.5 & $<1$ & $<1$ & $=1$ \\
\hline Heatth service coverage ratio within $5 \mathrm{~km}$ radivs & 2000 & $67 \%$ & $77 \%$ & $90 \%$ & $95 \%$ \\
\hline Malnutrition pate (weight for agel among children under 5 & 2000 & $32 \%$ & $20 \%$ & $15 \%$ & $13 \%$ \\
\hline \multicolumn{6}{|l|}{ Inerease acepss to safe drinking wzter } \\
\hline Proportion of households connected to water system & 1997 & $35 \%$ & $45 \%$ & $54 \%$ & $60 \%$ \\
\hline Frice per eubic meter of water (in U,S. dollan) & 1997 & 1.03 & 1.03 & 1.07 & 1.10 \\
\hline \multicolumn{6}{|l|}{ Increase incomes and improve living conditions in rura } \\
\hline Incidence of nural povety & 2000 & $61.2 \%$ & $54.9 \%$ & $44.0 \%$ & $34,0 \%$ \\
\hline Incidenoc of cxtrtme noral poverty & 2000 & $44.1 \%$ & $36,0 \%$ & $28.8 \%$ & $24.0 \%$ \\
\hline Gini index in rural areas & 2000 & $36.7 \%$ & $34.2 \%$ & $32.2 \%$ & $306 \%$ \\
\hline Agrnal rate of agricultual GoP growh & 2000 & $0.5 \%$ & $5.5 \%$ & $10 \%$ & $10 \%$ \\
\hline Yield of irigated rice (ratric toushalyzar, with of -segsong crop & 2000 & 4.2 & 3.4 & 10 & 12 \\
\hline Rate of ive animal health coverage (required vocines? & 1999 & $60 \%$ & $70 \%$ & $77 \%$ & $85 \%$ \\
\hline Field of dryiand food erope & 2000 & 0.5 & 0.8 & 1.0 & 1.0 \\
\hline \multicolumn{6}{|l|}{$\begin{array}{l}\text { Inere ase incomes and improve living conditions in al-risk nelghborhoods } \\
\text { of major cities and second } a r y \text { cities }\end{array}$} \\
\hline Iarget population (in thousatds) & 2000 & 540 & 266 & 940 & 700 \\
\hline Number with access to microcredit (in thousands) & & & 20 & 40 & 80 \\
\hline Cumulative volume of microcred its (in millions of ouguiyas) & 2000 & 200 & 2,500 & 5,000 & 6000 \\
\hline Number of land tenure deeds regul arized in poor neighborhoods & 2000 & 800 & 16,000 & 30,000 & 40,000 \\
\hline Number of newly ingroved piots & & & 8,000 & 20,000 & 35,000 \\
\hline Access to subsidized housing in eoor neighborhoods (householde) & 2000 & 300 & 10,000 & 20,000 & 35,000 \\
\hline $\begin{array}{l}\text { Per capita consumption of safe drinking water (iters per day) in poor } \\
\text { reightborhoods }\end{array}$ & 1997 & 10 to 20 & 20 to 30 & 40 & 50 \\
\hline Rate of access to safe drinking water in poor neighborhoods & 1997 & $35 \%$ & $40 \%$ & $50 \%$ & $60 \%$ \\
\hline Frice per cubic meter of water cin US dollars) in pour tei shoorhoods & 1997 & 2 to 3 & $<1$ & $<0.5$ & $<0.5$ \\
\hline $\begin{array}{l}\text { Price per cubic meter of water in poor neighborhoods as a multiple of prive in } \\
\text { other ncighborhoods }\end{array}$ & 1997 & 3 & $\mathrm{j}$ & 0.8 & 0.8 \\
\hline Rate of access to sanitalion services in poor neiphborhoods & 2000 & $10 \%$ & $15 \%$ & $26 \%$ & $36 \%$ \\
\hline
\end{tabular}

I The 2002 data are still provisional for GDP, public finarices, and the balance of payments. The estimates for 2002 and the projections will be revised upon completion of the macroconomic framework exercise currently in progress. 


\section{Annex 1 bis: Monitoring Indicators for Short-Term Poverty Reduction}

\begin{tabular}{|c|c|c|c|c|c|c|}
\hline \multirow[t]{2}{*}{ Priority abjectives and performance indicators } & \multicolumn{2}{|c|}{ Baseline } & \multirow[b]{2}{*}{2001} & \multirow[b]{2}{*}{2002} & \multicolumn{2}{|c|}{$\begin{array}{l}\text { Quantified } \\
\text { objectives }\end{array}$} \\
\hline & Date & Value & & & 2003 & 2004 \\
\hline \multicolumn{7}{|l|}{ Accelerate economic growth } \\
\hline Annual rate of GDP growth & 2000 & 5.2 & 4.0 & 3.3 & 5.4 & 6.1 \\
\hline Arnual rate of per capita GDP growth & 2000 & 2.7 & 1.6 & 0.9 & 2.9 & 3.6 \\
\hline Investment tatio, including in the oil sector (in percent of GDP) & 2000 & 32.1 & 34.5 & 33.0 & 43.1 & 42.6 \\
\hline \multicolumn{7}{|l|}{ Preserve macroeconomic stability } \\
\hline Inflation rate, period average (in percent) & 2000 & 3.3 & 4.7 & 4.0 & 6.4 & 3.7 \\
\hline Budget balance (in percent of GDP) & 2000 & -4.4 & -5.5 & 6.2 & -2.1 & -2.7 \\
\hline $\begin{array}{l}\text { Current external balance, including il related payments and } \\
\text { exeluding official transfers (in percent of GDP) }\end{array}$ & 2000 & -9.3 & -18.3 & -11.7 & -22.1 & -27.6 \\
\hline Gross reserves (in months of imports) & 2000 & 6.9 & 6.8 & 8.7 & 7.2 & 6.4 \\
\hline \multicolumn{7}{|l|}{ Improve overall education level } \\
\hline Rate of access to basic education & 2000 & 93 & 97 & 111 & 111 & 111 \\
\hline Retention ratio & 2000 & 55 & 51 & 48 & 52 & 56 \\
\hline Gross enrollment ratio & 2000 & 88 & 87 & 88 & 88 & 90 \\
\hline Rate of access to first cycle of secondary school ${ }^{3}$ & 2000 & 25 & 28 & 26 & 26 & 28 \\
\hline Education expenditure as a percentage of GDP & 2000 & 4.5 & 4.6 & 5.9 & 5.9 & 62 \\
\hline \multicolumn{7}{|l|}{ Improve overall health conditions } \\
\hline Proportion of assisted childbirths & 2000 & 56.9 & & 60 & 62 & 6 \\
\hline Rate of DTC3 vaccination & $2000^{-1}$ & 39.9 & 52 & 70 & 75 & 75 \\
\hline Prevalefice of HIV among pregnant women & 2000 & 0.5 & 0.5 & $<1$ & $<1$ & $<1$ \\
\hline Health expenditure burden, first quintile & 2000 & 0.3 & 0.3 & $<0.3$ & $<0.3$ & $<0.3$ \\
\hline Education expenditure as a percentage of GDP & 2000 & 1.6 & 2.0 & 3.4 & 3.4 & 3.5 \\
\hline \multicolumn{7}{|l|}{$\begin{array}{l}\text { Increase incomes and improve living conditions in rural } \\
\text { areas }\end{array}$} \\
\hline Growth Rate of agricultural GDF & 2000 & -7.6 & -13.4 & -10.0 & 14 & 5 \\
\hline $\begin{array}{l}\text { Yield of irrigated rice (metric tons/ha/year, with off-season } \\
\text { crop }\end{array}$ & 2000 & 4.2 & 4.5 & 4.8 & 5.1 & 5.4 \\
\hline Yield of dry land food crops & 2000 & 0.5 & 0.6 & 0.6 & 0.7 & 0.8 \\
\hline \multicolumn{7}{|l|}{$\begin{array}{l}\text { Increase incomes and improve living conditions in at-risk } \\
\text { neighborhoods of major cities and secondary cities }\end{array}$} \\
\hline Cumulative volume of microetedits (in millions of ouguiyas) & 2000 & 200 & & & & 2,500 \\
\hline $\begin{array}{l}\text { Number of land tenute deeds regularized in poor } \\
\text { neighborhoods }\end{array}$ & 2000 & 800 & & & & 16,000 \\
\hline \multicolumn{7}{|l|}{ Number of newly improved plots } \\
\hline $\begin{array}{l}\text { Access to subsidized housing in poor neighborhoods } \\
\text { (households) }\end{array}$ & 2000 & 300 & & & & 10,000 \\
\hline
\end{tabular}

${ }^{2}$ Nurnber of new entrants/corresponding age cohort. 
Annex 1 ter: Comparison of PRSP Objectives and Millennium Development Goals (MDGs)
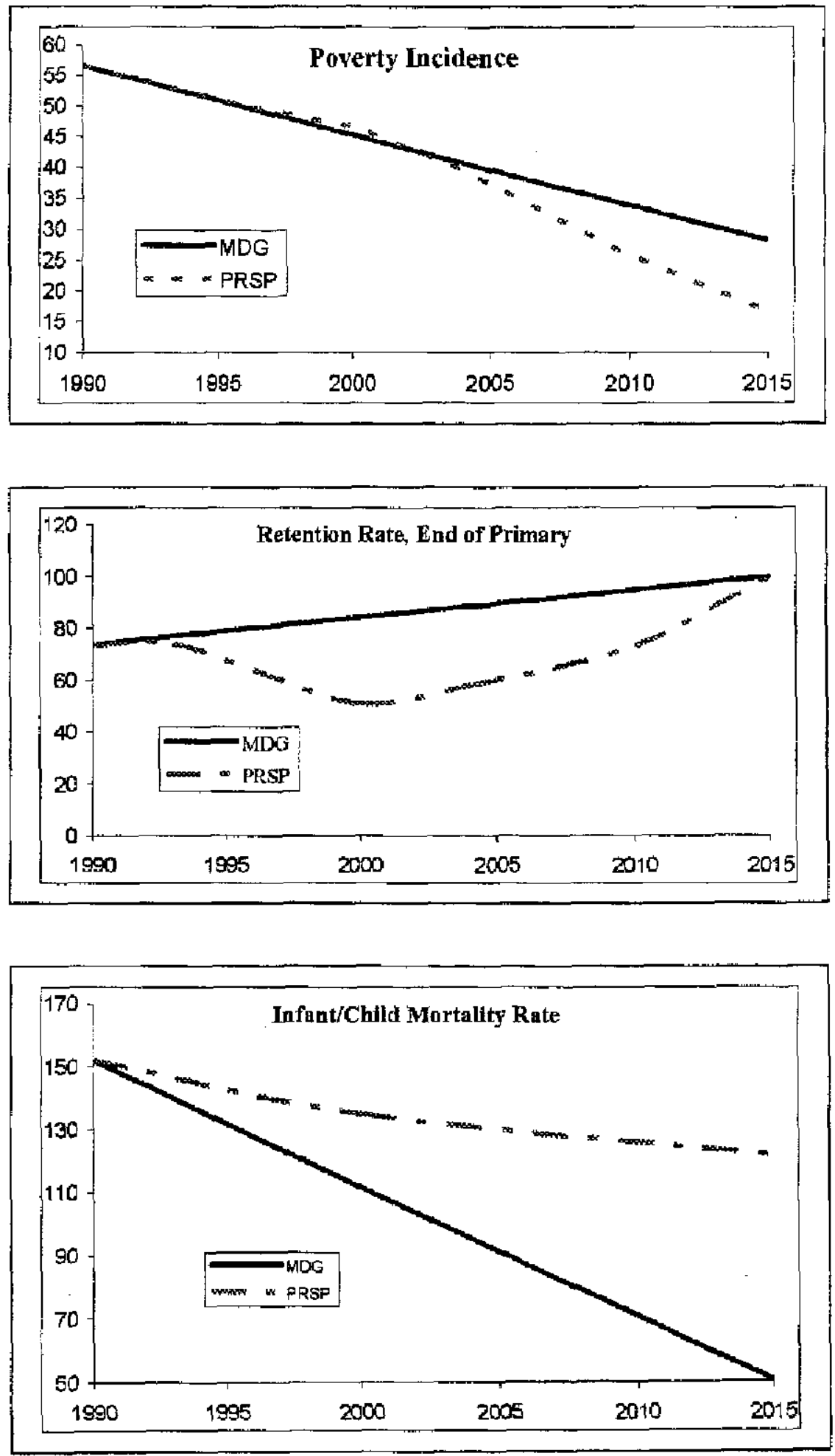

CInternational Monetary Fund. Not for Redistribution 


\section{Annex 2: Matrix of Priority Measures of the PRSP}

\begin{tabular}{|c|c|c|c|c|}
\hline Olyectives for $2001-14$ & Priority actions carried out in 2001 & Rriorty actions plained for 2002 & Priority actors carried out in 2002 & Priority actions plammed for 2003 \\
\hline \multicolumn{5}{|c|}{ FOCUS 1: ACCELERATED AND REDISTRIBUTIVE GROWTH } \\
\hline $\begin{array}{l}\text { Growth } \\
\text { Accelerate growth and reach a trend } \\
\text { rate of } 7 \text { percent: } \\
\text { Implementation of macro policies, } \\
\text { extemal sector policies, etc. }\end{array}$ & $\begin{array}{l}\text { - See macro policies, external sector policies, } \\
\text { etc. }\end{array}$ & $\begin{array}{l}\text { - See macro policies, external sector } \\
\text { policies, etc. }\end{array}$ & $\begin{array}{l}\text { - } \begin{array}{l}\text { See macro policies, external sector } \\
\text { policies, etc. }\end{array} \\
\end{array}$ & $\begin{array}{l}\text { - See macro golicies, external sector } \\
\text { policies, etc. }\end{array}$ \\
\hline $\begin{array}{l}\text { Macroecoitomic framework } \\
\text { - Maintain an inflation rate below } \\
\quad 3 \text { percent and a consolidated } \\
\text { government deficit below } 3 \text { percent: } \\
\text { Maintain revenue and expenditure } \\
\text { levels consistent with PRSP } \\
\text { objectives and corresponding to } 25.7 \\
\text { percent and } 27.8 \text { percent of GDP on } \\
\text { average } \\
\text { letroduction of domestic taxation } \\
\text { reform }\end{array}$ & $\begin{array}{l}\text { - Reduce Blc from } 40 \text { percent to } 35 \text { percent } \\
\text { and increase dedtuctibility of the IMF from } \\
50 \text { percent to } 75 \text { percent } \\
\text { - Creation of the Large Enterpige } \\
\text { Directorate and strengthening of tax } \\
\text { collection teams }\end{array}$ & $\begin{array}{l}\text { - Direct taxation reduction and } \\
\text { simplification in the context of the } \\
2002 \text { Budget law } \\
\text { - Strengthening of tax collection teams } \\
\text { (additional budget allocations, } \\
\text { creation of an adwances system, } \\
\text { incentive bonuses for staff) }\end{array}$ & $\begin{array}{l}\text { - Reduce BIC from } 35 \text { percent to } \\
25 \text { percent and full deductibility or the } \\
\text { IMF } \\
\text { Elimination of the proportional } \\
\text { business license tax and simplification } \\
\text { of the flat-rate levy of this tax } \\
\text { Inerease in taxable base of the LRF and } \\
\text { reduction in its rate, with elimination of } \\
\text { deduction } \\
\text { Strengthening of tax collection teams } \\
\text { (additional budget allocations, } \\
\text { introduction of IT application software, } \\
\text { provision of computer equipment, } \\
\text { veluicles, personnet incentives, ete.) }\end{array}$ & $\begin{array}{l}\text { Annual objective } 2003 \\
\text { - } \\
\text { Direct taxation reduction and } \\
\text { simplification in the context of the } \\
2003 \text { Budget Law }\end{array}$ \\
\hline $\begin{array}{l}\text { Maintain current account deficit } \\
\text { (excluding official transfers) below } \\
\text { I5.5 percent of GDP and external } \\
\text { reserves of } 6 \text { months' imports: } \\
\text { Pursuit of a monetary policy based on } \\
\text { market forces, through the use of } \\
\text { indirect liquidity management } \\
\text { instruments and the development of } \\
\text { the Treasury bill market } \\
\text { Implementation of development } \\
\text { policies and prograns for export } \\
\text { sectors (SNM, agricultural } \\
\text { diversification, tourism) } \\
\text { Reduce gaps between borrowing and } \\
\text { lending rates: }\end{array}$ & $\begin{array}{l}\text { - Creation of the special facility, gradual } \\
\text { transfer of government deposits from banks } \\
\text { to the BCM } \\
\text { See export sectors }\end{array}$ & $\begin{array}{l}\text { Creation of the special facility, } \\
\text { gradual transfer of government } \\
\text { deposits from banks to the BCM }\end{array}$ & $\begin{array}{l}\text { - CPMC review of the issue of } \\
\text { transfening public deposits from banks } \\
\text { to the BCM } \\
\text { - See improvement in the economy's } \\
\text { competitiveness and its integration into } \\
\text { world trade, below }\end{array}$ & $\begin{array}{l}\text { - Intiation of the gradual transfer of } \\
\text { goveznment deposits from banks to } \\
\text { the BCM } \\
\text { Sec export sectors }\end{array}$ \\
\hline $\begin{array}{l}\text { Maintain real effective exchange rate } \\
\text { at a level consistent with the current } \\
\text { account objective }\end{array}$ & - Anmual objective 200I & - Annual objective 2002 & - Arnual objective 2002 & - Annual objective 2003 \\
\hline
\end{tabular}

CInternational Monetary Fund. Not for Redistribution 


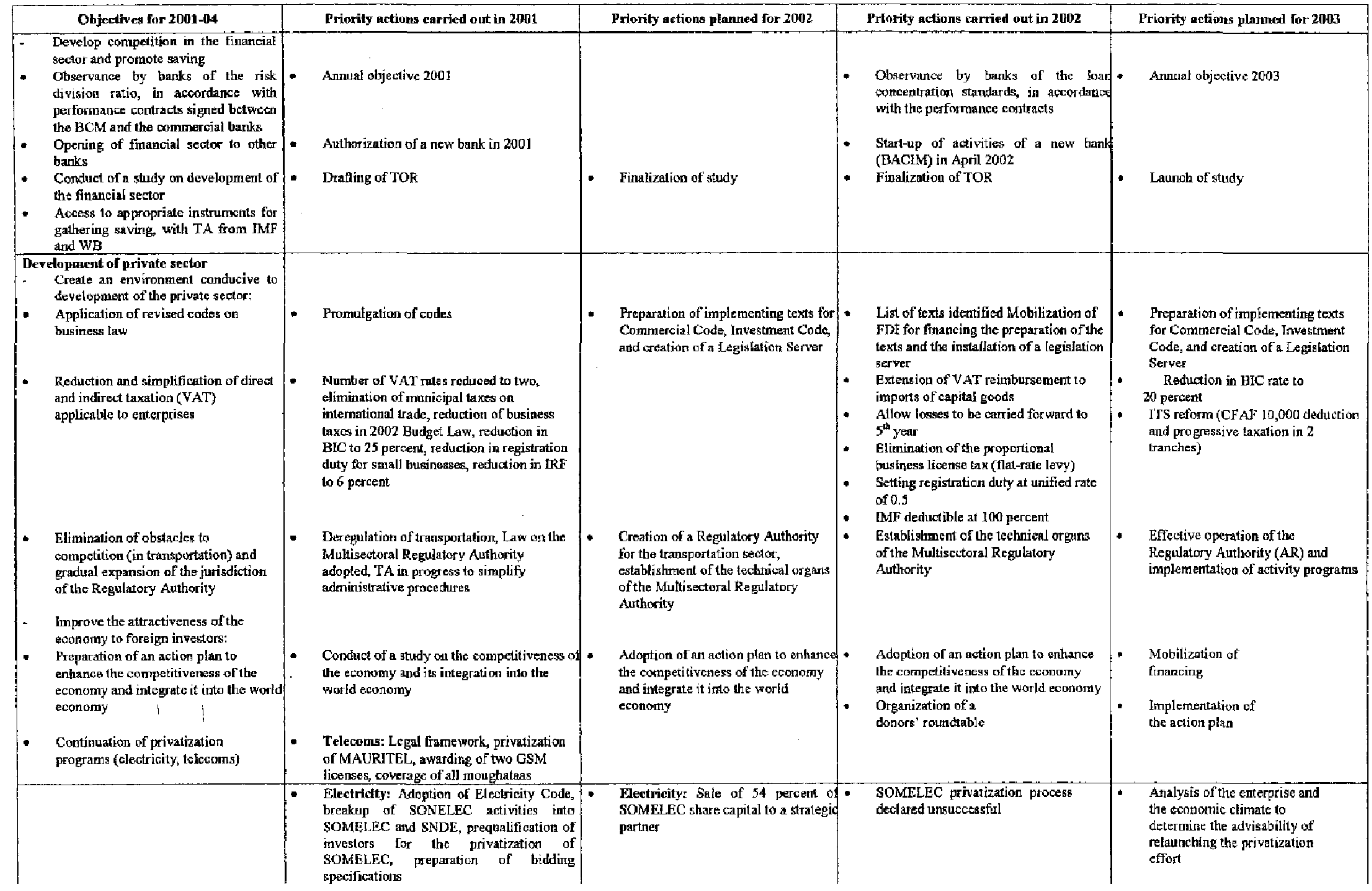

CInternational Monetary Fund. Not for Redistribution 


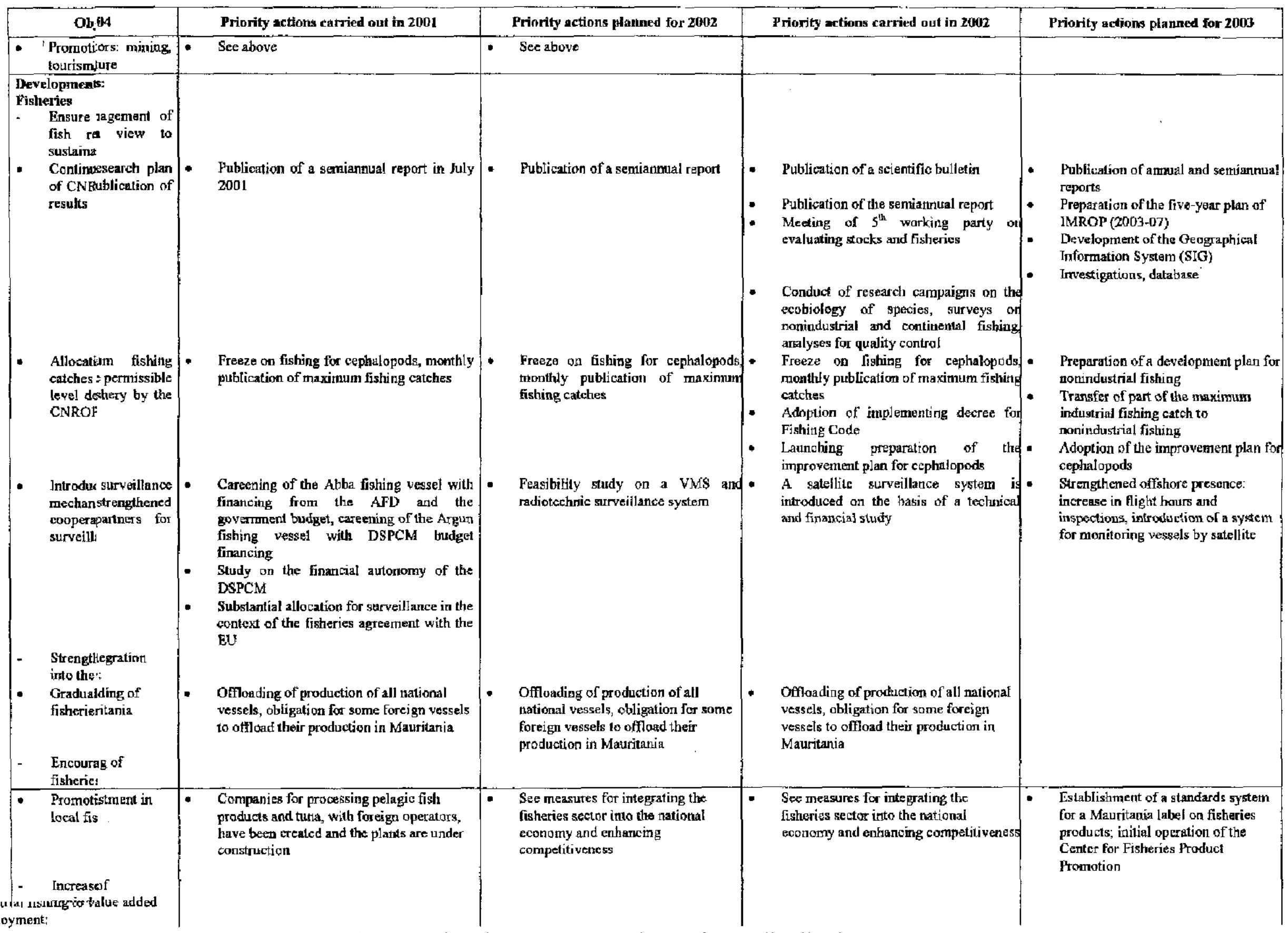

CInternational Monetary Fund. Not for Redistribution 


\begin{tabular}{|c|c|c|c|c|}
\hline Ob.64 & Priority actions carried out in 2001 & Priority actions planned for $\mathbf{2 0 0 2}$ & Priority actions carried out in 2002 & Priority actions planned for 2003 \\
\hline $\begin{array}{l}\text {, Implemructure } \\
\text { progrsin port, fishing } \\
\text { port, litt) and } \\
\text { promotioarticipation } \\
\text { in their }\end{array}$ & $\begin{array}{l}\text { Expansion of the nonindustrial fishing port } \\
\text { of Nouadhibou (NDB), mobilization of } \\
\text { financing, for a littoral development pole } \\
\text { opposite Tiguent, mobilization of financing } \\
\text { for a littoral de velopment pole opposite } \\
\text { PK } 144 \text { (National Highway 1) }\end{array}$ & $\begin{array}{l}\text { Seek frnatcing for a pelagic Elshing } \\
\text { part at NDB, completion of the study } \\
\text { on developing a nonindustrial fishing } \\
\text { port in Tanit, implcmestalion of a } \\
\text { littoral development pole opposite } \\
\text { PK.144 (National Highway 1) }\end{array}$ & 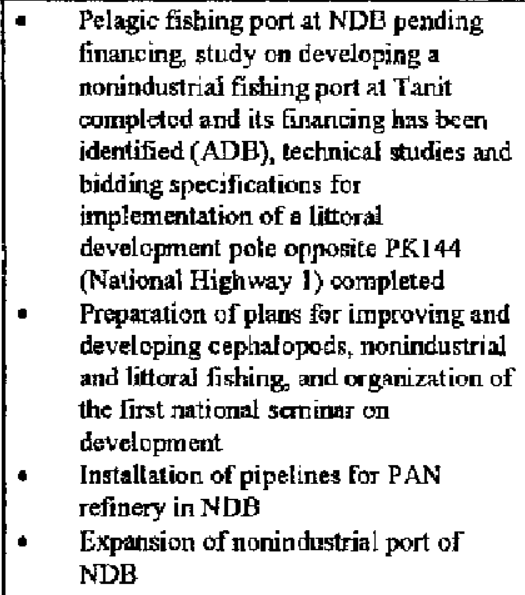 & $\begin{array}{l}\text { Preparation of plans for improving } \\
\text { and developing ceptaxlopods, } \\
\text { nonindustrial and littoral fishing, and } \\
\text { completion of the study on the } \\
\text { artificial reer }\end{array}$ \\
\hline $\begin{array}{l}\text { Mining } \\
-\quad \text { Promot C the mining } \\
\text { sector andribution to } \\
\text { the ecor }\end{array}$ & & & 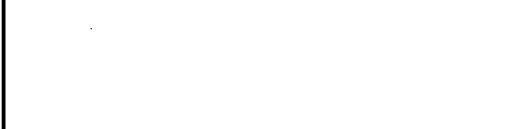 & \\
\hline $\begin{array}{l}\text { - DissemiCode and } \\
\text { continunigns for } \\
\text { foreign }\end{array}$ & $\begin{array}{l}\text { - Dissemination of the Mining Code, } \\
\text { initiation of cartographic work in northern } \\
\text { and central zones, presentation of } \\
\text { geophysical Findings on northern zone }\end{array}$ & $\begin{array}{l}\text { Dissemination of the Mining Code, } \\
\text { cartographic work central zone, } \\
\text { establishment of a data room, and } \\
\text { presentation of cartographic findings }\end{array}$ & $\begin{array}{l}\text { - Promulgation of the law } \\
\text { establishing a standard mining } \\
\text { agreement } \\
\text { - Decree setting mining laxes and } \\
\text { royalties } \\
\text { Establishment of a data room, and } \\
\text { presentation of cartographic } \\
\text { findings, geological mapping of } \\
\text { entire national territory at } \\
1: 500,000, \text { prodtction of } 33 \text { maps } \\
\text { at } 1: 200,000, \text { establishment of an } \\
\text { SIGM and of SIGE } \\
\text { Decree implementing the mining } \\
\text { law on the environment and } \\
\text { quarries }\end{array}$ & $\begin{array}{l}\text { - Continued efforts to promote } \\
\text { the mining sector, in particular } \\
\text { as regards oil, diamonds, gold, } \\
\text { copper, and phosphates } \\
\text { Finalization of regulatory texts } \\
\text { - Mapping of entire national } \\
\text { territory at } 1: 500,010,26 \\
\text { geological at } 1: 200,000 \text { of } \\
\text { areas with high nining } \\
\text { potential } \\
\text { - Airborne geological survey of } \\
\text { extreme south }\end{array}$ \\
\hline $\begin{array}{l}\text { - Continutexploration } \\
\text { prograrr }\end{array}$ & - Exploration program 2001 & - Exploration program 2002 & $\begin{array}{l}\text { Several new exploration permits } \\
\text { have been pranted } \\
\text { (gold, diamonds, efc.) and } \\
\text { encouraging indicators have been } \\
\text { found }\end{array}$ & $\begin{array}{l}\text { Exploration program 2003: } \\
\text { Drilling of additional oil wells } \\
\text { and mining probes }\end{array}$ \\
\hline - ImplemiM & $\begin{array}{l}\text { - Preparation of bidding specifications for } \\
\text { implementation of the Spirale project }\end{array}$ & - Emplemerstation of the Spirale project & $\begin{array}{l}\text { Discovery of oil and ges fields (4 } \\
\text { offshore wells) and continued } \\
\text { exploration in this area } \\
\text { Continuation of program to renew } \\
\text { the equiptipment of SNIM and } \\
\text { enhance productivity }\end{array}$ & $\begin{array}{l}\text { - Completion of work in May } \\
2003\end{array}$ \\
\hline $\begin{array}{l}\text { Tourism } \\
\quad \begin{array}{l}\text { Build outism } \\
\text { potentia }\end{array}\end{array}$ & & & & \\
\hline
\end{tabular}




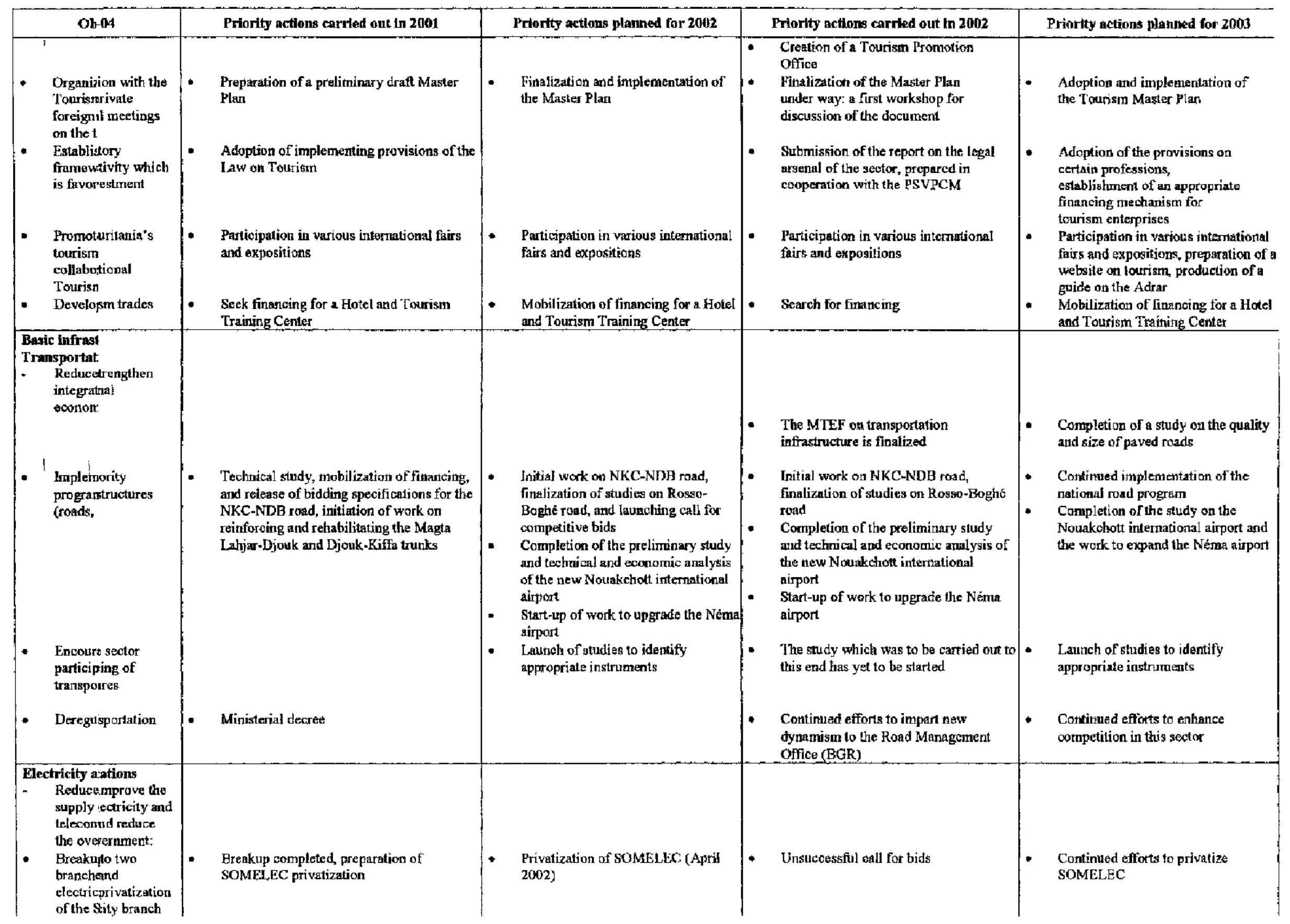

CInternational Monetary Fund. Not for Redistribution 


\begin{tabular}{|c|c|c|c|c|}
\hline Ob-04 & Privrity actions carried ont in 2001 & Priority actions planned for $\mathbf{2 0 0 2}$ & Priority actions carried out in 2002 & Priority actions plasuned for 2003 \\
\hline $\begin{array}{l}\text { - Pronotfication and } \\
\text { control } \\
\text { * Enhancroleum } \\
\text { product } \\
\text { - Privatiat of } \\
\text { MAUR } \\
\text { Contintni programs, } \\
\text { in celluirticular }\end{array}$ & $\begin{array}{l}\text { Startup of expansion of Nouakchott power } \\
\text { plant, initial work on Manantali- } \\
\text { Nouakchott power line } \\
\text { - Study of Investment Plan for Rural } \\
\text { Electrification, study of controlling energy } \\
\text { savings in pubjic baitdings } \\
\text { Initiation of Security Project for Petroleurn } \\
\text { Products } \\
\text { - Privatizalion complettod } \\
\text { - Connection of five new cities: Zouerate, } \\
\text { Kiffa, Rosso, Atar, and Guerou }\end{array}$ & $\begin{array}{l}\text { - Complefion of expansion of } \\
\text { Nouakchott power plant, jnitial } \\
\text { completion of Manantali-Nouakchot } \\
\text { power line } \\
\text { Study of a wind generating park at } \\
\text { Nouadhibon } \\
\text { Construction of a berth in a protected } \\
\text { ares, a storage area, and transfer pipes } \\
\text { - Operators' annual investment } \\
\text { program } \\
\text { - } \\
\text { Continued implementation of the law } \\
\text { on the telecom sector } \\
\text { Expanding the jurisdiction of the } \\
\text { Regulatory Authority to the water } \\
\text { sector }\end{array}$ & 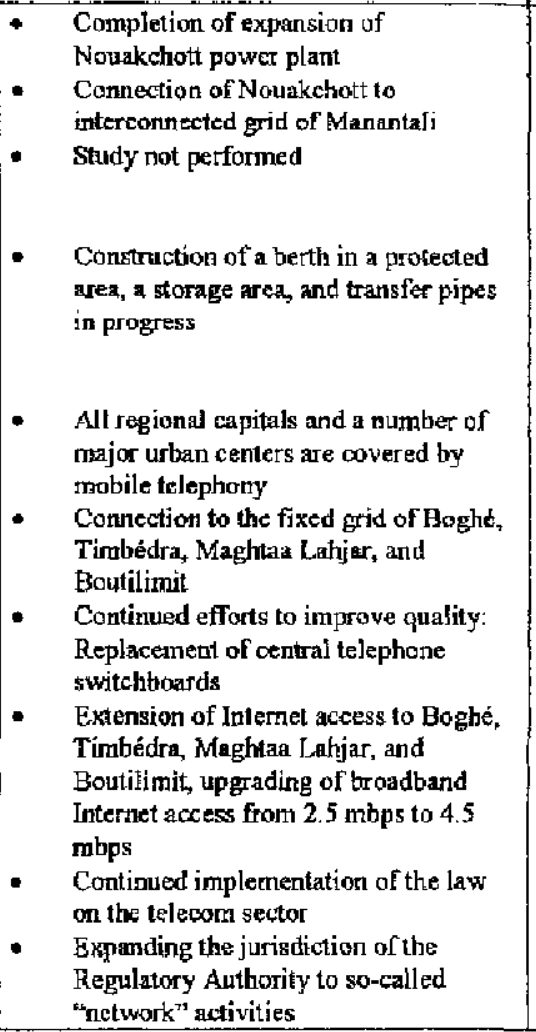 & $\begin{array}{l}\text { Opcrators' nnnual investmont } \\
\text { program, including extension of the } \\
\text { landline teleplione grid } \\
\text { Connection of Maghama, M'bout, } \\
\text { Mederdra, Rkiz, Nouakchott-Kaédi } \\
\text { axis } \\
\text { Connection of } 5 \text { new moughataas by } \\
\text { MAURTTLL and of Aouin, Néma, } \\
\text { and Boghis by Matted } \\
\text { Replacement of central switchboards } \\
\text { in remaining sectoral capitals }\end{array}$ \\
\hline $\begin{array}{l}\text { Rural deqek } \\
\text { - Increasuce poverty } \\
\text { in nural } \\
\text { - Implemority } \\
\text { investitrogtan for } \\
\text { the sect }\end{array}$ & $\begin{array}{l}\text { - Study on updating the rural sector strated } \\
\text { and on iavestment opportunities in the } \\
\text { agricultural and agrofoodstuff, sector }\end{array}$ & $\begin{array}{l}\text { - Organizational and functional study } \\
\text { of the MDRE structures and } \\
\text { instilutional strengthening }\end{array}$ & - Dratt of study available & \\
\hline Livestock & $\begin{array}{l}\text { - Preparation of a PIP for the rural sector } \\
\text { 2002-04 } \\
\text { - Implementation of antrual programs of the } \\
\text { PDIAIM and other subsectoral programs }\end{array}$ & $\begin{array}{l}\text { Study of the impact of tariff teform in } \\
\text { the context of deregulating the rice } \\
\text { market } \\
\text { Implementation of atnual prograns } \\
\text { of the POIAIM, the PGRNP, the } \\
\text { PARP, the Oasis Project, the } \\
\text { PGDRNM (French cooperation), and } \\
\text { the PGRPDE (ADB-OPEC) }\end{array}$ & $\begin{array}{l}\text { - Study of the impact of tariff reform in } \\
\text { the context of dersgulating the rice } \\
\text { market } \\
\text { MTEF being prepared } \\
\text { - Implementation of annual programs of } \\
\text { the PDIANM, the PGRNP, the PARP, the } \\
\text { Gasis Project, the PGDRNM (French } \\
\text { cooperation), and the PGR IPDE (ADB- } \\
\text { OPEC) }\end{array}$ & $\begin{array}{l}\text { Implementation of annLal programs } \\
\text { of the PDIAIM, the PGRNP, the } \\
\text { PARP, the Oasis Project, the } \\
\text { PGIJNM (French cooperation), and } \\
\text { the PGRPDE (ADB-OPEC) }\end{array}$ \\
\hline
\end{tabular}

CInternational Monetary Fund. Not for Redistribution 


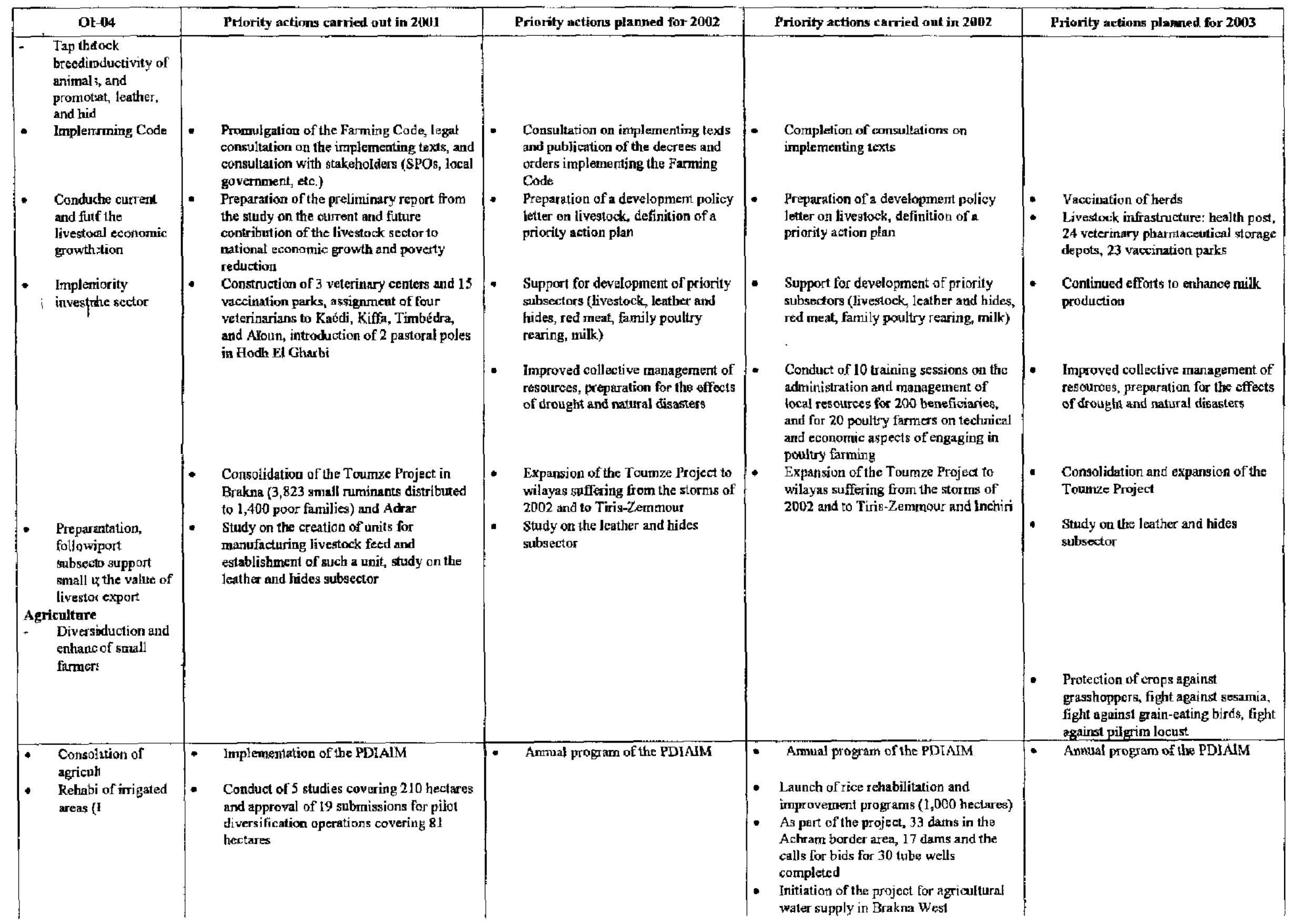

CInternational Monetary Fund. Not for Redistribution 


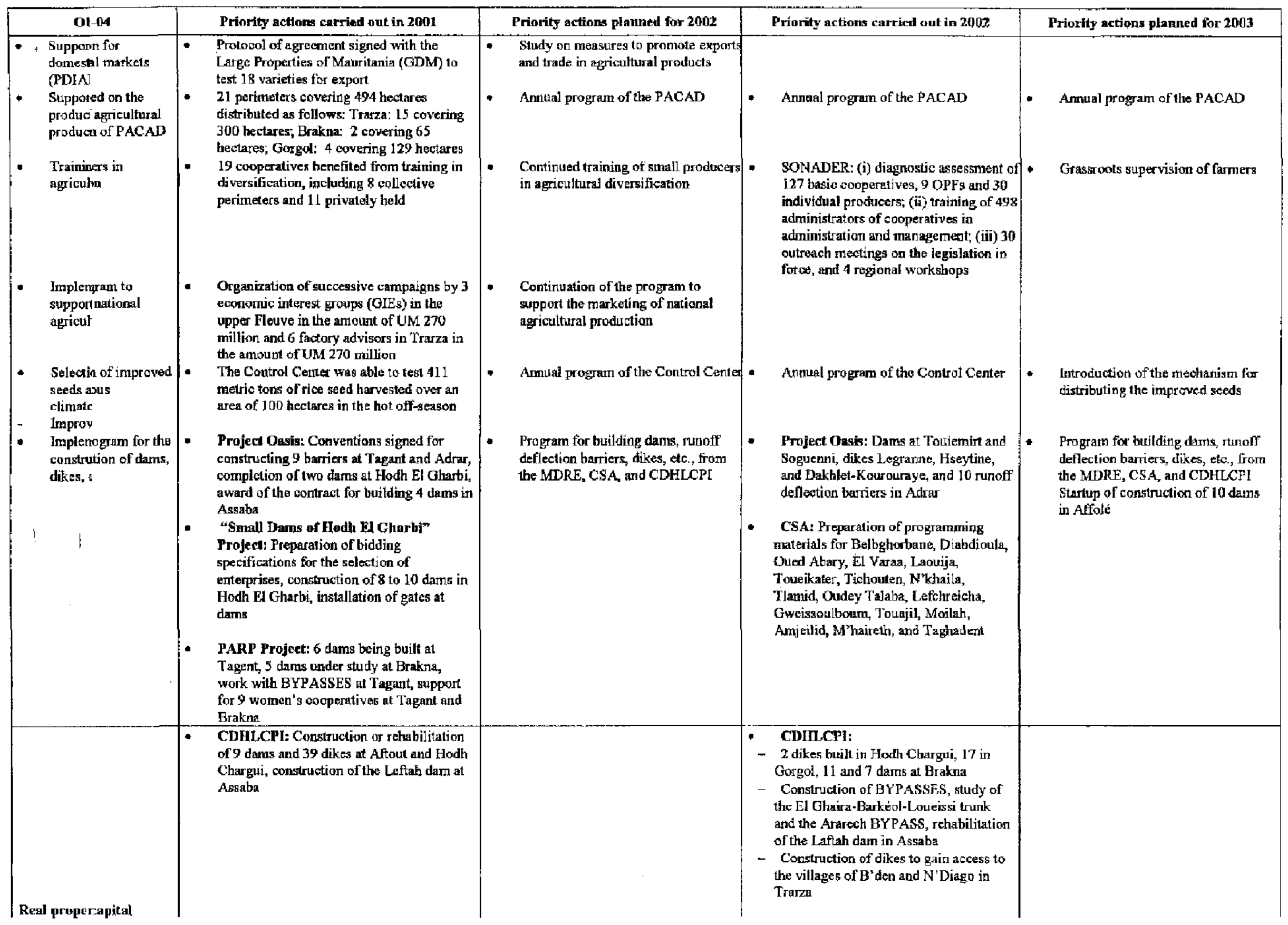

CInternational Monetary Fund. Not for Redistribution 


\begin{tabular}{|c|c|c|c|c|}
\hline * Oh-04 & Priorty actions carried out in 2001 & Priorty actions planned for 2062 & Priority actions carried ont in 2002 & Priorty actlons planned for 2003 \\
\hline $\begin{array}{l}\text { - Inprovs to real and } \\
\text { financit } \\
\text { Tramspal and } \\
\text { implemplementing } \\
\text { decree } 1 \text { Property } \\
\text { and Goind exteasion } \\
\text { of the fs } \\
\text { Consolion of the } \\
\text { agriculik } \\
\text { (UNCA } \\
\text { Suppory of savings } \\
\text { and loarural areas } \\
\text { Training, re services } \\
\text { Promoter, applied } \\
\text { researcitraining } \\
\text { Implemtional } \\
\text { Agriculn }\end{array}$ & $\begin{array}{l}\text { - Dissemination and publication of Decree } \\
2000 / 89 \text { of July } 17,2000 \text {, development of a } \\
\text { program for regularizing } 500 \text { cases } \\
\text { - Consolidation of agricultural credit, in } \\
\text { particular through crop credit. An amount } \\
\text { exceeding UM } 400 \text { million was freed up for } \\
\text { improving an anticipated surface area of } \\
7,857 \text { hectares } \\
\text { Identification of a support program in the } \\
\text { context of the microfinance strategy } \\
\text { currently being prepared } \\
\\
\text { Introduction of pilot outreach offorts } \\
\text { regarding the introduction of forage and } \\
\text { oil-bearing crops, signature of a sunflower } \\
\text { marketing agreemert with the AAADD }\end{array}$ & 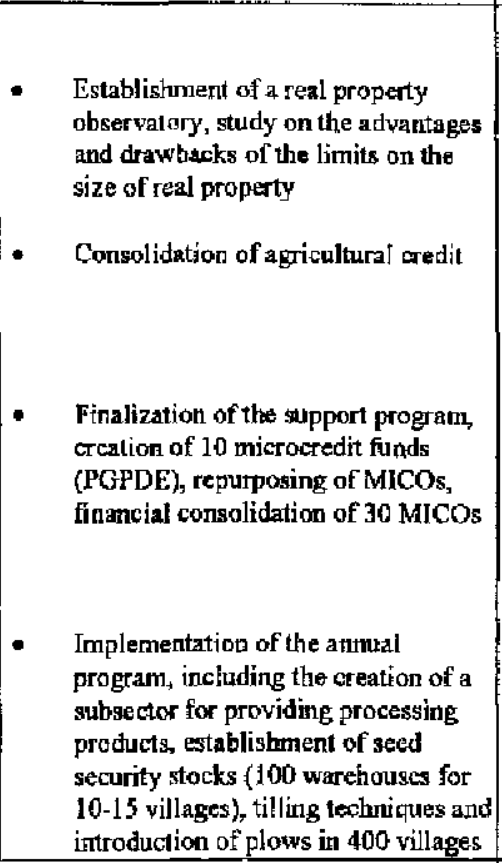 & $\begin{array}{l}\text { - TOR drafted and forwarded for } \\
\text { objections if any } \\
\text { - Consolidation of agricultural credit } \\
\text { - Finalizalion of the support program, } \\
\text { creation of } 10 \text { microcredit funds } \\
\text { (POPDE), repupposing of MICOs, } \\
\text { innancial consolidation of } 30 \mathrm{MICO} \\
\\
\text { Creation of a subsector for providing } \\
\text { processing produots, establishrnent of } \\
\text { seed security stocks, holding of } 3 \\
\text { workshops to promote certified seed in } \\
\text { the major production areas of the valley, } \\
\text { tilling techniques and introduction of } \\
\text { plows in } 400 \text { villages }\end{array}$ & $\begin{array}{l}\text { - Establishment of a real property } \\
\text { observatory, study on the advaniages } \\
\text { and drawbacks of the limits on the } \\
\text { size of real property }\end{array}$ \\
\hline $\begin{array}{l}\text { Rural infras } \\
\text { Increasty, and } \\
\text { accessiastructures in } \\
\text { rural ar }\end{array}$ & & $\begin{array}{l}\text { - Developtnent of a [ong-torm rura] } \\
\text { infrastructure development strategy }\end{array}$ & $\begin{array}{l}\text { - Development of a iontE-term rural } \\
\text { infrastructure development strategy }\end{array}$ & $\begin{array}{l}\text { implementation of the long-term rural } \\
\text { infrastructure development strategy }\end{array}$ \\
\hline $\begin{array}{l}\text { Implemal } \\
\text { infrastronstruction } \\
\text { of ruraliorks to open } \\
\text { access } 1\end{array}$ & $\begin{array}{l}\text { Opening access and providing } \\
\text { infrastricture in the context of CDHLCPI } \\
\text { progratns: opening up Barké ol by building } \\
\text { passages, opening up Bden and N'Diago } \\
\text { (Trarza) }\end{array}$ & $\begin{array}{l}\text { Program for opening access and } \\
\text { providing infrastructures identified in } \\
\text { the context of CDHLCPI programs } \\
\text { and the Oasis Access Project (EU), } \\
\text { study of the Kaédi-MTout trunk, } \\
\text { study and access work for the } \\
\text { production zones between Gani and } \\
\text { Dar El Barka, study on pass } \\
\text { improvement for Oued Kefchi } \\
\text { (PARP) }\end{array}$ & $\begin{array}{l}\text { Program for opening access and } \\
\text { providing infrastructures identified in } \\
\text { the context of CDHLCPI prograuts and } \\
\text { the Oasis Access. Project (ELS), study of } \\
\text { the Kaédi-W'Bout trunk, stady and } \\
\text { access work for the production zones } \\
\text { between Gani and Dar El Barka, study } \\
\text { on pass improvement for Oued Ketchi } \\
\text { (PARP) }\end{array}$ & $\begin{array}{l}\text { Construction of } 42 \text { dams ( } 28 \text { dams in } \\
\text { Yoodh EJ Gharbi, Assaba, Tagant, } \\
\text { Brakna, Gorgol and Adrar to be built } \\
\text { by the MDRE); rehabilitation and } \\
\text { strengthening of } 30 \text { dikes and small } \\
\text { dikes by the CDHCLPI and the CSA } \\
\text { Program on the reaming of water } \\
\text { supply axes in Trarza } \\
\text { Implementation of the infrastructure } \\
\text { program for crop area protection in } \\
\text { eight agnicultural wilayas }\end{array}$ \\
\hline $\begin{array}{l}\text { Targeted prit povt } \\
\text { rural areas: }\end{array}$ & & & & \\
\hline
\end{tabular}

CInternational Monetary Fund. Not for Redistribution 


\begin{tabular}{|c|c|c|c|c|}
\hline OI-04 & Priority acttons carried out in 2001 & Prlortty actions planned for 2002 & Priority actions carried out in 2002 & Priority actlons planued for 2003 \\
\hline $\begin{array}{l}\text { Promol aseas of } \\
\text { extrem grassroots } \\
\text { commovernments } \\
\text { in the pplementation } \\
\text { of grasut progerns: } \\
\text { Purguibcal poverty } \\
\text { reductilving local } \\
\text { govers }\end{array}$ & $\begin{array}{l}\text { Development of basic infrastruct ures in poor } \\
\text { areas, training of groups of cooperatives, } \\
\text { construction and outfitting of multipuxpose } \\
\text { banks and village-level shops, provision of } \\
\text { draft animal plows, carts and barbwire for } \\
\text { small farmers }\end{array}$ & $\begin{array}{l}\text { Pursuit of regional and local poverty } \\
\text { reduction prograns invol ving local } \\
\text { governments and NGOs } \\
\text { - Implernentation of an integFated } \\
\text { poverty reduction program in Aftout } \\
\text { Sud and Karakoro (PASK) }\end{array}$ & $\begin{array}{l}\text { Pursuit of regional and local poverty } \\
\text { reduction programs invol ving local } \\
\text { governments and NGOs } \\
\text { in startup phase: recruitment of } \\
\text { personnel, drafting of procedures } \\
\text { mantuals, etc. }\end{array}$ & $\begin{array}{l}\text { - Pursuit of regional and local poverty } \\
\text { reduction progratns involving local } \\
\text { goveroments and NGOs } \\
\text { - Effective startup of the PASK }\end{array}$ \\
\hline $\begin{array}{l}\text { Food secari } \\
\text { Improv of essential } \\
\text { foodsh } \\
\text { transpent and } \\
\text { attenuabod crises } \\
\text { - Introdinagernent } \\
\text { procedial Security } \\
\text { Stock }\end{array}$ & 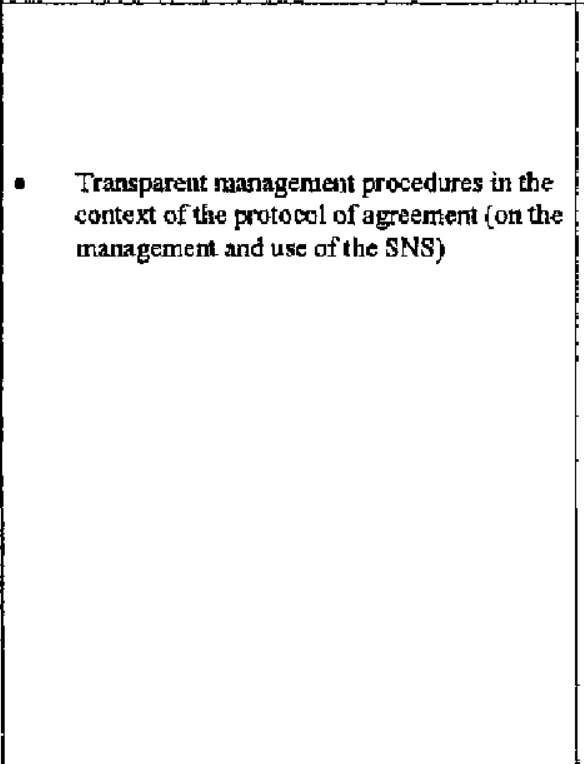 & $\begin{array}{l}\text { Arnual program of the CSA } \\
\text { (microprojects, OSA activities, elc.), in } \\
\text { particular on the basis of EU financing }\end{array}$ & $\begin{array}{l}\text { Preparatory work for evalusating the financial } \\
\text { volume of the national coumterpart } \\
\text { - Work, to bring storage infrastructures } \\
\text { up to standurds: rebabilitation of } 7 \\
\text { warehouses bolding 1,000 matric tons } \\
\text { each } \\
\text { Preparation of managetnent procedures and } \\
\text { documentation and impiementation of the } \\
\text { organization chart, as well as staff training } \\
\text { for the Technical Unit of the National } \\
\text { Security Stock (SNS) } \\
\text { Signing of a Protocol of agreement on } \\
\text { the establishment, management, and use } \\
\text { of the SNS } \\
\text { - Receipt of the physical stock of the } \\
\text { SNS } 6,000 \text { metric tons of wheat }\end{array}$ & $\begin{array}{l}\text { Establishment of a financial stock } \\
\text { valued at } € 2,800,000 \text {, or the } \\
\text { cyuivalcnt of } 14,000 \text { mctric tons of } \\
\text { grain } \\
\text { Strengthening the CSA's stock } \\
\text { [naintenance capacities by procuring } \\
\text { maintenance equipment }\end{array}$ \\
\hline $\begin{array}{l}\text { - Initial ood Security } \\
\text { Observ }\end{array}$ & $\begin{array}{l}\text { Establishment and normal functioning of } \\
\text { the OS } \Lambda \text { (half-yearly bulletins on food } \\
\text { sectrity) }\end{array}$ & & $\begin{array}{l}\text { Establishment of an institutional } \\
\text { mechanism responsible for organizing } \\
\text { emergency food aid } \\
\text { - Strengthening of the tools for } \\
\text { identifying and monitoring food } \\
\text { vulnerability:-revision of } \\
\text { methodologies, computer training of } \\
\text { staff, and introdtetion of a } \\
\text { Geographical Information System } \\
\text { (SlG) } \\
\text { Establishment and coordination of the } \\
\text { new national framework for } \\
\text { consultation on food security }\end{array}$ & $\begin{array}{l}\text { Expanded monitoring of populations } \\
\text { al sisk to cover vulnerable groups in } \\
\text { peri-urban areas } \\
\text { - Preparation of a national food } \\
\text { vilnerability map }\end{array}$ \\
\hline
\end{tabular}

CInternational Monetary Fund. Not for Redistribution 


\begin{tabular}{|c|c|c|c|c|}
\hline OI-144 & Priority actions carried out in 2001 & Priority actions planned for 2900 & Prkonity actions carried out in 20012 & Priority actions plamed for 2003 \\
\hline $\begin{array}{l}\text { - Strengonnection } \\
\text { betweet and } \\
\text { attenua actions } \\
\text { aimed rovement in } \\
\text { food se } \\
\\
\text { - Implenogram of the } \\
\text { Microptgency- } \\
\text { HLL A] } \\
\\
\text { Implenograms of } \\
\text { the Focission (CSA) }\end{array}$ & $\begin{array}{l}\text { A program with } 132 \text { microprojects (EU } \\
\text { financing) is now being carried out by the } \\
\text { AEMP } \\
\text { - Conduct of programs on: Rural } \\
\text { Development and Food Security, } \\
\text { Community Support for Food Security, } \\
\text { Special Adrar Project }\end{array}$ & & $\begin{array}{l}\text { Conduct of a study on food } \\
\text { consumption standards and hab its in } \\
\text { Mauritania } \\
\text { Formation of the regional network on } \\
\text { standerds for in Formation gathering on food } \\
\text { security } \\
\text { Creation of a website on food security in } \\
\text { Mauritania } \\
\text { - Execulion of a self-finaneed CSA } \\
\text { program cowering } 85 \text { mi croprojects } \\
\text { Conduct of } 176 \text { migroprojects in the } \\
\text { context of the Food For Work (FFW) } \\
\text { program of the WFP } \\
\text { Formation of the regional network an } \\
\text { standards for information gathering on food } \\
\text { security } \\
\text { Execution by 1he AEMP of a program } \\
\text { with } 71 \text { microprojects on food secirity } \\
\text { fithanced by the European Union }\end{array}$ & $\begin{array}{l}\text { - Periodic monitering of cross-bor der } \\
\text { flows of food products } \\
\text { Strengthening human capacities of } \\
\text { the Observatory for the analysis and } \\
\text { processing of data, by carrying out a } \\
\text { training plan } \\
\text { Monitoring the impact of food } \\
\text { security actions } \\
\text { Study of local strategies for } \\
\text { adjusting to food crises } \\
\text { Strengtheting of the Observatory's } \\
\text { documertation center } \\
\text { Building the publication capacities } \\
\text { of the OSA } \\
\text { Cartying out } 38 \text { mictopr ojects on } \\
\text { food secutity in the amount of } \\
\text { UM } 681 \text { million in the context of the } \\
\text { PACSA. } \\
\text { Conduct of } 231 \text { microprojects in the } \\
\text { FFW program financed by the WFP }\end{array}$ \\
\hline $\begin{array}{l}\text { Environumer } \\
-\quad \text { Presers: } \\
\text { Implemational } \\
\text { converonment and } \\
\text { of the INE }\end{array}$ & $\begin{array}{l}\text { Climatic changes: Studies on attenuating } \\
\text { emissions of greenhouse gasses, workshop } \\
\text { to validale these studies, initiation of } \\
\text { vulnerability and adaptation sutdies on the } \\
\text { bases of two sectors deemed the most } \\
\text { vulnerable (agricuitural and littoral } \\
\text { environment) }\end{array}$ & $\begin{array}{l}\text { - Conivention on. Biological Diversity: } \\
\text { validation of the national program and } \\
\text { strategy, Clinatic Changes: issuanco } \\
\text { of reports to the Convention } \\
\text { Secretariat in Bonn, Rainfed areas: } \\
\text { inventory of birds, PAN/LCD: } \\
\text { finalization of program, organization } \\
\text { of the validation forum, and } \\
\text { information campaign }\end{array}$ & $\begin{array}{l}\text { - Convention on Biolegical Diversity: } \\
\text { validation of the national program and } \\
\text { strategy, Climatic Changes; issuance } \\
\text { of reports to the Convention Secretariat } \\
\text { in Born, Rainfed areas: inventory of } \\
\text { birds, PAN/LCD: finalization of } \\
\text { program, organization of the validation } \\
\text { forum, and information campaign }\end{array}$ & \\
\hline $\begin{array}{ll} & \text { Implentam to } \\
\text { expandural areas }\end{array}$ & $\begin{array}{l}\text { - Organization of a campaign to expand } \\
\text { butane use with oasis associations, and } \\
\text { establishment of butane use units in raral } \\
\text { areas } \\
\text { Areas reforested (Ptoject Oasis and PARP), } \\
\text { consolidation of } 35 \text { reforestation sites (198 } \\
\text { bectares), mechanical stabilization of dunes } \\
\text { (totaling 6,800 meters in length, PGRINP) }\end{array}$ & $\begin{array}{l}\text { PARP: butane use campaigns in } 5 \\
\text { communities in Brakna and } 10 \text { in } \\
\text { Tagant } \\
\text { - Preparation of a raster plan for } \\
\text { providing firewood and charcoul to } \\
\text { major urban contors }\end{array}$ & $\begin{array}{l}\text { Continuation of butane use campaign } \\
\text { Prnject submitted to Interministerial } \\
\text { Commitle for approval }\end{array}$ & $\begin{array}{l}\text { Continuation of butane use } \\
\text { campaign } \\
\text { - Continued efforts as regards } \\
\text { reforestation, forest protection, and } \\
\text { aerial seeding }\end{array}$ \\
\hline
\end{tabular}

CInternational Monetary Fund. Not for Redistribution 


\begin{tabular}{|c|c|c|c|c|}
\hline Ob-04 & Priority actions carrted out in 2,101 & Priority actions planned for $\mathbf{2 0 0 2}$ & Priority actions carried out In 2002 & Priority actions planned for 2003 \\
\hline $\begin{array}{l}\text { Inctusiaent a a } \\
\text { dimensielopment } \\
\text { projects }\end{array}$ & $\begin{array}{l}\text { Envircnmental impact study conducted for } \\
\text { the UDP and the PASK }\end{array}$ & $\begin{array}{l}\text { Reforestation carnpaign involvitig } \\
4,500,000 \text { plants }(10,500 \text { hectares), } \\
\text { maintenance of } 21,000 \mathrm{~km} \text { of } \\
\text { frebreaks, aerial seeding in the } \\
\text { northern parts of Trarza, Brakna, and } \\
\text { Tagant } \\
\text { Environmental impact study of } \\
\text { programs and projects }\end{array}$ & $\begin{array}{l}\text { - Reforestation campaign involving } \\
4,500,000 \text { plants (10,500 hectares), } \\
\text { maimtenance of } 21,000 \mathrm{~km} \text { of firebreatk, } \\
\text { nerial seeding in the nothern parts of } \\
\text { Trarza, Brakna, and Tagant }\end{array}$ & $\begin{array}{l}\text { - Protection of grazing land ( } 15,000 \\
\text { hectares of firebreak to be developed } \\
\text { in Hodh E1 Gaarbi, Hodh } E 1 \\
\text { Chragui, Assaba, Guidimakha, } \\
\text { Gorgol, Brakna, and Traze, of } \\
\text { which } 11,040 \mathrm{~km} \text { by the MDRE, } \\
\text { defensive preparedness } \\
\text { Environmental impact study of } \\
\text { programs and projects }\end{array}$ \\
\hline $\begin{array}{l}\text { Urban devel } \\
\text { Ensure relopment } \\
\text { resuitinn with all } \\
\text { stakeho } \\
\text { Preparaevelopment } \\
\text { ! policy I } \\
\text { Revisions on land } \\
\text { tenure t to property } \\
\text { ownersin the part of } \\
\text { the pod } \\
\text { Revisiourban } \\
\text { manageadastre and } \\
\text { SDAl) } \\
\text { Developentution of } \\
\text { city strad NDB and } \\
\text { for the itals }\end{array}$ & $\begin{array}{l}\text { Preparation of an urban development poticy } \\
\text { letter } \\
\text { Publication of Decree } 2000 / 85 \\
\text { implementing Ordinance } 83 / 127 \text { on } \\
\text { property ownership and government land } \\
\text { reform } \\
\text { Finalization of SDAU reports for NKC and } \\
\text { NDB } \\
\text { Validation of the concerted strategies for } \\
\text { the cities of NKC, NDB, and Kaeddi }\end{array}$ & $\begin{array}{l}\text { - Adoplion of provisions on land tenure } \\
\text { - Approval of SDAU reports for NKC } \\
\text { and NDB } \\
\text { Gradual development of city } \\
\text { strategies for the other regional } \\
\text { capitals } \\
\text { Annual program of the ADU }\end{array}$ & $\begin{array}{l}\text { Approval of SDAU reports for NKC } \\
\text { and NDB }\end{array}$ & 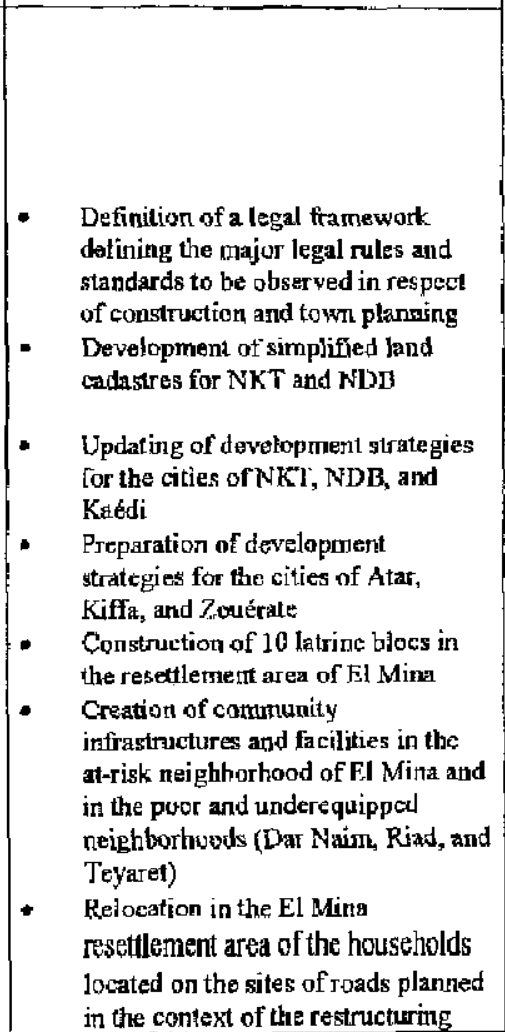 \\
\hline & & & & $\begin{array}{l}\text { Techrical studics for the } \\
\text { construction of a waste removal } \\
\text { center } \\
\text { Technical studies for the } \\
\text { restructuring and improvement of } \\
\text { the Noulakichort nonindustrial fishing } \\
\text { ajea }\end{array}$ \\
\hline
\end{tabular}

CInternational Monetary Fund. Not for Redistribution 
Initiation of the organizational and financia audits of SOCOGIM, the DCL, the AMM and the rturticipalities of NDB and NKC, as well as audits of poverty reduction activities in urban areas

\section{Launch of the study on the priority} investment program

Restructuring $p$ lan for the al-risk neighborhood of EA Mina, initiation of the subdivision of the resetzlement zone, SPP and DPP study of investment programs, establishmenl of the

Resettlement' Compensation Cotntni ssion

Restructuring plan, subdivision of relocation ares, SPP and DPP study of investment programs, establishment of

Relocation/Compensation Comrnission

Continuation and consolidation of the Twine pilot phase, with the construction of 460 housing units and the granting of 505 housing credits and 793 economic rredits

\section{Study of mictufinance for housing}

Finalization of the organizational and
financial audits of SOCOGIM, the DCL, the AMM, and the munticipalities of Noradhibou and Nouskchat

- Finalization of the study on the priority investment program

- Operations to prepare for restructuring of the kébbé of $\mathrm{E}$ Mina, identification of entitled parties initiation of detaited lechnical studies (DPPs) for basic infrastructure and equipment

\section{Annual progratm}

Organizational and financial audits of the CUN and the 9 municjpalities - Recruitment of technical assistance teatms to work with SOCOGIM, the DCL, and the AMM

Finglizalion of the study on the priority investment program

- Preparition of DPPs (roads, watex electricity, community equipment, sasitation)

Preparation of site for relocated houstholds; relocation thereof

\section{Annual program of the UDP}

75 subsidized housing units completed and 625 undey construction, granting of $1,7301 \mathrm{GAs}$, publication of procedures manuals (housing, community access, microfinance)

\section{Twine project pilot phase
Twintal}

- Initiation of "Twize-Rajaz" operation: enthaticing value of local traterials for builditig subsidized housing units

Initiation of a program for promoting the use of cut stone for masonry construction and urban improvements: paving of

passage ways, roads, road borders, pubjic passage ways, roads, road borders, pubitic
squares. Pilot operation in the citics of Atrr, Aioun and Kiffa

CInternational Monetary Fund. Not for Redistribution 


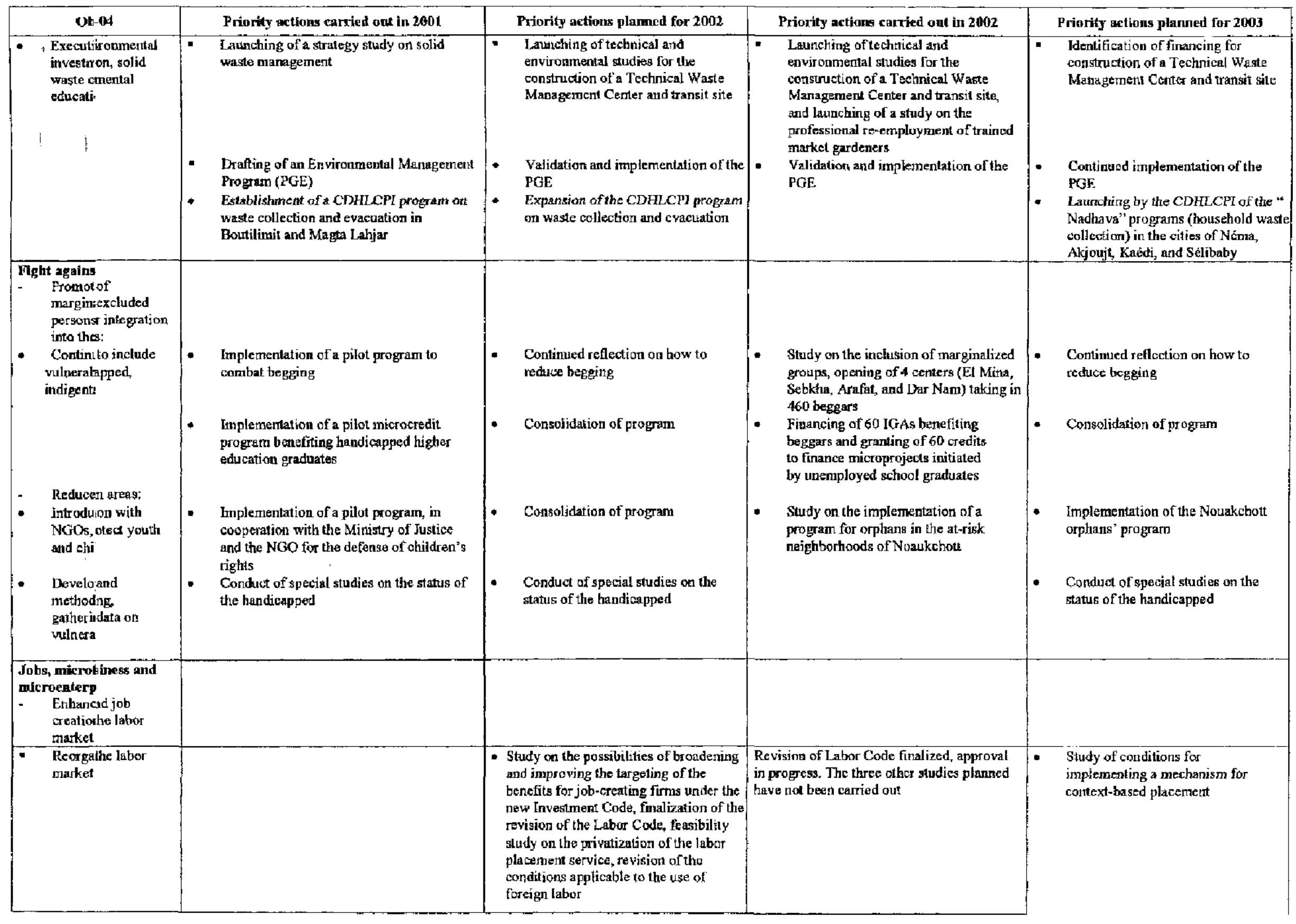

CInternational Monetary Fund. Not for Redistribution 


\begin{tabular}{|c|c|c|c|c|}
\hline $\mathbf{O H}-\mathbf{0 4}$ & Priority actions carried out in 2091 & Priority actions planned for 2002 & Priority actions carried out in 2002 & Priority actions planned for 2003 \\
\hline $\begin{array}{l}\text { Promotredit on the } \\
\text { part of yen it } \\
\text { particul } \\
\text { Consolsion of } \\
\text { microcel support to } \\
\text { MFIs }\end{array}$ & $\begin{array}{l}\text { Launch of studies on the introduction of a } \\
\text { strategic franework for microenterprise } \\
\text { and microfinance } \\
\text { Implementation of the annual program of } \\
\text { the CDHLCPI, the SECF, etc, in favor of } \\
\text { MFIs, Mobilization of saving by MFIs, } \\
\text { over UM } 120 \text { nillion in credil }\end{array}$ & $\begin{array}{l}\text { Introduction of a strategic framework } \\
\text { fot tnictocnterprise and microfinance } \\
\text { - Imptementation of the annual } \\
\text { program of the CDHLCPI, the SECF, } \\
\text { etc., in favor of MFIs }\end{array}$ & 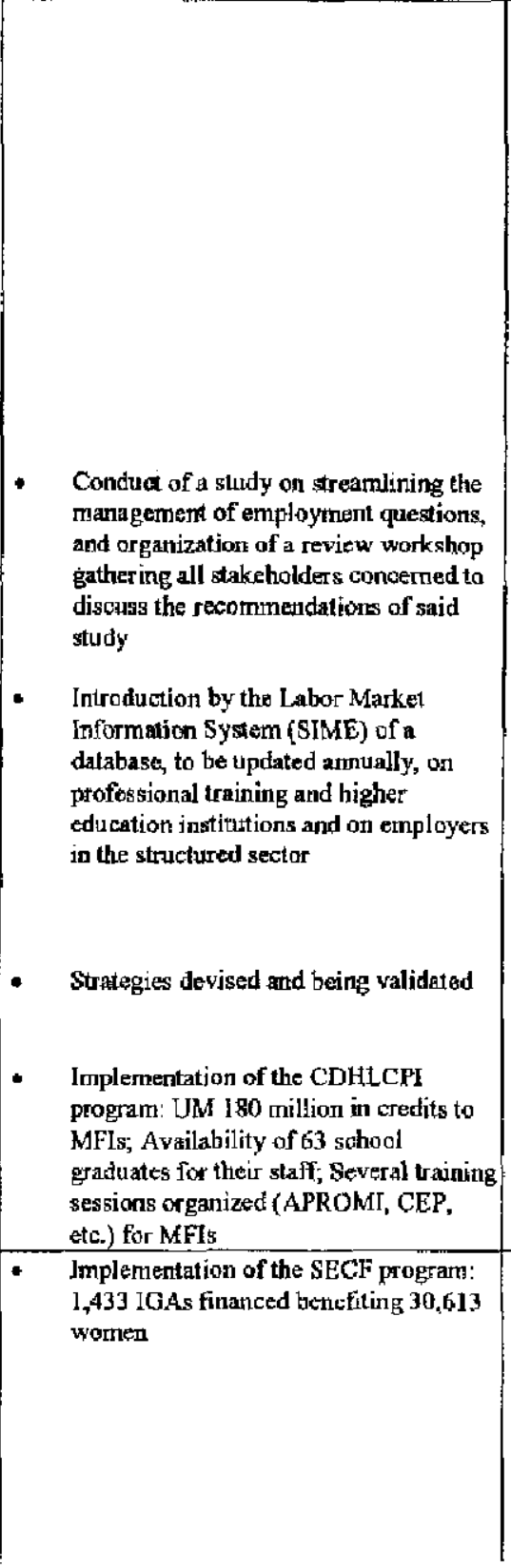 & 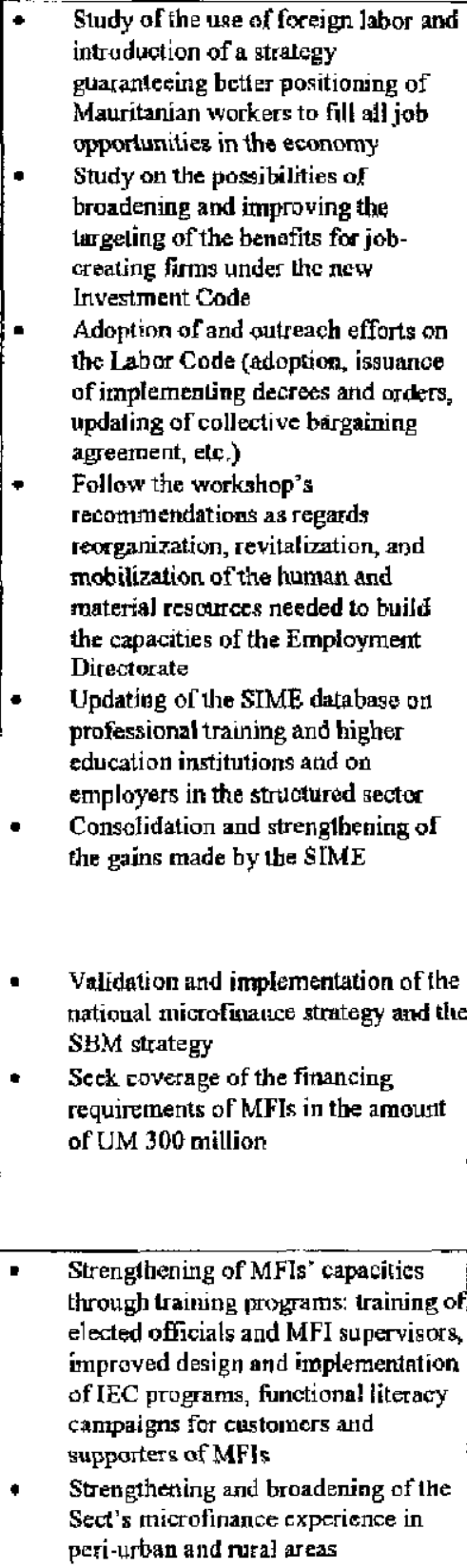 \\
\hline
\end{tabular}

CInternational Monetary Fund. Not for Redistribution 


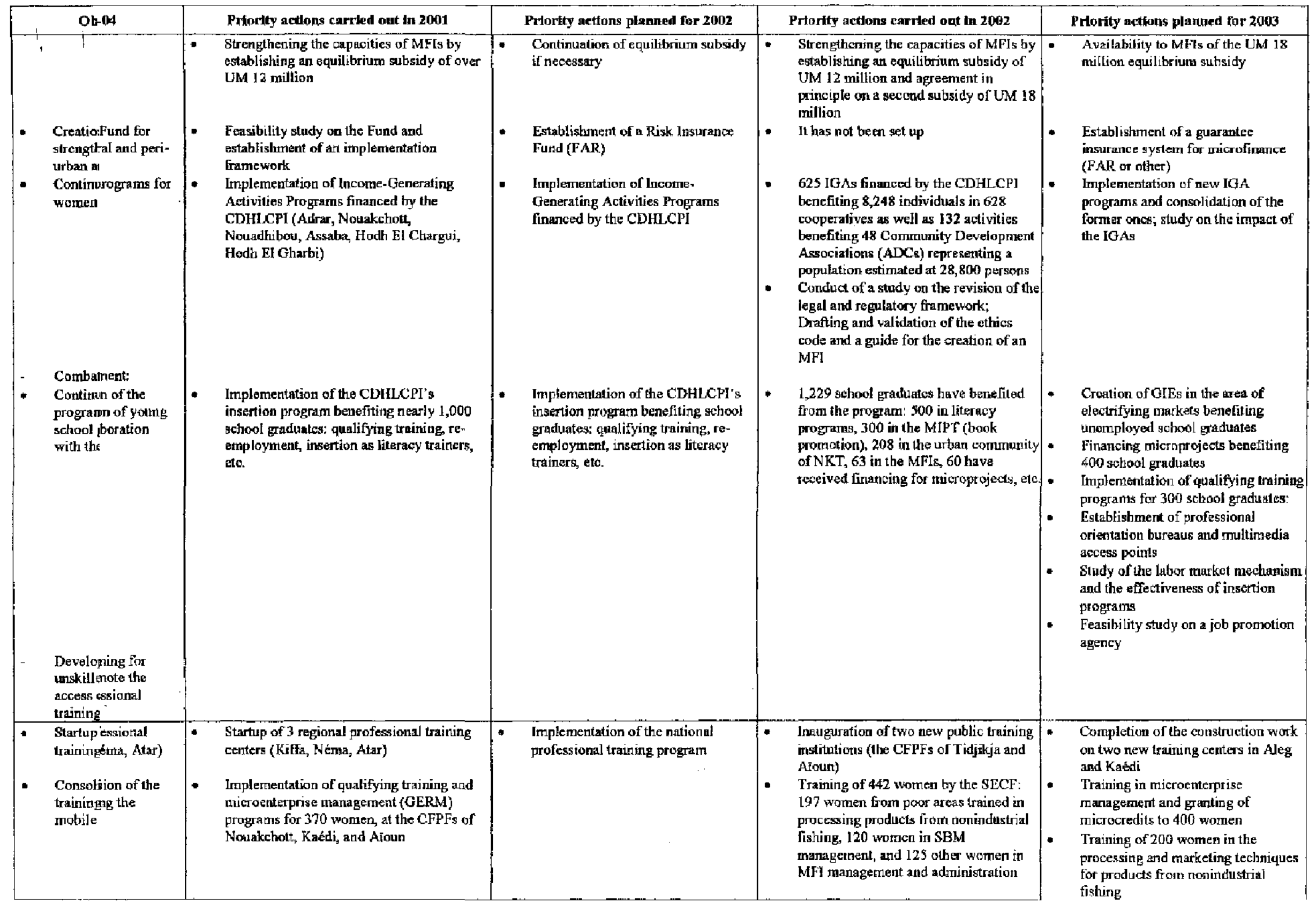

CInternational Monetary Fund. Not for Redistribution 


\begin{tabular}{|c|c|c|c|c|}
\hline Oh-114 & Priority actions carried ond in 2001 & Priarity actions plamed for 2602 & Priarity metions carried out in 2002 & Priority aclions planned for $\mathbf{2 0 0 3}$ \\
\hline $\begin{array}{l}\text { - Promotiness, and } \\
\text { microer } \\
\text { Draftintion of the } \\
\text { Crafts C } \\
\text { - Establides Chamber }\end{array}$ & $\begin{array}{l}\text { - Strenghening of CFPFs and introdiction of } \\
\text { an inoentive system for trainers } \\
\text { - Implementation of qualifying training } \\
\text { programs in Selibaby, Kiffa, Rosso, Atar. } \\
\text { Nouadhibou, and Nouakchotl }\end{array}$ & $x^{2}$ & 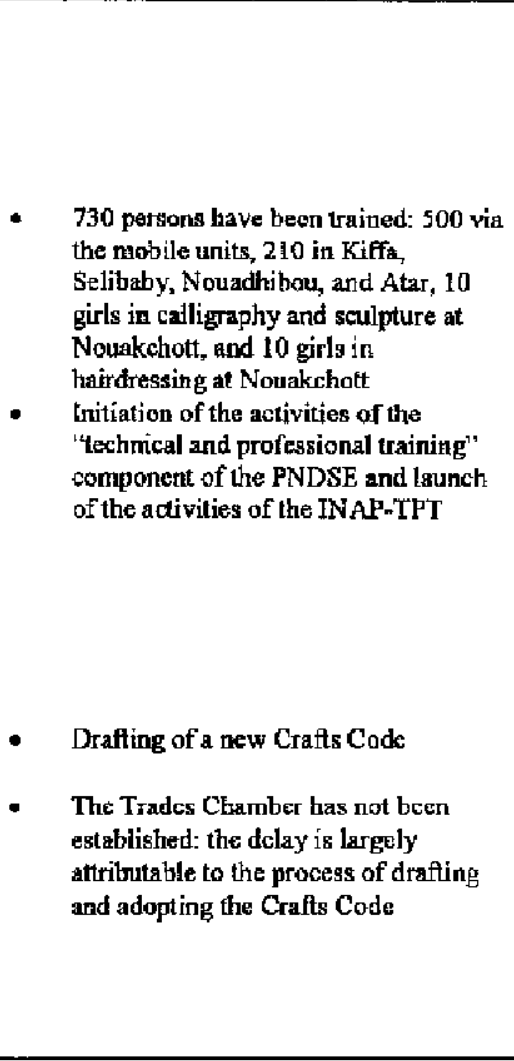 & $\begin{array}{l}\text { - Design and implementation of a } \\
\text { qualifying training program } \\
\text { benefiting poor wonnen in peri-urban } \\
\text { and nisal areas } \\
\text { - Implementation of the professional } \\
\text { training program for } 5,000 \text { persons } \\
\text { throughort the entire national } \\
\text { territory } \\
\text { Contimued efforts to enhance the } \\
\text { quality and quantity of professionals } \\
\text { in professional training } \\
\text { Startup of new trajning methods } \\
\text { (afternation, apprenticeships) in } \\
\text { various institutions } \\
\text { Introduction of a system for } \\
\text { monitoring TPT recipients } \\
\text { Study on the informal sector } \\
\text { - Implementation of the new Crafts } \\
\text { Code } \\
\text { Establishment of the organizational } \\
\text { schema and the Chamber } \\
\text { Creation of } 10 \text { new savings and } \\
\text { credit banks for crafts } \\
\text { Implementation of a training } \\
\text { progran for tratitional craftsmen } \\
\text { Development of an export strategy } \\
\text { for crafts products }\end{array}$ \\
\hline \multicolumn{5}{|c|}{ FUCUS 3: DEVELOPMENT OF HUMAN RESOURCES AND EXPANSION OF BASIC SERVICES } \\
\hline $\begin{array}{l}\text { Education, li } \\
\text { Basic educat } \\
\text { - Increase to the } 1^{\text {st }} \\
\text { year of } 100 \text { percent } \\
\text { by } 200 \text { sgional and } \\
\text { gender ss: }\end{array}$ & & & & \\
\hline $\begin{array}{l}\text { Make se full cycle } \\
\text { the stanbuilding } \\
1,533 \text { chabifituting } \\
564 \text { oth }\end{array}$ & $\begin{array}{l}\text { - Ideatification of schools to be completed, } \\
\text { construction of } 900 \text { elassrooms, latenching } \\
\text { of the program to build } 250 \text { other } \\
\text { classrooms, corstruction of enclosures for } \\
90 \text { schools } \\
\text { Recruitment of } 1,300 \text { instructors and } \\
\text { revision of the annual recruitment objective } \\
\text { (650) under the PNDSE }\end{array}$ & $\begin{array}{l}\text { - Continuation of the cetastruction } \\
\text { program } \\
\text { - Continuation of the recruitment } \\
\text { program }\end{array}$ & $\begin{array}{l}4,54 \text { teachers rectuiled; } 1,300 \text { now } \\
\text { receiving training }\end{array}$ & $\begin{array}{l}\text { Expansion of the number of schools } \\
\text { offering conpiete cycles } \\
\text { Construction of } 900 \text { classeoms } \\
\text { Opening of } 200 \text { canteens } \\
\text { Study af the causes of school dropout } \\
\text { by girls and the awarding of prizes to } \\
\text { latreates } \\
\text { Increase the number of bilingual } \\
\text { teachers Training of } 1,300 \text { teachers, } \\
\text { 650 for the start of the } 7003 / 04 \text { school. } \\
\text { year and } 6500 \text { for } 2004 / 05\end{array}$ \\
\hline
\end{tabular}




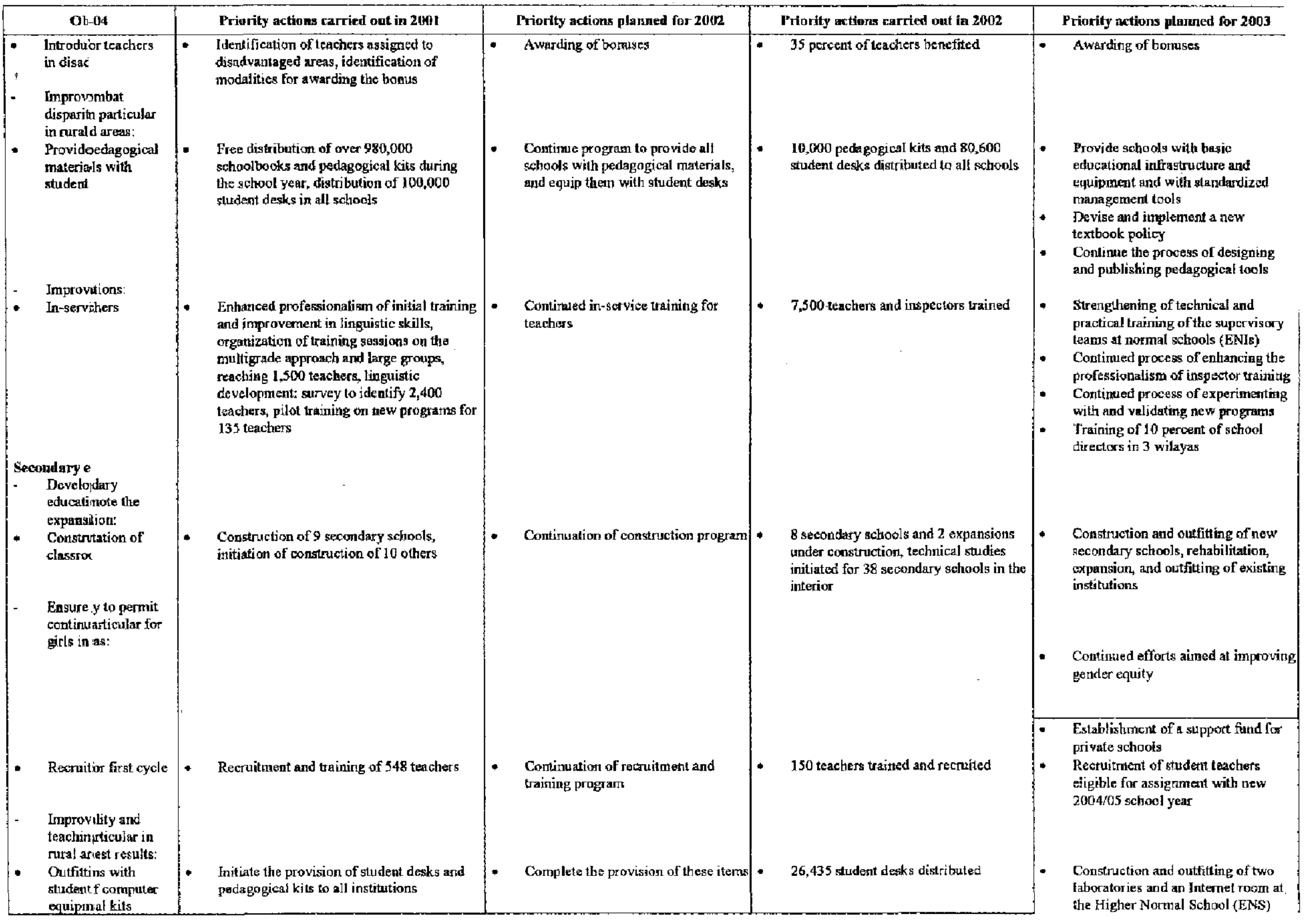

CInternational Monetary Fund. Not for Redistribution 


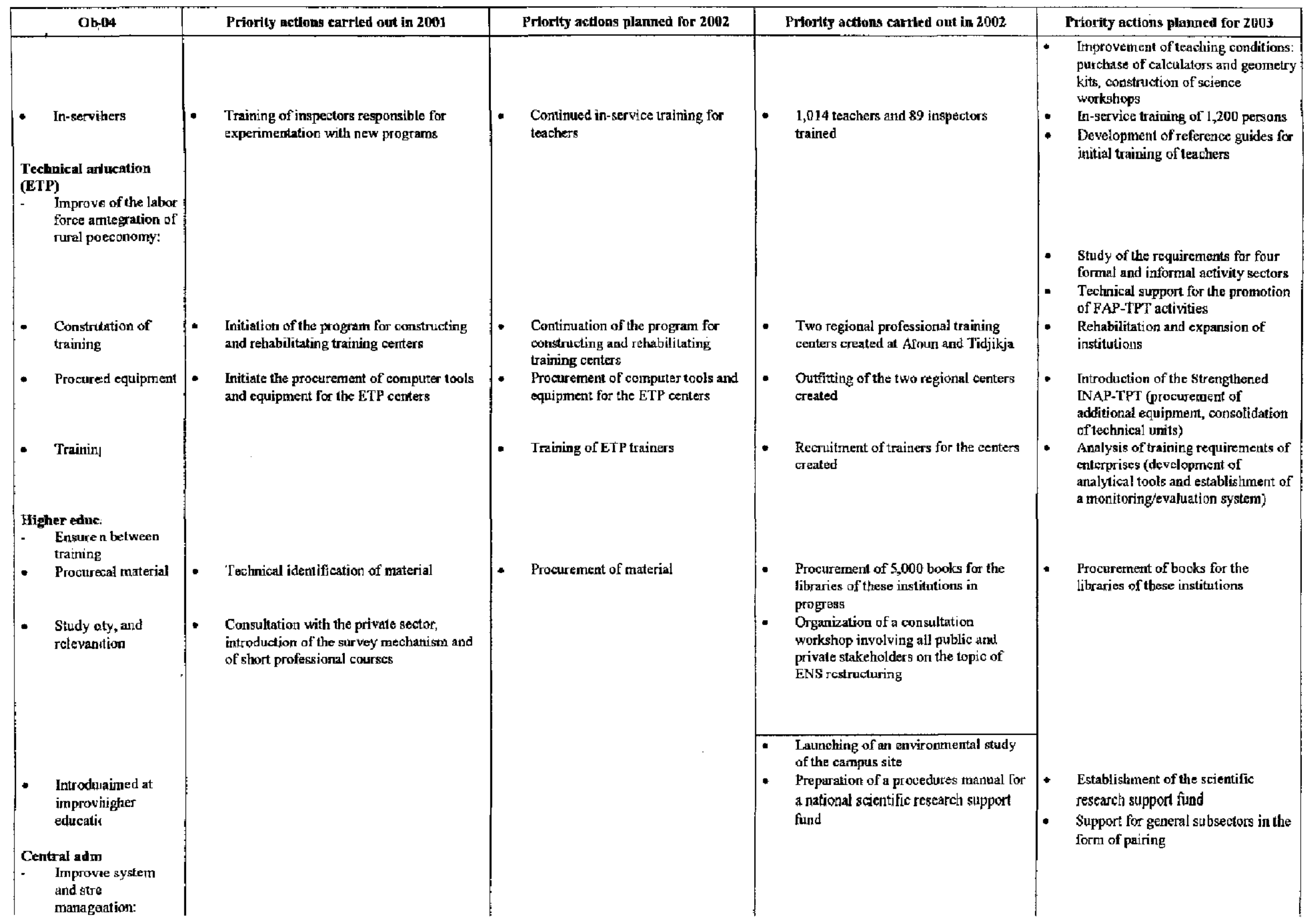

CInternational Monetary Fund. Not for Redistribution 


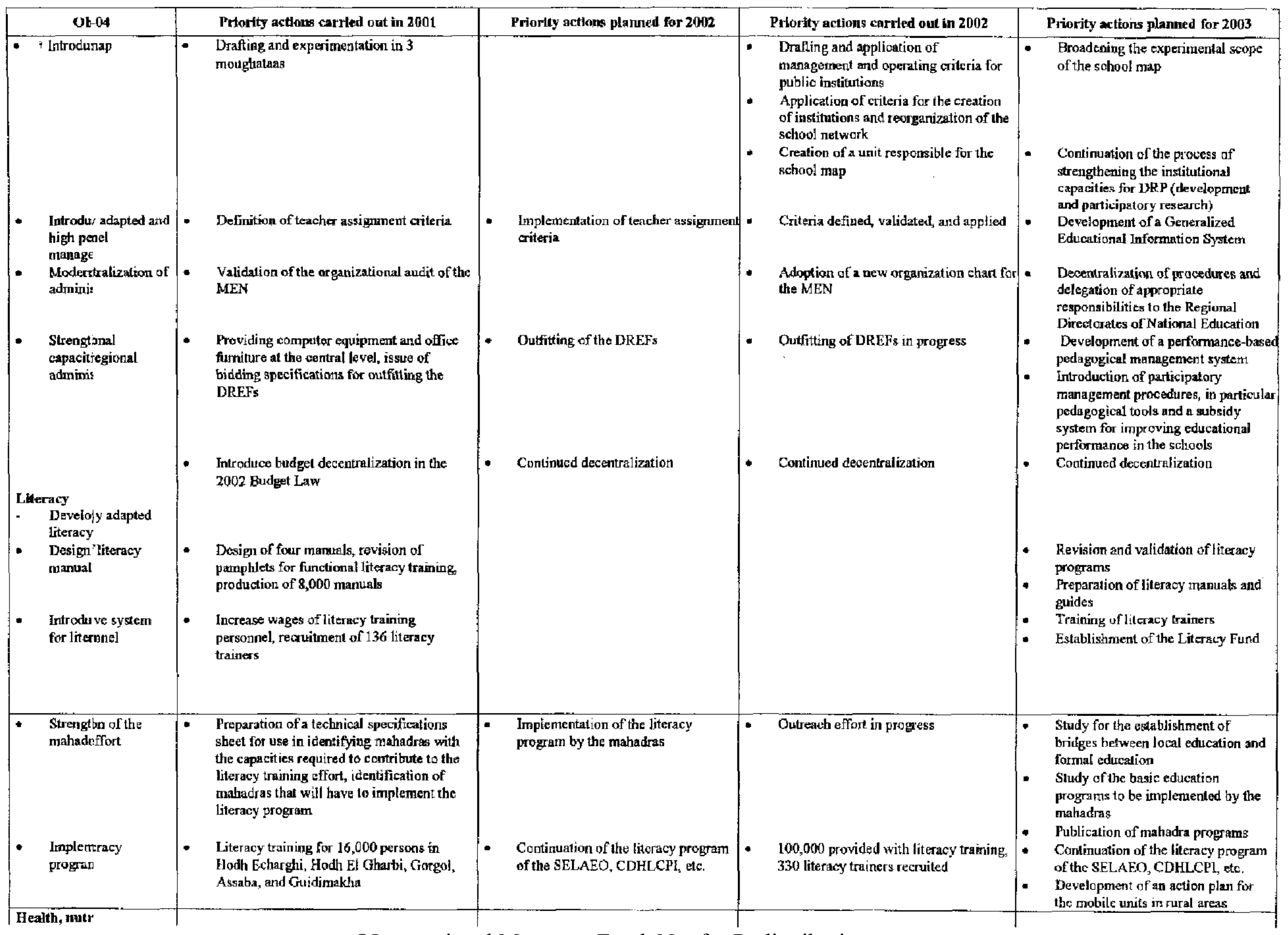

CInternational Monetary Fund. Not for Redistribution 


\begin{tabular}{|c|c|c|c|c|}
\hline Ot-04 & Priority actions carried out in 2001 & Priority actions planned for 2002 & Priority actions cannited out in 20002 & Priority actions planned for 2003 \\
\hline $\begin{array}{l}\text { - Improves provided } \\
\text { to the pr the poorest, } \\
\text { and rec and } \\
\text { mortali the major } \\
\text { disease } \\
\text { Increastimum } \\
\text { packag ensuring } \\
\text { maternh and } \\
\text { addrestlth problems, } \\
\text { at all lepyramid }\end{array}$ & $\begin{array}{l}\text { Training of } 12 \text { surgeons, initiation of } \\
\text { training of } 12 \text { pediatricians and } 12 \\
\text { obstetries-gynecology specialists, } \\
\text { recruitment of } 25 \text { physicians, } 15 \\
\text { pharmacists, recruitment of } 90 \\
\text { paramedicals and } 93 \text { naid wife assistants, } \\
\text { recruitment in progress of } 57 \text { medical and } \\
\text { paramedical persomel }\end{array}$ & $\begin{array}{l}\text { - Construction of } 54 \text { heslth posts in the } \\
\text { wilayes of Assaba, the two Hodhs, } \\
\text { Guidinakha, Brakna, Trarza, and } \\
\text { Gorgol, and a Health Center in } \\
\text { Nowakchot, rehabilitation and } \\
\text { outfitting of } 7 \text { regional hospitals }\end{array}$ & 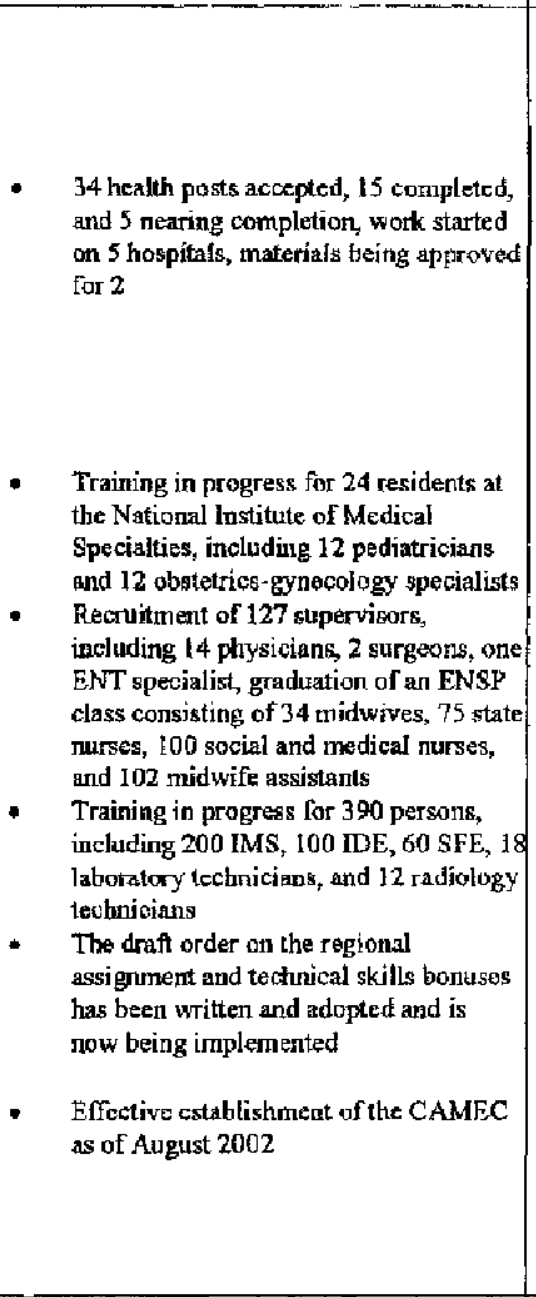 & $\begin{array}{l}\text { - Coustruction of } 80 \text { health posts and } 3 \\
\text { health centers, and continuation of } \\
\text { ongoing tehabilitation of } 7 \text { regional } \\
\text { hespitals } \\
\text { Outfitting of } 7 \text { regional hospitals and } \\
\text { the CHN outpaljent clinic } \\
\text { Initiating construction work on a } \\
\text { cardiac surgery unit at the Cleikh } \\
\text { Zayed Hospital } \\
\text { Continued health training of } 390 \\
\text { health personnel at the ENSP } \\
\text { Initiation of a new olass of surgeons } \\
\text { at the INSM, and continued training } \\
\text { of pediatricians and gynecologists } \\
\text { - Continued training of medical } \\
\text { persongel } \\
\text { Continued implementation of the } \\
\text { regional assignment and techntical } \\
\text { skills bonuses } \\
\text { Preparation of a development policy } \\
\text { ot humant resources } \\
\text { Outfitting of the medication quality } \\
\text { control laboratory } \\
\text { Development of a medication policy }\end{array}$ \\
\hline $\begin{array}{l}\text { Securithe cost } \\
\text { recovetalth care } \\
\text { levcls } \\
\text { Study a a system for } \\
\text { coveringents, in } \\
\text { cooperartments } \\
\text { concer } \\
\text { Involvirs and } \\
\text { commure decisions }\end{array}$ & $\begin{array}{l}\text { - Study appraising and revising the } \\
\text { provisions governing the cost recovery } \\
\text { system } \\
\text { - Implennentation of a study on indigence, } \\
\text { experimentation with sharing obstetrical } \\
\text { risk in Notakchott } \\
\text { Revision of the legal provisions relating to } \\
\text { the management of tegional and outlying } \\
\text { heatth facilities }\end{array}$ & $\begin{array}{l}\text { Development of mulual insurance for } \\
\text { health risks } \\
\text { - Subsidization and covering costs of } \\
\text { indigents }\end{array}$ & $\begin{array}{l}\text { Development of certain forms of } \\
\text { mutual insurance on ant experimental } \\
\text { basis } \\
\text { Drafting of regulatory provisions on the } \\
\text { SRC which set forth proportions for the } \\
\text { coverage of indigent patients at the } \\
\text { health facility level }\end{array}$ & $\begin{array}{l}\text { Continued contracting and } \\
\text { broadening of experience with flat- } \\
\text { rate fee for risk sharing to one region } \\
\text { in additjon to Nouakchot } \\
\text { Launching of indigence project at } \\
\text { the level of the two Hodlo: } \\
\text { application of the decree and orders } \\
\text { relating to the SRC and calling for } \\
\text { caring for indigends at no charge }\end{array}$ \\
\hline
\end{tabular}

CInternational Monetary Fund. Not for Redistribution 


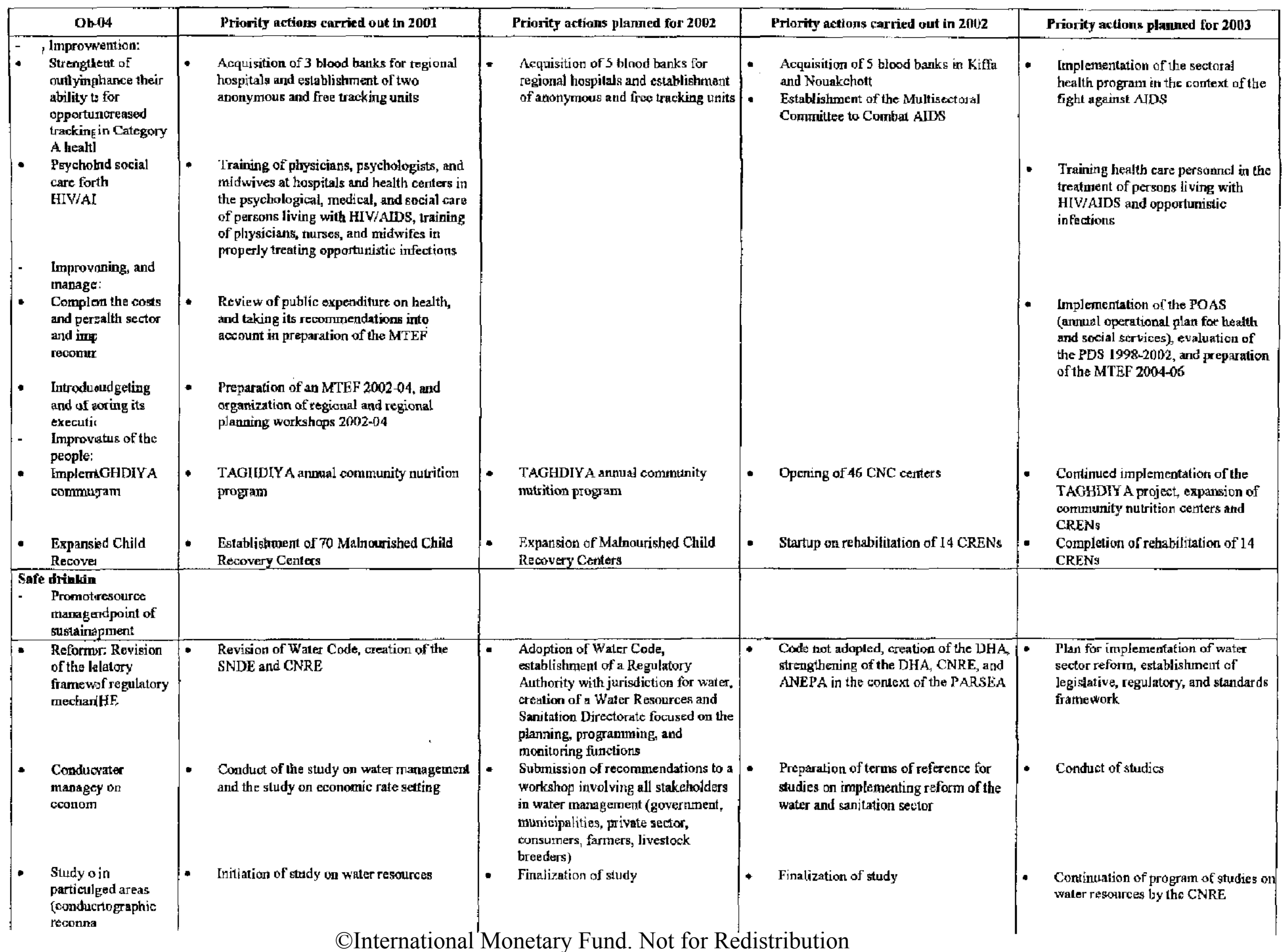




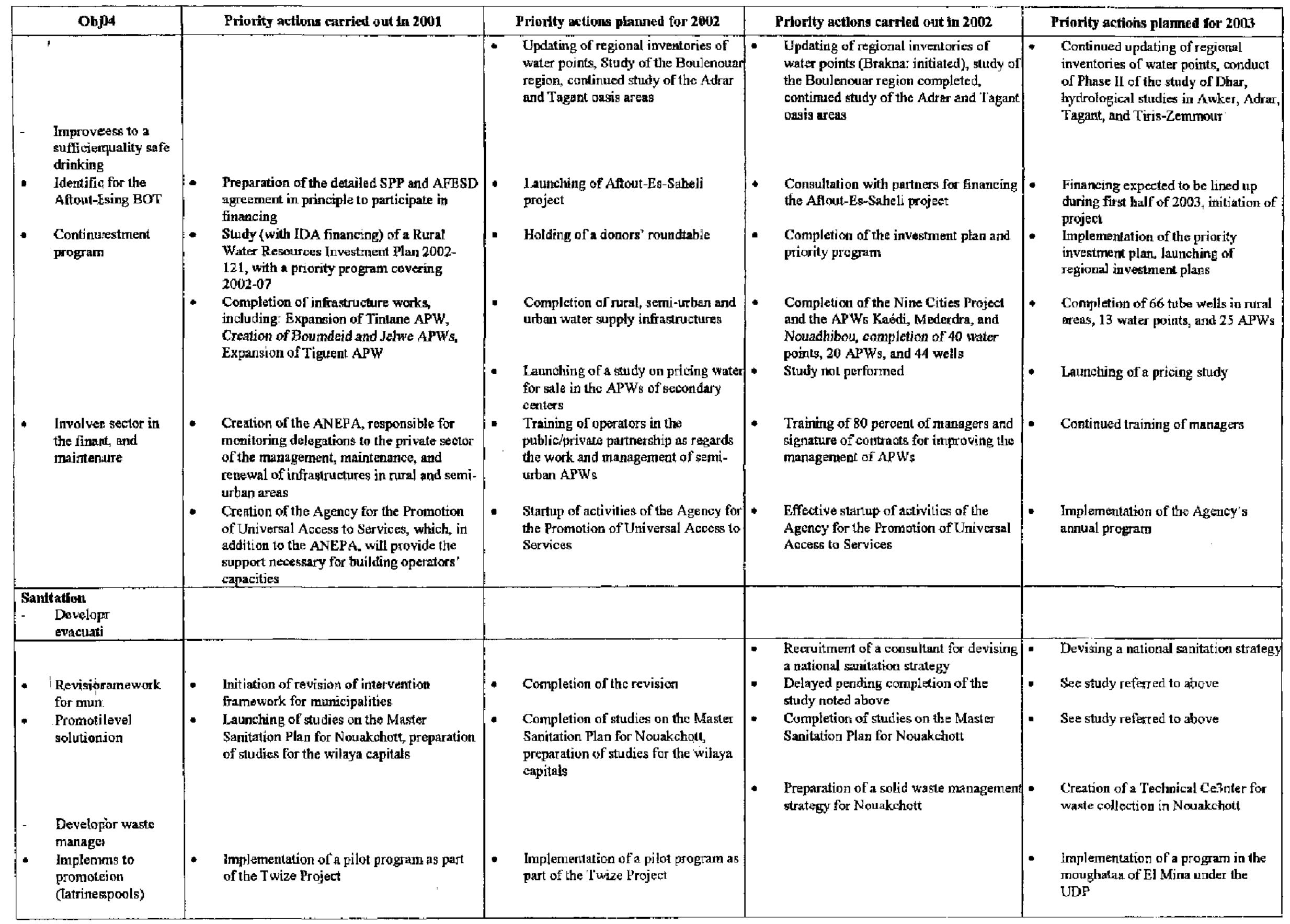

CInternational Monetary Fund. Not for Redistribution 


\begin{tabular}{|c|c|c|c|c|}
\hline Ob-04 & Prhority actions carried out in 2001 & Priority actions plawned for 2002 & Priority actions carried out in 2602 & Priority actions planned for 2003 \\
\hline 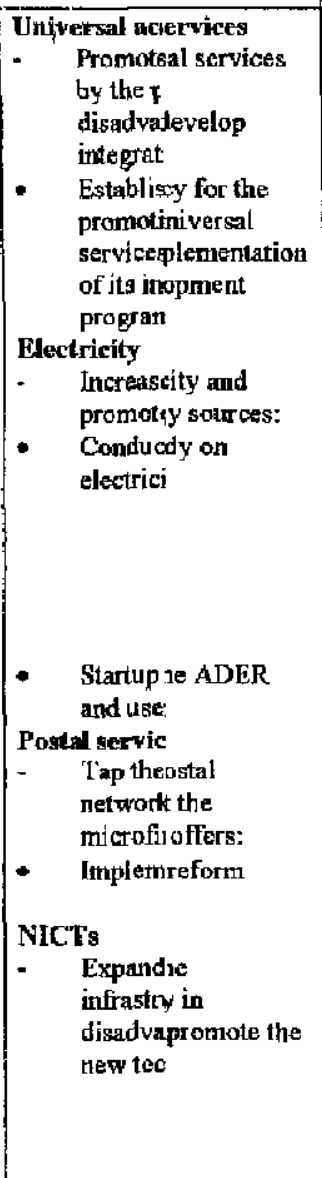 & $\begin{array}{l}\text { - Rural electricity: Preliminary rate study } \\
\text { associfted with the operation to disseminate } \\
\text { 3,000 photovoltajc kits conducted by } \\
\text { ADER; Urban electricity: Privalization of } \\
\text { SOMELEC will make it possible to } \\
\text { guarantee rater aceessible to the most } \\
\text { disadvantaged urban groups } \\
\text { Starthp of operations of the ADER anc user } \\
\text { cooperatives }\end{array}$ & $\begin{array}{l}\text { - Startup of activities of the Agency for } \\
\text { the Promotion of Universal Access to } \\
\text { Services } \\
\text { - Emplementation of the } 3,000 \text { kits } \\
\text { program } \\
\text { ADER annual program }\end{array}$ & $\begin{array}{l}\text { - Bidding specifications completed for the } \\
\text { 3,000 kits operation, performance of } \\
\text { work in progress; development of an } \\
\text { investment plan for rusal electrification } \\
\text { ADER annual program }\end{array}$ & 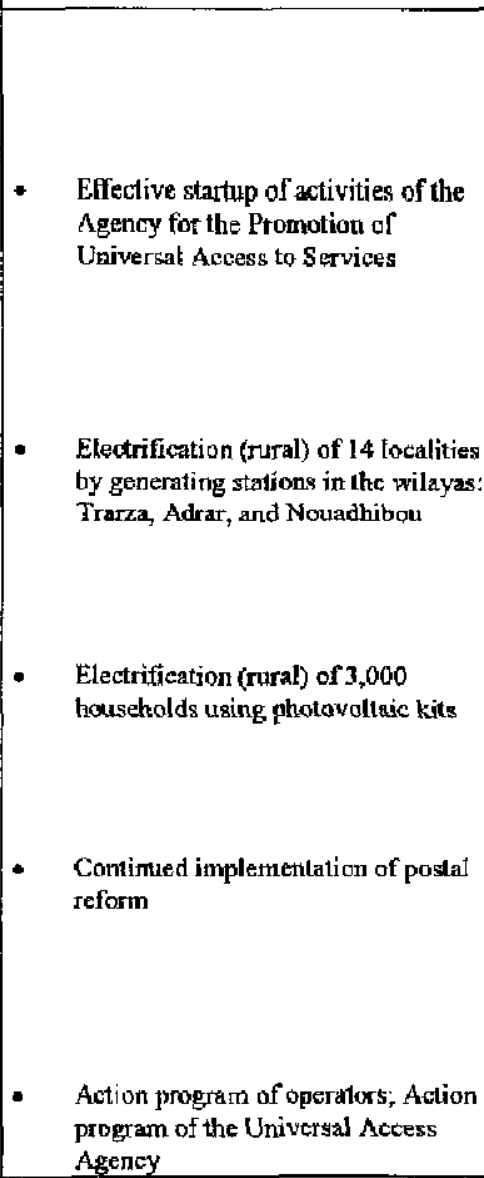 \\
\hline $\begin{array}{l}\text { Establisarent legal } \\
\text { ctameurs for NICT } \\
\text { operator } \\
\text { - Supportf urban and } \\
\text { rurail teltext of } \\
\text { povertyns }\end{array}$ & $\begin{array}{l}\text { - } \begin{array}{l}\text { Preparation of an NICT development } \\
\text { strategy }\end{array}\end{array}$ & $\begin{array}{l}\text { Adoption and implementation of the } \\
\text { NICT development strategy } \\
\text { - Implementation of an initial program } \\
\text { (see Universal Access Agency) }\end{array}$ & $\begin{array}{l}\text { Adoption of the NICT developtncnt } \\
\text { strategy } \\
\text { Conduct training activities for the } \\
\text { Outreach Administration } \\
\text { - Establishment of the CyberCommune } \\
\text { of Aioun }\end{array}$ & $\begin{array}{l}\text { Implementation of the NICT } \\
\text { development strategy } \\
\text { - Implementation of an initial program } \\
\text { (see Universal } A \text { coess Agency) }\end{array}$ \\
\hline & 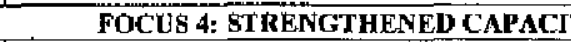 & TIES FOR GREATER EFFICIENCY WN T & TIIE FIGET AGAINSI POVERTY & \\
\hline $\begin{array}{l}\text { Justice } \\
\text { - Sitrengthen nd bring } \\
\text { justice closer tizen: } \\
\end{array}$ & & & & \\
\hline
\end{tabular}

CInternational Monetary Fund. Not for Redistribution 


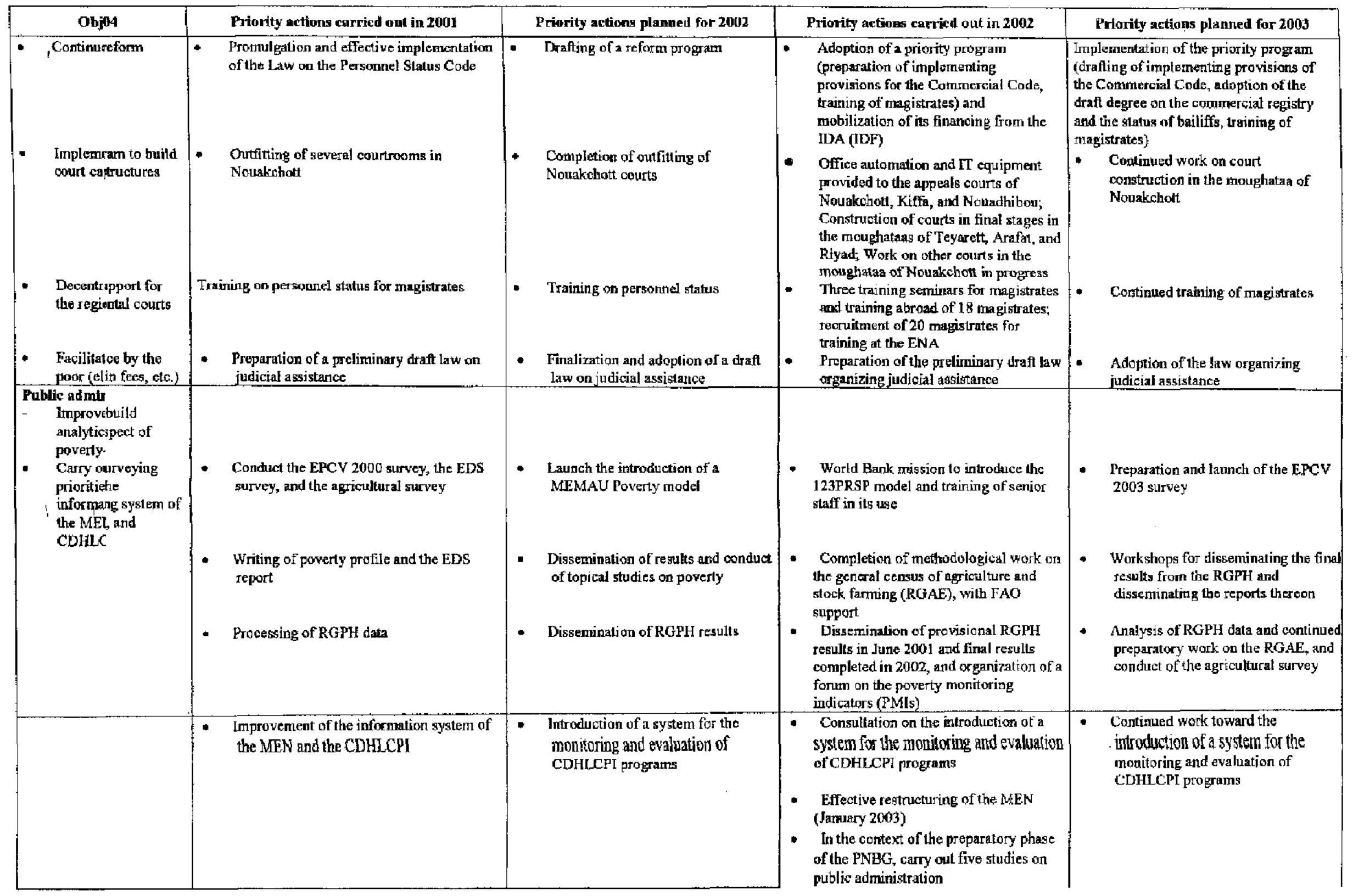

CInternational Monetary Fund. Not for Redistribution 


\begin{tabular}{|c|c|c|c|c|}
\hline Ob-4 & Priority actions carried out in 2001 & Priority actions planned for 2002 & Prhorly actlous carried out in 2002 & Priority actions planned for 2003 \\
\hline ' & & & 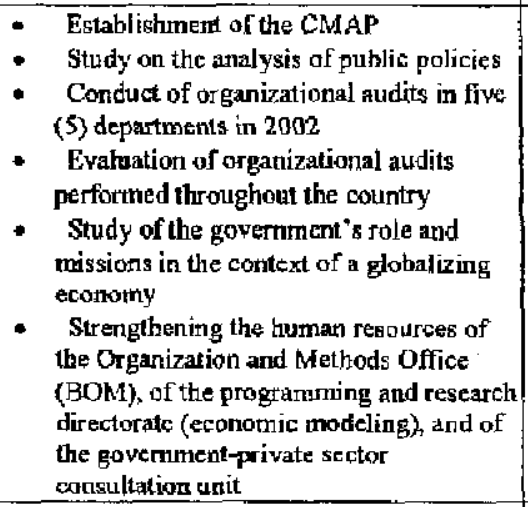 & \\
\hline $\begin{array}{l}\text { Locil goven } \\
\text { Strengl of local } \\
\text { govern them the } \\
\text { resourcquit their } \\
\text { respons } \\
\text { Innplerral taxation } \\
\text { feform }\end{array}$ & - Eroadening of municipal taxation powers & - Continuation of the reform & 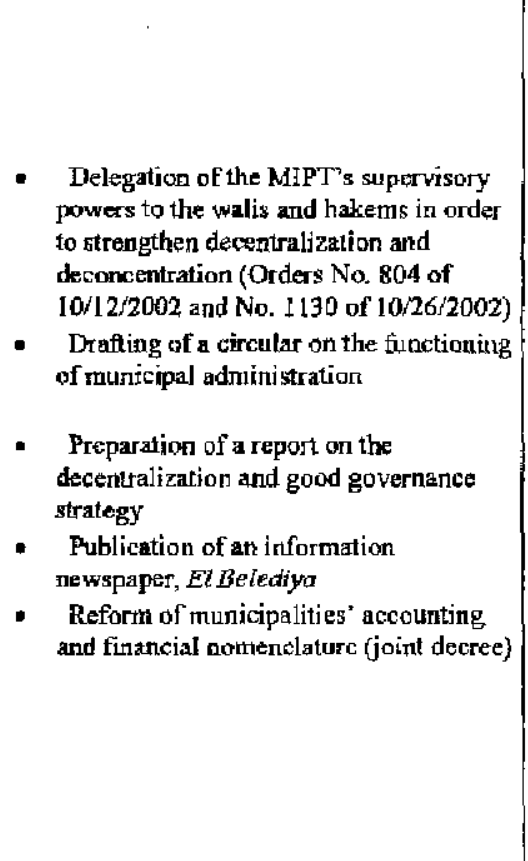 & 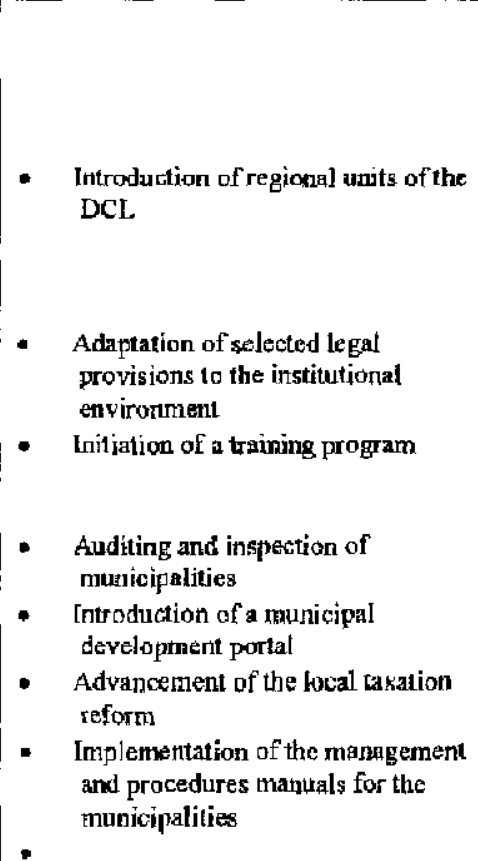 \\
\hline $\begin{array}{l}\text { Sirengthal capacities } \\
\text { in the maintenance } \\
\text { of collee }\end{array}$ & $\begin{array}{l}\text { Introduction of support programs for the } \\
\text { municipalities (PADDEM, PAC) }\end{array}$ & $\begin{array}{l}\text { Startup of the UDP, contpletion of } \\
\text { PADDEM pilot experments, } \\
\text { inplementation of KfW 3, } \\
\text { implementation of first phase of PAd } \\
\text { projecl (GTZ) }\end{array}$ & $\begin{array}{l}\text { - Effective startup of the UDI } \\
\text { - Completion of the PADDEM } \\
\text { - Implemtentation of KfW } 3 \text { and of the } \\
\text { PAC } \\
\text { - Increase in government transfers and } \\
\text { significantit increase in RDF (UM } 600 \\
\text { million) }\end{array}$ & $\begin{array}{l}\text { Reform of the RDF and infroduction } \\
\text { of credit activation mechanisms } \\
\text { - Inplementation of the municipal } \\
\text { contrasts (urban municipalities) } \\
\text { Initiation of a project to support } \\
\text { decentralization (German } \\
\text { cooperation) }\end{array}$ \\
\hline
\end{tabular}




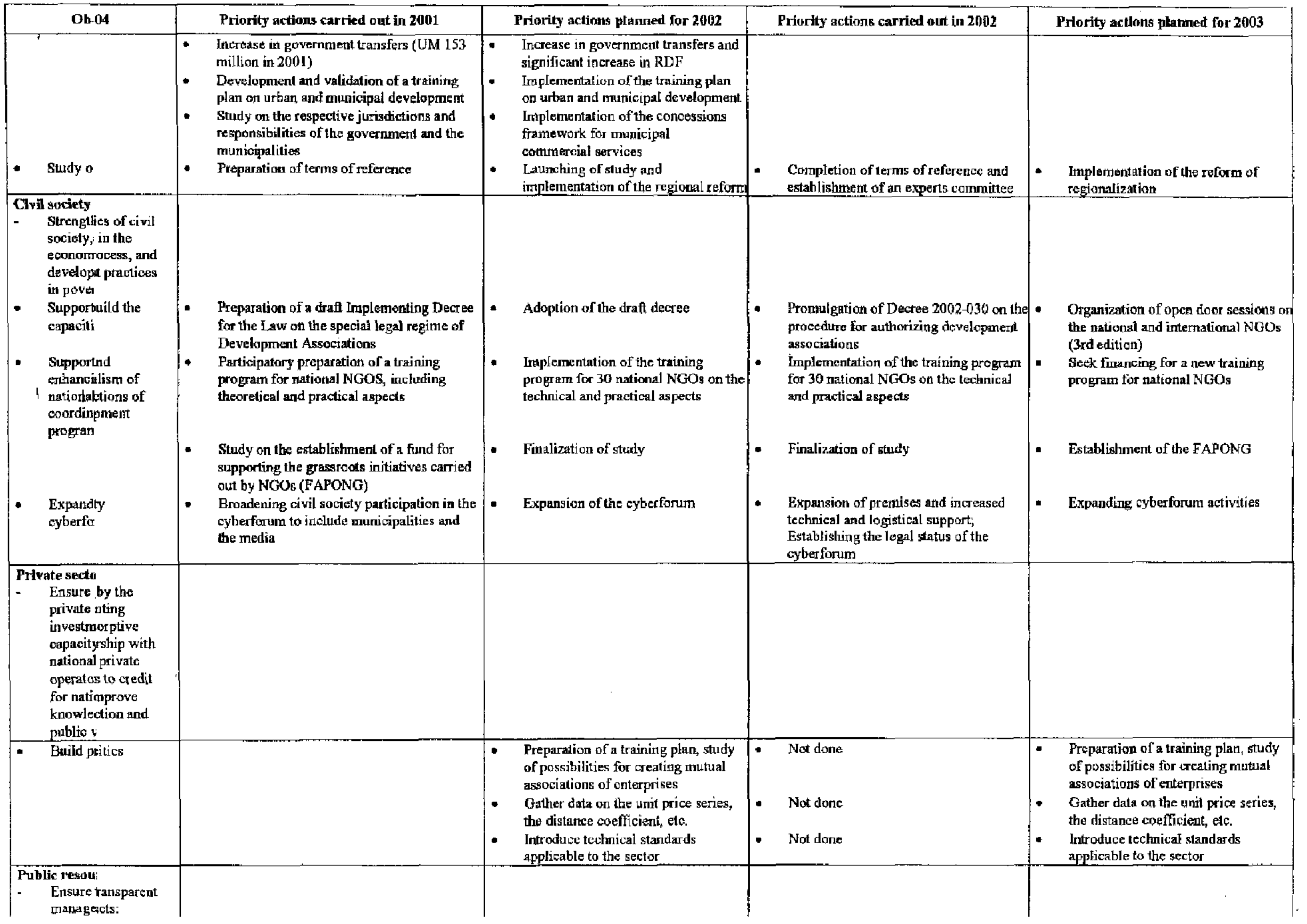

CInternational Monetary Fund. Not for Redistribution 


\begin{tabular}{|c|c|c|c|c|}
\hline Ob-64 & Priority actions carried out in 20101 & Priority actions plammed for 2002 & Primrity actions carried out in 2002 & Priority actions planned for 2003 \\
\hline 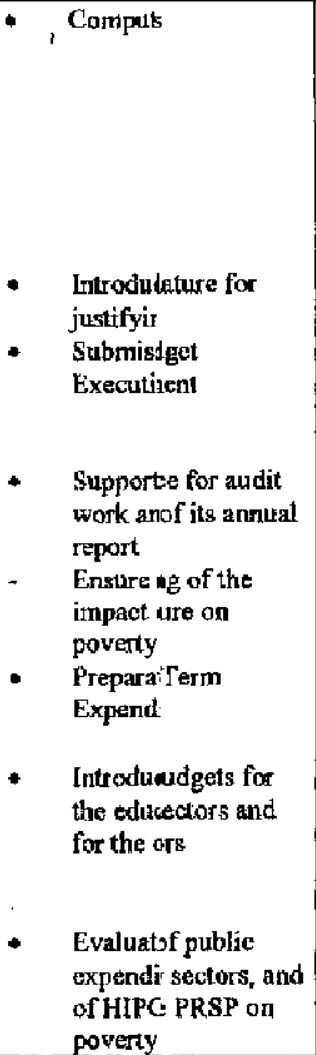 & $\begin{array}{l}\text { - Techrical studies on automating the payroll } \\
\text { - Computerize pensions: preparation of a } \\
\text { computerization program } \\
\text { - Preparation of terns of reference and } \\
\text { bidding specifications for computerizing } \\
\text { expenditure on goods and services } \\
\text { Introctuction of a nomenclature for } \\
\text { justifying documentation } \\
\text { Establishment of commissions lo prepare } \\
\text { the draft law, acloption of a settlement law } \\
\\
\text { Provide the Audit Office with human and } \\
\text { material resources under the } 2001 \text { Budget } \\
\text { Law }\end{array}$ & $\begin{array}{l}\text { Preparation of a global MTEF } \\
\text { Introduction of program budgets for } \\
\text { inirail development, urban } \\
\text { development, and transportation } \\
\text { infrastructure } \\
\text { Introduction of an eyaluation systern }\end{array}$ & 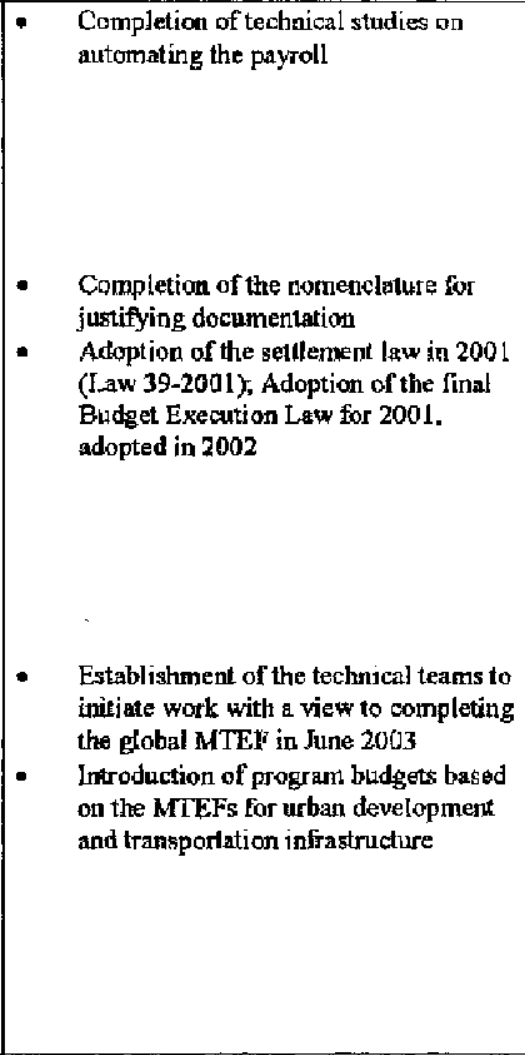 & $\begin{array}{l}\text { - Support to the Audit Office for audit } \\
\text { activities; Provide the Audit Office } \\
\text { with human and logistical resources } \\
\text { - Preparation of a global MTEF to } \\
\text { serve as the basis for preparing the } \\
\text { 2004 Budget Law } \\
\text { Finalization of the MTEF for sural } \\
\text { development; preparation of the } \\
\text { MTEFs Jor the water resources, rural } \\
\text { electrification and nonindustrial } \\
\text { fishing sectors } \\
\text { Fvaluation of the impact of } \\
\text { expenditure in the heal th and } \\
\text { education sectors }\end{array}$ \\
\hline $\begin{array}{l}\text { Implementatund } \\
\text { evahuation, im, and } \\
\text { further npda } \\
\text { - Ensure ig and } \\
\text { regular isP: } \\
\text { ImplemSP through } \\
\text { Regionson Progeams } \\
\text { (RPRPs }\end{array}$ & $\begin{array}{l}\text { Pronulgation of the Orientation Law on } \\
\text { Poverty Reduction }\end{array}$ & $\begin{array}{l}\text { - Oradual implementation of the } \\
\text { Regional Poverty Reduction } \\
\text { Rrograms (RPRPs) }\end{array}$ & $\begin{array}{l}\text { - Preparation of two methodological } \\
\text { tools: the "Methodological Guide" and } \\
\text { the "toolhox" }\end{array}$ & $\begin{array}{l}\text { - Gradual implementation of the } \\
\text { RPRPs in the first } 5 \text { wilayas }\end{array}$ \\
\hline $\begin{array}{l}\text { Repeat I mechanism } \\
\text { used for to ensure } \\
\text { rigorous }\end{array}$ & $\begin{array}{l}\text { Repeat of the institutional mechunism used } \\
\text { for the PRSP: theetings of technical } \\
\text { oommittees and groups, preparation of } \\
\text { topic-based reports } \\
\text { Continued work by topic-based technical } \\
\text { committees and groups } \\
\text { Workshops and meetings to monitor PRSP } \\
\text { implemertation held in January } 2002\end{array}$ & $\begin{array}{l}\text { - Introduction of un integrated system } \\
\text { for PRSP monitoring and evaluation } \\
\text { - Contimued work by topic-based } \\
\text { technical comanjtees and groups } \\
\text { Workshops and meetings to monitor } \\
\text { PRSP implementation }\end{array}$ & $\begin{array}{l}\text { - Concuct of a study on the introduction } \\
\text { of an integrated sysilom for PRSP } \\
\text { monitoring and evaluation } \\
\text { - Continued work by topic-based } \\
\text { technical committees and goups } \\
\text { Workshops and meetings to montitor } \\
\text { PRSP implementation planned for } \\
\text { February-March } 2003\end{array}$ & $\begin{array}{l}\text { Introduction of an integrated systern } \\
\text { for PRSP monitoring and evaluation } \\
\text { - Continued work by topic-based } \\
\text { lechmical committees and groups } \\
\text { Workshops and meetings to nionitor } \\
\text { PRSP implementation }\end{array}$ \\
\hline
\end{tabular}

CInternational Monetary Fund. Not for Redistribution 


\begin{tabular}{|c|c|c|c|c|}
\hline Ob.04 & Priority actions carried out in 2001 & Priarity actions planned for 2001 & Priorty actions carried out in $2 \mathrm{nO2}$ & Priority actions pkanned for 2003 \\
\hline $\begin{array}{l}\text { - Developed } \\
\text { commum the PRSP } \\
\text { - Participluation of } \\
\text { the PR5 }\end{array}$ & $\begin{array}{l}\text { Preparation of report on PRSP } \\
\text { implementation in } 2001 \text {, augmented on the } \\
\text { basis of new poverty data } \\
\text { Development of a concerted } \\
\text { communication strategy on the PRSP }\end{array}$ & $\begin{array}{l}\text { Preparation of report on PRSP } \\
\text { implementation in } 2002 \\
\text { Validation and implementation of } \\
\text { the communication strategy } \\
\text { - Preparation of the Evaluation } \\
\text { Outlme }\end{array}$ & $\begin{array}{l}\text { Finalization of the report on PRSP } \\
\text { implementation in } 2002 \text { scheduled for } \\
\text { March } 2003 \\
\text { Dissenination of documentation on the } \\
\text { PRSP using multiple media (CD-ROM, } \\
\text { paper, etc.) } \\
\text { Introdicction of an integrated system for } \\
\text { PRSP monitoring and evaluation }\end{array}$ & $\begin{array}{l}\text { Preparation of repert on PRSP } \\
\text { implementation in } 2003 \\
\text { Validation and implementation of } \\
\text { the communication strategy } \\
\text { - Introduction of an integrated system } \\
\text { for PRSP nonitoring and evaluation }\end{array}$ \\
\hline
\end{tabular}




\section{Annex 3: Program of Priority Actions and Costs ${ }^{3}$}

This amnex corresponds to Annex 4 of the Report on PRSP Implementation in 2001, corrected to reflect the MTEFs for education, health, urban development, and transportation infrastructure that have recently been prepared. MTEFs for the other priority sectors (rural development and water resources) as well as a global MTEF are currently in preparation.

\begin{tabular}{|c|c|c|c|c|c|}
\hline & & 200 & & 2003 & 2004 \\
\hline Priority areas & Priority actions & Proj. & Actual & Proj. & Proj. \\
\hline Focus 1: Accelerated and & d redistributive growth (costs in millio) & ns of oug & guiyas) & & \\
\hline & & 381 & 70 . & 9,080 & 18915 \\
\hline Macroeconomic framework stabilized & & PMI & PM & PM & PM \\
\hline $\begin{array}{l}\text { Deepening of reforms in the legal and } \\
\text { judicial incertives framework for business }\end{array}$ & & 100 & & 200 & 300 \\
\hline Promotion of mining activities & & & & 280 & 435 \\
\hline $\begin{array}{l}\text { Strengthening the integration of the fisheriesp } \\
\text { sector into the national economy }\end{array}$ & Pelagic fishing port & $\mathrm{PM}$ & PM & PM & PM \\
\hline & Autonomous port of Nouadhibou & & & 300 & 300 \\
\hline & Tanit port & & & 1,410 & 1,880 \\
\hline & $\begin{array}{l}\text { Optimal achievement of growth } \\
\text { potential of nonindustrial fishing: jobs, } \\
\text { value added, spillover effect5 }\end{array}$ & PM & PM & PM & PM \\
\hline & Rational mathagement of resources & 50 & & 60 & 100 \\
\hline & $\begin{array}{l}\text { Training and retraining in nonindustrial } \\
\text { fishing trades }\end{array}$ & 150 & & 200 & 200 \\
\hline Infrastructure supporting growth & $\begin{array}{l}\text { Nouakchott-Nouadhibou road } \\
\text { Nouakchott airport } \\
\text { Rosso-Boghé road }\end{array}$ & 81 & 70 & $\begin{array}{l}2,700 \\
1,080 \\
2.850\end{array}$ & $\begin{array}{r}8,100 \\
7600\end{array}$ \\
\hline Focus 2: Growth & $h$ anchored in the economic sphere of $t$ & he poor & & & \\
\hline Rural development & & 3,677 & 3,108 & 5,224 & 6,567 \\
\hline $\begin{array}{l}\text { Improved production, productivity, and } \\
\text { diversification }\end{array}$ & $\begin{array}{l}\text { Agricultural water supply } \\
\text { improvements in the river valley }\end{array}$ & & & 74 & 717 \\
\hline & $\begin{array}{l}\text { Diversification of agricultural } \\
\text { procuction }\end{array}$ & PM & PM & PM & PM \\
\hline & $\begin{array}{l}\text { Consolidation and expansion of the } \\
\text { Fand tenure reform program }\end{array}$ & 100 & 75 & 100 & 100 \\
\hline & $\begin{array}{l}\text { Program for research on and } \\
\text { dissemination of improved seeds }\end{array}$ & 100 & 75 & 150 & 200 \\
\hline Environment & Promotion of forestry subsectors & 77 & 58 & 250 & 270 \\
\hline & Butane use program & 300 & 225 & 450 & 450 \\
\hline & $\begin{array}{l}\text { Consolidation of oasis development } \\
\text { activities }\end{array}$ & 150 & 113. & 250 & 250 \\
\hline Development of livestock subsector & Development of milk production & 80 & 60 & 100 & 180 \\
\hline & Implementation of the Farming Code & PM & PM & PM & PM \\
\hline & $\begin{array}{l}\text { Improved livestock production for } \\
\text { export }\end{array}$ & & & 100 & 100 \\
\hline & $\begin{array}{l}\text { Increase in number of vaccination parks } \\
\text { and veterinary stations }\end{array}$ & 50 & 38 & 100 & 100 \\
\hline
\end{tabular}




\begin{tabular}{|c|c|c|c|c|c|}
\hline \multirow[b]{2}{*}{ Priority areas } & \multirow[b]{2}{*}{ Priority actions } & \multicolumn{2}{|c|}{2002} & \multirow{2}{*}{ 2003 } & \multirow{2}{*}{2004} \\
\hline & & Proj. & Actual & & \\
\hline & $\begin{array}{l}\text { Selection of well adapted breeds and } \\
\text { extension work }\end{array}$ & 100 & 75 & 200 & 250 \\
\hline $\begin{array}{l}\text { Targeted programs to combat poverty in } \\
\text { rural areas }\end{array}$ & & 1,400 & 1,400 & 1,600 & $2, \overline{000}$ \\
\hline Rural inffastructure (dirt roads, dams, etc.) & & 1,200 & 900 & 1,700 & $1, \overline{800}$ \\
\hline Urban development & & 6,850 & 550 & 22,514 & 15,273 \\
\hline \multirow[t]{6}{*}{ Improvement of living conditions in cities } & $\begin{array}{l}\text { Program to equip and enhance the } \\
\text { viability of at-risk neighborhoods in } \\
\text { Nouakchott }\end{array}$ & 2,068 & 130 & 3,512 & 1,150 \\
\hline & $\begin{array}{l}\text { Other infrastncture and equipment in } \\
\text { Nouakchott }\end{array}$ & 2,087 & & 13,012 & 10,899 \\
\hline & Improved new urban areas & 500 & & & 45 \\
\hline & $\begin{array}{l}\text { Priority investment program for other } \\
\text { regional capitals }\end{array}$ & 1,000 & & 4,602 & 2,344 \\
\hline & Microcredit for housing and IGAs & 500 & 420 & 450 & 450 \\
\hline & $\begin{array}{l}\text { Promotion of economic activities and } \\
\text { employment }\end{array}$ & 495 & & 674 & 174 \\
\hline Institution building in the sector & $\begin{array}{l}\text { Strengthened capacities of } \\
\text { administrations and municipalities }\end{array}$ & 200 & & 224 & 211 \\
\hline \multicolumn{6}{|c|}{ Focus 3: Development of human resuurces and expansion of basic services } \\
\hline Education & & 15,989 & 5,624 & 8,494 & 12,057 \\
\hline \multicolumn{6}{|l|}{ Program to expand education } \\
\hline \multirow[t]{4}{*}{ Basic } & Recruitment of teachers & & 284 & 236 & 343 \\
\hline & $\begin{array}{l}\text { Indemnity for teachers assigned to } \\
\text { disadvantaged areas }\end{array}$ & & 78 & 240 & 269 \\
\hline & $\begin{array}{l}\text { Other expenditure (school furniture, } \\
\text { textbooks, etc.) }\end{array}$ & 115 & 1,008 & 1,061 & 842 \\
\hline & $\begin{array}{l}\text { Construction of classrocms for basic } \\
\text { education }\end{array}$ & 3,467 & 800 & 1,400 & 1,500 \\
\hline \multirow[t]{3}{*}{ First cycle of secondary school } & Construction of secondary schools & 2,393 & 700 & 1,020 & 1,100 \\
\hline & Recruitment of teachers & & 96 & 98 & 165 \\
\hline & Outfitting schools with student desks & 224 & 90 & 245 & 300 \\
\hline \multirow[t]{3}{*}{ Technical and professional education } & Construction and rehabilitation & 1,044 & 70 & 370 & 900 \\
\hline & Specialized equipinent & 1,112 & & - & 850 \\
\hline & Support fund & 238 & & 238 & 247 \\
\hline \multicolumn{6}{|l|}{ Program to improve quality: } \\
\hline \multirow[t]{4}{*}{ Basic } & $\begin{array}{l}\text { Rehabilitation and reconstruction of } \\
\text { classrooms }\end{array}$ & 2,023 & 75 & 275 & 750 \\
\hline & Outfitting schools with stadent desks & 187 & 700 & 115 & 220 \\
\hline & Procurement of pedagogical kits & 276 & 50 & 100 & 120 \\
\hline & In-service training of teachers & 886 & 250 & 560 & 700 \\
\hline \multirow{2}{*}{ First cycle of secondary school } & Rehabilitation of secondary schools & 628 & & 100 & 350 \\
\hline & $\begin{array}{l}\text { Other expenditure (school furniture, } \\
\text { textbooks, etc.) }\end{array}$ & 41 & 543 & 572 & 453 \\
\hline \multirow[t]{4}{*}{ Second cycle of secondary school } & Information technology & 23 & 80 & 115 & 220 \\
\hline & Laboratories & 80 & & 184 & 276 \\
\hline & Libraries & 80 & 50 & 125 & 188 \\
\hline & In-service training & 208 & 40 & 150 & 180 \\
\hline
\end{tabular}




\begin{tabular}{|c|c|c|c|c|c|}
\hline & & 200 & & 2003 & 2004 \\
\hline Priority areas & Priority actions & Proj. & Actual & Proj. & Proj. \\
\hline Technical and professional education & $\begin{array}{l}\text { Training the trainers } \\
\text { Training the trainers }\end{array}$ & 592 & & $\begin{array}{r}145 \\
50\end{array}$ & $\begin{array}{r}180 \\
54\end{array}$ \\
\hline $\begin{array}{l}\text { Modernization of the administration of } \\
\text { education }\end{array}$ & Institutional support & 2019 & 500 & 800 & 950 \\
\hline Health & & 7,448 & 5,784 & 7,154 & $\overline{7,458}$ \\
\hline $\begin{array}{l}\text { Broadening health care coverage and } \\
\text { increasing the access of the poor to health } \\
\text { services }\end{array}$ & $\begin{array}{l}\text { Constriction program (health posts and } \\
\text { health centers) }\end{array}$ & 1,538 & 1,310 & 2,875 & $2,84 \mathrm{i}$ \\
\hline & Equipment program & 1,342 & 1,248 & 548 & 548 \\
\hline & Rolling stock & 786 & 503 & 498 & 511 \\
\hline $\begin{array}{l}\text { Recuction of morbidity associated with } \\
\text { major diseases }\end{array}$ & STD/AIDS & 183 & 104 & 468 & 475 \\
\hline & Expanded vaccination program & 322 & 233 & 641 & 750 \\
\hline & $\begin{array}{l}\text { Malaria } \\
\text { Tuberculosis }\end{array}$ & $\begin{array}{r}120 \\
45\end{array}$ & $\begin{array}{l}58 \\
29\end{array}$ & $\begin{array}{l}391 \\
147\end{array}$ & $\begin{array}{l}427 \\
155\end{array}$ \\
\hline Protection of matemal and child health & $\begin{array}{l}\text { Reproductive health } \\
\text { PCIME }\end{array}$ & 454 & 237 & 350 & 470 \\
\hline Availability of medications & $\begin{array}{l}\text { CAMEC } \\
\text { Control laboratory }\end{array}$ & 97 & 55 & & \\
\hline $\begin{array}{l}\text { Strengthening capacities of central and } \\
\text { regional administrations }\end{array}$ & & $1,96 \mathrm{I}$ & 1565 & 987 & 951 \\
\hline Training centers & & 226 & 123 & 124 & 150 \\
\hline Information system & & 183 & 135 & 68 & 95 \\
\hline Safe drinking water and sanitation & & 1,482 & 610 & 2,125 & 2,939 . \\
\hline $\begin{array}{l}\text { Improved access to safe drinking water in } \\
\text { rural areas } \\
\text { Improved access to safe drinking water in } \\
\text { urban areas }\end{array}$ & $\begin{array}{l}50 \text { tube wells and } 10 \text { mini-systems per } \\
\text { year } \\
\text { Urban water systems, water points }\end{array}$ & $\begin{array}{l}802 \\
550\end{array}$ & 610 & 1,050 & $\begin{array}{l}1,610 \\
1,179\end{array}$ \\
\hline Water resources & $\begin{array}{l}\text { Study on improved management of } \\
\text { water resources } \\
\text { Study on water resources }\end{array}$ & $\begin{array}{l}\text { PM } \\
130\end{array}$ & PM & 152 & 150 \\
\hline Other services & $\begin{array}{l}\text { Establishment of the Universal Service } \\
\text { Access Agency }\end{array}$ & 500 & 110 & 500 & 4,353 \\
\hline Focus 4: 51 & trengthened governance and institution & & & & \\
\hline Governance & & 140 & 0 & 220 & 220 \\
\hline & $\begin{array}{l}\text { Strengthened capacities of NGOs and } \\
\text { grassoots commmity organizations } \\
\text { and their involvement in program } \\
\text { design and inplementation } \\
\text { Introduction of program budgets in the } \\
\text { remaining priority sectors (rura) } \\
\text { development, urban development, } \\
\text { water) } \\
\text { Support for Audit Office }\end{array}$ & PM & PM & PM & PM \\
\hline PRSP Information and Updating System & See Amex 2 & 150 & (0.) & 375 & 525 \\
\hline TOTAL & & 36,617 & 15,856 & 55,686 & 68,307 \\
\hline
\end{tabular}




\section{Annex 4: Medium-Term Macroeconomic Framework}

\begin{tabular}{|c|c|c|c|c|c|c|}
\hline & 2000 & 2001 & 2002 & 2003 & 2004 & 2005 \\
\hline \multicolumn{7}{|l|}{ Performance indicator } \\
\hline Annual growth rate & 5.2 & 4.0 & 33. & 5.4 & 6.1 & 6.0 \\
\hline Inflation rate & 3.3 & 4.7 & 40.010 & 6.4 & 3.7 & 3.5 \\
\hline Budget balance (in percent of GDP) & -4.4 & -5.5 & 6260 & -2.1 & -2.7 & -2.9 \\
\hline $\begin{array}{l}\text { Current balance, excluding official transfers and oil } \\
\text { (in percent of GDP) }\end{array}$ & -5.8 & -10.4 & 1.0 .6$. & -9.5 & -8.0 & -7.1 \\
\hline Gross reserves (in months of imports, excluding oil) & 6.9 & 6.8 & 87.7 & 7.2 & 6.4 & 6.0 \\
\hline \multicolumn{7}{|l|}{ Budget (in percent of GDP) } \\
\hline Government revenue & 25,3 & 20.6 & 326 : & 29.4 & 28.4 & 279 \\
\hline Expenditure and net lending & 29.7 & 26.1 & 315.0 & 31.6 & 31.1 & 30.8 \\
\hline Current & 17.2 & 16.9 & 198, & 19.3 & 19.1 & 18.6 \\
\hline Capital & 7.4 & 8.1 & 108. & 12 & 12 & 12.1 \\
\hline Education & 4.4 & 4.5 & 3. & 5.8 & 5.9 & 6.1 \\
\hline Health & 1.6 & 1.9 & 2.9. & 3,4 & 3.5 & 3.6 \\
\hline Balance of payments & & & 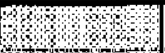 & & & \\
\hline Trade balance (in millions of U.S doliars) & 8.5 & -33.7 & 8. 7. & -130.7 & -132.7 & -145.2 \\
\hline Exports & 344.7 & 338.6 & 3303 & 341.2 & 367.5 & 392.9 \\
\hline Imports & 336.2 & 372.3 & 418 & 471.9 & 500.2 & 538.1 \\
\hline $\begin{array}{l}\text { Current balance, including official transfers and oil (in } \\
\text { percent of GDP) }\end{array}$ & -2.7 & -10.6 & 6.2. & -21.5 & -22.1 & -27.6 \\
\hline $\begin{array}{l}\text { Current balance, including official transfers but } \\
\text { excluding oil (in percent of GDP) }\end{array}$ & 0.8 & -2.7 & 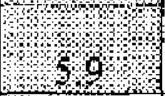 & -33 & -2.9 & -2.2 \\
\hline Overall balance (in millions of U.S. dollars) & 12.8 & -64.8 & 656 & -74.7 & -62.8 & -41.8 \\
\hline Memorandum items: & & & $\sqrt{2}$ & & & \\
\hline Nominal GDP (in billions of ouguiyas) & 229.4 & 251.3 & 269. & 296.4 & 325.6 & 356.9 \\
\hline Exctange rate (US\$ $/ \mathrm{UM}$ ) & 240.0 & 255.6 & 272111 & 268 & 272.7 & 278.2 \\
\hline Financing gap ${ }^{5}$ (in millions of U.S. dolfars) & 0.0 & 0.0 & 10 & 8.4 & 139.5 & 178.9 \\
\hline
\end{tabular}




\section{Annex 5: Revised Medium-Term Expenditure Framework for Education}

\begin{tabular}{|c|c|c|c|c|c|}
\hline & 2000 & 2001 & 2002 & 2003 & 2004 \\
\hline \multicolumn{6}{|l|}{ Major indicators } \\
\hline Rate of access to basic education & 93 & 97 & 111\% & 111 & 111 \\
\hline Retention ratio & 55 & $5 \mathrm{I}$ & $48 \%$ & 52 & 56 \\
\hline Gross enrollment ratio & 88 & 87 & $88 \%$ & 88 & 90 \\
\hline Rate of access to first cycle of secondary school ${ }^{6}$ & 25 & 28 & 26 & 26 & 28 \\
\hline \multicolumn{6}{|l|}{ Budget } \\
\hline Total expenditure (in millions of onguiygs) & 10,072 & 11,191 & 14800 & 17,114 & 19,359 \\
\hline Current & 8,320 & 8,692 & 09666 & 9,995 & 10,429 \\
\hline Capital & 1,752 & 2,499 & 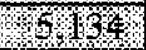 & 7,119 & 8,929 \\
\hline Administration & 330 & 328 & 362 & 495 & 437 \\
\hline Basic & 3,867 & 3,951 & 1.34 & 4,605 & 5,293 \\
\hline Secondary & 2,315 & 2,338 & 2788 & 2,892 & 2,847 \\
\hline Technical and professional & 324 & 337 & 420 & 350 & 356 \\
\hline Normal schools & 264 & 266 & $20 \%$ & 317 & 317 \\
\hline Higher & 1,219 & 1,471 & (1, $30 \%$ & 1,337 & 1,179 \\
\hline Expenditure (in percent of GDP) & 4,4 & 4.5 & 55 & 5.8 & 5.9 \\
\hline
\end{tabular}

\section{Annex 6: Revised Medium-Term Expenditure Framework for Health}

\begin{tabular}{|c|c|c|c|c|c|}
\hline & 2000 & 2001 & 2014 & 2003 & 2004 \\
\hline \multicolumn{6}{|l|}{ Performance indicator } \\
\hline Infant/child mortality ratio & 87 & & & & 80 \\
\hline Rate of DTC3 vaccination & 39.9 & 52 & 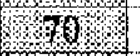 & 75 & 75 \\
\hline Proportion of assisted childbirths & 56.9 & & 160\% & 62 & 64 \\
\hline HIV prevalence rate & 0.5 & 0.5 & (2) & $<1$ & $<1$ \\
\hline Health expenditure burden, first quintile & 0.3 & 0.3 & (1) & $<0.3$ & $<0.3$ \\
\hline \multicolumn{6}{|l|}{ Budget } \\
\hline Total expenditure (in millions of ouguiyas) & 3624 & 4876 & 27 & 9953 & 11258 \\
\hline Current & 2500 & 2600 & 484 & 5429 & 6567 \\
\hline Capital & 1100 & 2300 & 200 & 4524 & 4691 \\
\hline P1. Availability of human resources & & & 145 & 1629 & 1970 \\
\hline P2. Geographical accessibility & & & 28 & 2171 & 1407 \\
\hline P3. Availability of material resources & & & 0.68 & 1085 & 1595 \\
\hline P4. Disease control and quality improvement & & & 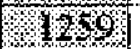 & 2171 & 3190 \\
\hline P5. Social action & & & \%94 & 1448 & 2064 \\
\hline P6. Institutional capacity building & & & 144 & 1448 & 1032 \\
\hline Health expenditure as a percentage of GDP & 1,6 & 2.0 & 2.91 & 3.4 & 3.5 \\
\hline
\end{tabular}




\section{Annex 7: MTEF for Urban Development}

\begin{tabular}{|c|c|c|c|}
\hline Programs (costs in millions of ouguiyas) & 2002 & 2003 & 2004 \\
\hline Pl. Institution building in the sector & 814 & 1681 & 459 \\
\hline Reforms & 316 & 1457 & 248 \\
\hline Building of execution capacity & 219 & 224 & 211 \\
\hline P2. Improvement of living conditions in cities in the interior & 3.49 & 4,602 & 2,344 \\
\hline P3. Improvement of living conditions in Nouakchott & 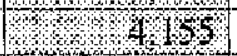 & 16,524 & 12,049 \\
\hline At-risk neighborhoods & 2068 & 3,512 & 1,150 \\
\hline Other infrastructure and equipment & $20 \%$ & 13,012 & 10,899 \\
\hline P4. Environment & 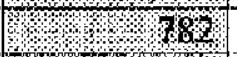 & 1121 & 1050 \\
\hline P5. Promotion of economic activities and employment & .48 & 674 & 174 \\
\hline Total & 1.261964 & 42,807 & 28,584 \\
\hline
\end{tabular}

\section{Annex 8: MTEF for Transportation Infrastructure}

\begin{tabular}{|c|c|c|c|c|c|}
\hline PROGRAMS (in millions of ouguiyas) & 2002. & 2003 & 2004 & 2005 & Total \\
\hline \multicolumn{6}{|l|}{ National roads, of which: } \\
\hline Magta Lahjar-Djouk & 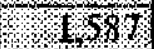 & 0 & 0 & 0 & 1,587 \\
\hline Djouk-Kiffa & $1 \times 27$ & 0 & 0 & 0 & 1,227 \\
\hline Nouakchott-Tiguent & 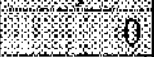 & 0 & 0 & 336 & 336 \\
\hline Tiguent-Rosso & (1) & 0 & 0 & 336 & 336 \\
\hline Boutilimit-Aleg & 2.60 & 0 & 0 & 306 & 306 \\
\hline Äroun-Kobeni-Nioro & 2. & 1,858 & 619 & 0 & 3,715 \\
\hline Rosso-Boghé & 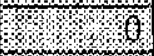 & 2,044 & 4,088 & 4,088 & 10,221 \\
\hline Nouakchott-Nouadhibou & 2.36 & 5,397 & 5,397 & 2,312 & 15,419 \\
\hline Kaédi-M'Bout-Sélibaby & 6 & 0 & 1,050 & 1,050 & 2,100 \\
\hline Atar-Kseirtorchane & 36) & 0 & 0 & 0 & 550 \\
\hline Sélibaby-Gouraye & , 0 & 0 & 180 & 180 & 360 \\
\hline Other national roads & 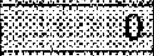 & 640 & 2,232 & 5,191 & 8,063 \\
\hline Regional and municipal roads & \% 82 & 1,462 & 1.962 & 2,251 & 6,467 \\
\hline Subtotal: Road infrastructure & 260 & 10,761 & 13,296 & 10,859 & 42,623 \\
\hline Port infrastructure & 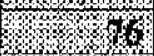 & 2,374 & 3,475 & 3,472 & 9,397 \\
\hline Airport infrastructure & 68 & 1,555 & 500 & 500 & 3,240 \\
\hline Repair and maintentance & $2 \% 3$ & 2,534 & 2,408 & 2,404 & 9,638 \\
\hline Capacity building and upgrading to standards & 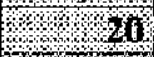 & 205 & 90 & 65 & 380 \\
\hline Subtotal for sector & 10780 & 17,429 & 19,769 & 17,300 & 65,278 \\
\hline Current budget of MET & 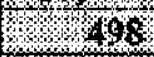 & 498 & -498 & 498 & 1,992 \\
\hline Total expenditure for sector & $142 \%$ & 17,927 & 20,267 & 17,798 & 67,270 \\
\hline
\end{tabular}




\section{Annex 9: Summary of Emergency Plan}

Following the drought that afflicted Mauritania in 2002, in November 2002 the government decided to trigger the regulatory mechanism for emergency assistance provided for under Decree 2002-17 of March 31, 2002. In consequence, an Interministerial Committee on Emergency Situations, representing all departments concemed by food security and assisted by a permanent coordination and monitoring unit, drew up an emergency plan for providing a rapid and multifaceted response to the situation facing the populations and herds in jeopardy.

\section{Components of the Plan}

This emergency plan revolves around four components:

- Food aid component;

- Health and nutrition component;

- Livestock feeding and watering and animal health component;

- Highly labor-intensive (HLI) rural and peri-urban program component.

\section{(1) Food aid component}

This program has two subcomponents: free distribution for the poorest, and subsidized sale prices. It will make it possible to cover the food requirements of a population of slightly over l million persons for a 10-month period (January-October 2003).

The free distribution subcomponent relates to 82,827 metric tons of cereal grains, 7,620 metric tons of legumes, and 3,810 metric tons of edible oil.

The subsidized sale component is UM 40 per kilogram of wheat.

\section{(2) Health and nutrition component}

The nutritional subcomponent will consist in opening community food centers (CACs) to improve the nutrition of children from birth to age 5. It will also focus on the opening and equipping of CRENs (Centers for Recovery and Nutritional Education) to handle senous malnutrition cases necessitating medical care as well as food.

This subcomponent will make it possible to serve 31,600 children among the $632 \mathrm{CACs}$ and 70 CRENs.

The health subcomponent will relate to making available a supply of medications necessary for the care of the people in at-risk areas ( 1 million persons).

\section{(3) Livestock component}

In this area there are three subcomponents: livestock feed, pastoral water supply, and animal health. 
kilogram). Of the total requirement of 127,000 metric tons, 40,000 metric tons should be purchased as the initial stock, with the amount used by its sale making it possible to purchase additional stocks in keeping with the rollover system.

The pastoral water supply subcomponent covers the following activities: drilling of 26 exploration tube wells, rehabilitation of 25 wells, and of 29 pumping stations.

Finally, the animal health subcomponent relates to:

- Epidemiological surveillance for the rapid detection of animal diseases, for which the risk of contagion is becoming higher because of the shrinkage in pasture areas;

- Systematic vaccination of the berd, by strengthening inter-regional or even interstate mobile veterinary teams.

\section{(4) Income generation component}

This program includes the three following subcomponents: construction or rehabilitation of urban and rural infrastructure, income-generating activities, and rural safety nets.

The infrastructure subcomponent covers the construction or rehabilitation of socioeconomic infrastructures (dikes, small dikes, wells, small water supply networks, public buildings, schools, health centers, public squares, urban improvement zones, sidewalks, reforestation zones, public parks, parking facilities, sanitation works, works of public utility in general, etc.).

The subcomponent on income-gener ating activities in nural and peri-urban areas will be oriented toward contributing to food security and to the satisfaction of basic nutritional requirements.

Finally, the rural safety nets component includes a small-scale grassroots livestock rearing program known as "Toumze" and a program for the production of dried meats intended for the most vulnerable population groups

\section{Operational modalities}

This emergency plan is implemented in the context of the institutional arrangements provided for under Decree No. 2002-17 of March 31, 2002 organizing emergency assistance. These are the interministerial committee on emergency situations, the standing monitoring and coordination unit, and the regional emergency units.

It is planned that each component will be implemented by the specialized national structure or by any other structures designated to that end by the interministerial committee.

In this context, implementation of the various subcomponents of the emergency plan has been distributed as follows:

(1) Food aid component: The free distribution and sales operations in rural municipalities are entrusted to the Food Security Commission (CSA), which will carry them out at all levels in close collaboration with representatives of the people. Sale at subsidized prices in the regional capitals is antristed in Snmimav 
their degree of vulnerability, Management of these centers in rural areas will be entrusted to local community structures under the supervision of the health services, and Centers for Recovery and Nutritional Education (CRENs) will be opened in public health centers. In the urban centers, CREN management may be carried out in collaboration with the NGOs active on the ground.

(3) Livestock component: In the context of the livestock feed subcomponent, it is planned to locate storage facilities at the wilaya, moughataa, and municipal capitals and on transhumance routes. The storage points will be determined by a commission chaired by the Administrative Authority and including, among others, the mayor with jurisdiction over the territory in question and representatives of professional organizations of stock farmers. Supervision of this component is entrusted to the CSA. Execution of the two other subcomponents (pastoral water supply and animal health) is entrusted to the Ministry of Water Resources and to the Ministry of Rural Development and Environment (MDRE).

(4) Income generation component: Execution of the subcomponents of this component is entrusted to the CDHLCPI, which will establishing decision making atrangements and management mechanisms with broad participation on the part of the administration, the municipalities, and the beneficiaries, depending upon the most appropriate participatory approach. These arrangements must be characterized by their effective decentralization and by the immediate availability of the funding necessary to make the weakly wage payments due. The subcomponents will strengthen local capacities for the execution, ownership, and full accountability for actions on the part of the beneficiaries.

The standing emergency unit will ensure the coordination, monitoring, and evaluation of all the components of the emergency plan, with assistance from the national structures concerned as well as support from outside experts in the event that proves worthwhile. It will also conduct periodic and systematic checks to ensure that the emergency assistance is effectively benefiting the target populations. On a monthly basis it will submit a detailed report to the interministerial committee on execution of the emergency plan.

\section{Overview of Emergency Plan Costs}

\begin{tabular}{|l|c|}
\hline COMPONENT & COST \\
\hline 1. Food aid component & \\
Free distribution & $4,905,220,275$ \\
Sale at subsidized prices & $2,040,000,000$ \\
Subtotal & $\mathbf{6 , 9 4 5 , 2 2 0 , 2 7 5}$ \\
\hline 2. Health and nutrition component & $821,958,496$ \\
Subtotal & $\mathbf{8 2 1 , 9 5 8 , 4 9 6}$ \\
\hline 3. Livestock component & $138,000,000$ \\
Animal health & $361,000,000$ \\
Pastoral water supply & $1,000,000,000$ \\
Animal feed & $\mathbf{1 , 4 9 9 , 0 0 0 , 0 0 0}$ \\
Subtotal & $1,000,000,000$ \\
\hline 4. Highly labor-intensive rural and peri-urban program & $\mathbf{1 , 0 0 0 , 0 0 0 , 0 0 0}$ \\
component & $300,000,000$ \\
Subtotal & $\mathbf{3 0 0 , 0 0 0 , 0 0 0}$ \\
\hline 5. Monitoring, supervision, and implementation component & $\mathbf{1 0 , 5 6 6 , 1 7 8 , 7 7 1}$ \\
Subtotal & \\
\hline GRAND TOTAL & \\
\hline
\end{tabular}

